\title{
The Danish Late Quaternary marine molluscs
}

The record of shell-bearing Danish Late Quaternary marine molluscs has been established on the basis of finds made during the systematic geological mapping since 1888, as presented in the publications from the Geological Survey of Denmark, mainly in the I. Række covering the descriptions for the map sheets. Furthermore, special papers on Holocene and Late Pleistocene marine molluscs have been included. Most of them have been listed in one of the preceding chapters on works on Danish sites with marine sediments.

1. The Bælt Sea area

2. The Baltic Sea area

3. The Kattegat area with fjords

4. The Limfjord area

5. The North Sea coastal area

6. The Vendsyssel area

7. The Skagen area

The regions are figured on the map (Fig. 2) and follow the outline of the geological map sheets except the Skagen area. It should be especially noted that the southern limit during the Holocene of the North Sea coastal region is at Blåvands Huk. Although this area from Varde to the German border has been mapped, no descriptions have been published. However, studies of the Eemian from this region have been published and will be commented upon when presenting the Eemian records from the above-mentioned areas.

The Bælt Sea area has been taken as the region between the Kattegat region and the Baltic, here following Ekman (1953) saying that the boundary between the Bælt Sea and the Baltic proper is the threshold between Gedser and Darss and the southern end of the Øresund, see Fig. 1.

The reason for including the Øresund north of Saltholm (northern and middle Øresund sensu Jensen \& Knudsen 1995) in the Kattegat region is that regarding the water from the Baltic the Øresund is a sound a passage - for the brackish water flowing north, but regarding the salt-water from the Kattegat, the Øresund is a fjord down to the threshold between Amager and Limhamn, to quote Thorson (1944a, p. 42).

The subfossil shell-bearing molluscs are presented on the background of the annotated check list of recent marine molluscs of Danish waters by Jensen \&
Knudsen (1995). Furthermore, general information has been taken from Jensen \& Spärck (1934), Lemche (1948), Nordsieck (1968, 1969), Fretter \& Graham (1976-1978, 1980-1982, 1984), Fretter et al. (1986) and Poppe \& Goto $(1991,1993$ ) (which will not be quoted throughout the text, listing the many species and their environment).

Only the synonyms mentioned in texts on Danish molluscan finds are included. A list of these synonyms is found heading the Index of species.

The investigations carried out by scientists in the northern Atlantic have given a good base for the evaluation of the Danish Late Quaternary molluscan fauna. These studies have been published mainly in papers on the Zoology of East Greenland, The Godthaab Expedition 1928, the Zoology of Iceland, and the Zoology of the Faroes. However, the Zoology of Greenland has been supplemented by contributions from Macpherson (1971), Lubinsky (1980), the 6.og 7. Thule Expedition til Sydøstgrønland 1931-33 under the leadership of Knud Rasmussen and the Treaarsexpeditionen til Christian den X's Land 1931-34 under the leadership of Lauge Koch.

In the two last-mentioned contributions, especially the animal ecology and the Arctic communities have been treated, which form a very important part in the discussion of the Danish Late Quaternary molluscan assemblages. The following publications on molluscs can be mentioned:

1. From Greenland: Spärck (1933), Thorson (1933, 1944b, 1951), Thorson \& Ussing (1934), Madsen (1936), Bertelsen (1937), Lemche (1941a, b), Ockelmann (1958), Kramp (1961, 1963).

2. From Iceland: Spärck (1937), Lemche (1938), Thorson (1941), Knudsen (1949a, b), Madsen (1949).

3. From the Faeroes: Lemche (1928), Thorson \& Spärck (1928), Spärck \& Thorson (1931), Petersen (1968), Knudsen (1970).

As to the community concept as worked out by C.G.J. Petersen, references have already been given to Petersen \& Jensen (1911), Petersen (1913, 1914, 1915, 1918), and Thorson (1957). The regional division of the Northern European seas in to Arctic, Subarctic, Boreal and Lusitanian is from the zoogeographical division of the 
northern European seas as given by Feyling-Hanssen (1955, fig. 5) and Símonarson et al. (1998), as seen on Figs 4 and 5 respectively.

The molluscan genera and species are presented in groups within Class, Subclass and Order mainly following the presentation of recent marine molluscs of Danish waters as given by Jensen \& Knudsen (1995). When there is no subfossil record at hand the information is taken from the recent data as given by Poppe \& Goto (1991, 1993), Jensen \& Knudsen (1995) and others as listed previously. To facilitate the use of the index of all molluscan species, a list of synonyms is given as mentioned earlier including the species mentioned in Danish mollusc literature.

\section{Class Polyplacophora Order Neoloricata}

Among the seven species recorded in the recent Danish fauna only one, Tonicella marmorea, has been found subfossil in the Vendsyssel area from the Younger Weichselian deposits. It is a circumBoreal species which in Europe is known from northern Scandinavia south to Denmark and recorded from around Iceland (Knudsen 1949a, b) down to Ireland (Poppe \& Goto 1991). It is common in Danish waters, being known from the central part of the Kattegat and the Øresund region (Muus 1959), e.g. Subarctic-Boreal-Lusitanian species.

Habitat. Common in shallow water of less than $20 \mathrm{~m}$, otherwise recorded from 0-183 m (Muus 1959).

The lack of information on subfossil finds may reflect difficulty in determination when the species is found in the subfossil state of preservation with the shell parts apart. Polyplacophora do occur as seen from the Skagen Well where finds have been recognised at the $70.10-70.30 \mathrm{~m}$ and the 37.0-37.25 m levels, viz. during the Subboreal and the Subatlantic respectively.

Among the other - only recent - finds of Polyplacophora, Leptochiton asellus is widely found from the Arctic to the Lusitanian. Hanleya hanleyi, Ischnochiton albus and the above-mentioned Tonicella marmorea are all found in the Subarctic, Boreal and Lusitanian regions. The last three species, Callochiton septemvalvis, Lepidochitona cinereus and Tonicella rubra, are all restricted to the Boreal-Lusitanian region.
Fig. 6. Scissurella crispata Fleming 1828. Anholt II, 78.06-78.09 m b.s. $\times 20$. MGUH 25316 .

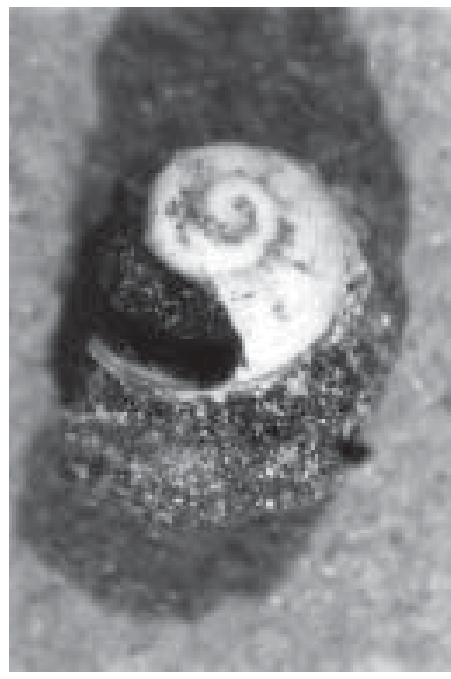

\section{Class Gastropoda Subclass Prosobranchia Order Archaeogastropoda}

\section{Scissurella crispata Fleming 1828}

Fig. 6

Distribution. W Greenland, S and W Iceland, Spitsbergen, Norway north of Lofoten, and south to the Mediterranean.

Occurrence. The Subarctic (not in true Arctic water), Boreal and Lusitanian regions (according to Thorson 1941).

Habitat. In the waters around Iceland (Thorson 1941, p. 4), the living specimens have often been found at depths greater than $500 \mathrm{~m}$ on clay bottom. However, Poppe \& Goto (1991, p. 64) write that the species lives on stones, shelly sand and clay bottoms between 15 and 600 m. Fretter \& Graham (1976, pp. 2-4) stated that the species is always sublittoral, even in the extreme northerly limits of its range, and occurs from 8$2000 \mathrm{~m}$. It is not recorded from Danish waters although Fretter \& Graham mentioned it from the Norwegian and Swedish coasts of the Skagerrak.

Only subfossil finds. During the Eemian in the Kattegat region. 


\section{Patella vulgata Linnaeus 1758}

Distribution. Faeroes, Norway off the Lofoten islands, and south to the Straits of Gibraltar (Thorson 1941).

Occurrence. Boreal-Lusitanian.

Habitat. Intertidal, rocky shores or man-made hard substrates. However, it also occurs with seaweed. Only one recent individual has been found at Løkken, while empty shells are often found on the Skagerrak coast (Knudsen 1993).

Subfossil finds. The Limfjord region, Holocene, in a 'køkkenmødding' (kitchen midden) at Bulbjerg (Petersen 1888).

\section{Helcion pellucidum (Linnaeus 1758)}

Distribution. West and South Iceland, northern Norway north of Lofoten, and south to Portugal (Thorson 1941). Also found in the Øresund, but absent from the Baltic and the Limfjord.

Occurrence. Boreal and Lusitanian.

Habitat. Lives on seaweeds at depths from 0 to $27 \mathrm{~m}$. Petersen (1888) points to this habitat as a reason why it is rarely found.

Subfossil finds. The Limfjord region and Vendsyssel, Holocene.

\section{Lepeta caeca (Müller 1776)}

Distribution. From northern Scandinavia, N and S Iceland and Spitsbergen (Thorson 1941) south to Scotland. It is not present in the Baltic, the North Sea and the Channel, but occurs in the Azores. This species, according to Poppe \& Goto (1991), prefers cold temperatures and lives at greater depths in the southern part of its range. In this way it exemplifies the tropical submerge. It is present in the Øresund region and has been reported from single finds in the Kattegat (Petersen 1888).

Occurrence. Subarctic and Boreal.

Subfossil finds. None.

\section{Iotbia fulva (Müller 1776)}

Distribution. Northern Scandinavia and S and W Iceland south to the Irish Sea, and like Lepeta caeca in deep water off the Azores. It is found in the Øresund region, but with rare and single finds in the Kattegat (Petersen 1888).

Occurrence. Boreal and Lusitanian.

Habitat. Offshore between 5 and $600 \mathrm{~m}$ on hard substrates like Lepeta caeca.

Subfossil finds. The Limfjord region, Holocene.

\section{Acmaea tessulata (Müller 1776)}

Distribution. East Greenland, around Iceland (Thorson 1941) and in Scandinavia according to Petersen (1888). The Limfjord (Petersen 1986a). Common in the Øresund, but absent in the Baltic. Extends southwards to the north of the British Isles and Northern Ireland.

Occurrence. Arctic, Subarctic, Boreal, and Lusitanian.

Habitat. Lower part of the intertidal zone. In the south connected with Zostera.

Subfossil finds. The Limfjord region, Holocene.

\section{Acmaea virginea (Müller 1776)}

Distribution. Northern Scandinavia and around Iceland (Thorson 1941), south to the Cape Verde Islands. Common in the Kattegat and Øresund, but not found in the Baltic.

Occurrence. Subarctic, Boreal, Lusitanian.

Habitat. On hard substrate at depths from 0 to $100 \mathrm{~m}$.

Subfossil finds. The Limfjord and Vendsyssel regions, Holocene.

\section{Emarginula fissura (Linnaeus 1758)}

Distribution. Scandinavia and south to the Mediterranean, according to Petersen (1888) taken alive from the Øresund, dead shells in the northern Kattegat. 
Occurrence. Boreal and Lusitanian.

Habitat. From the low tide line to a depth of $700 \mathrm{~m}$ on hard substrate.

Subfossil finds. None.

\section{Puncturella noachina (Linnaeus 1771)}

Distribution. Spitsbergen and around Iceland (Thorson 1941), Scandinavia south to Portugal. Also found in the Skagerrak and Kattegat including Øresund.

Occurrence. Arctic, Subarctic, Boreal and Lusitanian.

Habitat. Between 10 and $200 \mathrm{~m}$ on rock and stones.

Subfossil finds. None.

\section{Margarites belicinus (Phipps 1774)}

Distribution. From northern Scandinavia, Spitsbergen and around Iceland (Thorson 1951) south to the British Isles. A few records from the Skagerrak and Kattegat.

Occurrence. Arctic, Subarctic, Boreal and northern part of the Lusitanian region.

Habitat. From the intertidal zone to $400 \mathrm{~m}$ deep on seaweeds and under stones.

Subfossil finds. The Limfjord region, Holocene.

\section{Gibbula cineraria (Linnaeus 1758)}

Distribution. From northern Scandinavia north of Lofoten, and W and S Iceland (Thorson 1941) south to Morocco. According to Petersen (1888) known from the Kattegat including Øresund, the Bælt Sea and the Limfjord area.

Occurrence. Boreal-Lusitanian.

Habitat. Intertidal to $130 \mathrm{~m}$ deep on rocks and seaweeds.

Subfossil finds. The Limfjord, the North Sea and Vendsyssel, Holocene. Recorded from the North Sea during the Eemian.
Gibbula tumida (Montagu 1803)

Distribution. From northern Norway north of Lofoten, and S and W Iceland (Thorson 1941), south to Spain. Known from the Kattegat, including the Øresund, but not so common as Gibbula cineraria. The species does not occur in the Limfjord (Petersen 1986a, table 1).

Occurrence. Boreal-Lusitanian.

Habitat. On gravel bottoms from below low tide to depths of $1200 \mathrm{~m}$.

Subfossil finds. The Limfjord and Vendsyssel area, Holocene.

\section{Jujubinus clelandi (W. Wood 1828)}

Distribution. From the Lofoten Islands south into the Mediterranean. Found in the Kattegat region, including the Øresund, but rare.

Occurrence. Boreal-Lusitanian.

Habitat. On various types of bottom from depths of $35 \mathrm{~m}$ to $800 \mathrm{~m}$.

Subfossil finds. None.

\section{Calliostoma formosa (Mighels 1842)}

Distribution. Along the Norwegian coast, W and S Iceland (Thorson 1941), and south to the British Isles but not on the west side.

Occurrence. Boreal.

Habitat. Dredged at depths between 19 and $1000 \mathrm{~m}-$ the species is never littoral.

Subfossil finds. None.

Calliostoma zizyphinum (Linnaeus 1758)

Distribution. From the Lofoten islands south to the Azores. In the Skagerrak.

Occurrence. Boreal-Lusitanian. 
Habitat. Intertidal to $300 \mathrm{~m}$ deep - lives on all types of bottoms.

Subfossil finds. None.

\section{Skenea serpuloides (Montagu 1808)}

Distribution. From the British Isles south to Portugal and into the Mediterranean.

Occurrence. Lusitanian.

Habitat. From the intertidal zone down to $50 \mathrm{~m}$ deep. Intertidal on weeds and stones, and sublittoral dredged from shelly and gravelly sand.

Only subfossil finds. The Limfjord area, Holocene.

\section{Skenea basistriata (Jeffreys 1877)}

Distribution. Atlantic coast of Europe, but not in the North Sea and the Baltic.

Occurrence. Boreal-Lusitanian.

Habitat. On soft bottom - never in shallow water or littoral sequences, deep water 90-2400 m.

Subfossil finds. The Limfjord region, Holocene.

\section{Theodoxus fluviatilis (Linnaeus 1758)}

Distribution. From the Pyrenees and the British Isles east towards the Caucasus, including northern Sweden and the coasts of Finland.

Occurrence. Lusitanian-Boreal.

Habitat. The primary habitat of this species is rivers. In the Baltic Sea the form littoralis becomes a common littoral animal (Fretter \& Graham 1978a, p. 105). The species is also recorded from the fjords bordering the Kattegat region today.

Subfossil finds. The Kattegat and Limfjord regions, Holocene.

The Archaeogastropoda are represented by 16 species in the recent marine fauna, out of which ten have been recorded from the past. Only two species, Skenea serpuloides and Scissurella crispata, are not found in the recent fauna. There is a total number of subfossil finds among the Archaeogastropoda of 12 species, with two from the Eemian and ten from the Holocene.

\section{Order Mesogastropoda}

\section{Littorina littorea (Linnaeus 1758)}

Distribution. From northern Norway north of Lofoten, and south to Spain. Common along all the Danish coasts but not in the Baltic and on the more exposed sandy coasts (Petersen 1888). Recent records from the Baltic as far as Bornholm (Fretter \& Graham 1980, p. 256).

Occurrence. Boreal and Lusitanian.

Habitat. The intertidal zone, abundant on rocky shores, might be found to a depth of $60 \mathrm{~m}$.

Subfossil finds. The Bælt Sea, Baltic, Kattegat, Limfjord, the North Sea and Vendsyssel regions, Holocene. The Bælt Sea, Baltic, Kattegat and North Sea regions in the Eemian.

Melaraphe (Littorina) neritoides (Linnaeus 1758)

Distribution. From western Norway south to Morocco and the Mediterranean. A scattered occurrence in the Kattegat (Jensen \& Knudsen 1995). The species is recorded from the Limfjord (Petersen 1986a).

Occurrence. Boreal and Lusitanian.

Habitat. Lives high on the rocky shores (splash zone).

Subfossil finds. None.

\section{Littorina mariae Sacchi \& Rastelli 1966}

Distribution. From northern Scandinavia south to the Mediterranean, extending through the Kattegat into the Bælt Sea.

Occurrence. The Boreal and Lusitanian.

Habitat. In the tidal zone on weeds.

Subfossil finds. None. (The species may have been confused with Littorina obtusata.) 


\section{Littorina obtusata (Linnaeus 1758)}

Distribution. W Greenland, S and W Iceland (Thorson 1941), northern Scandinavia north of Lofoten, and south to the Mediterranean. The species extends through the Limfjord and Kattegat into the Bælt Sea (Fretter \& Graham 1980).

Occurrence. Subarctic, Boreal and Lusitanian.

Habitat. Intertidal, lives on weeds.

Subfossil finds. The Bælt Sea, Kattegat, Limfjord, North Sea and Vendsyssel regions, Holocene. During the Eemian recorded from the North Sea.

\section{Littorina saxatilis (Olivi 1792)}

Distribution. From Greenland, Spitsbergen, around Iceland and the Atlantic coasts of Europe. Common in the fjords bordering the Kattegat, including the Limfjord (Petersen 1986a).

Occurrence. The Arctic, Subarctic, Boreal and Lusitanian.

Habitat. Intertidal.

Subfossil finds. The Bælt Sea, Kattegat, Limfjord, North Sea and Vendsyssel regions, Holocene. The North Sea during the Eemian, and the Vendsyssel area in the Late Weichselian.

\section{Littorina tenebrosa (Montagu 1803)}

Distribution. Off southern Iceland and the Atlantic coasts of Europe. The species is found in the Limfjord, and penetrates also into the Baltic, with finds off Møn and Stevns (Petersen 1888).
Occurrence. The Boreal and Lusitanian.

Habitat. Intertidal.

Subfossil finds. The Bælt Sea, Baltic, Kattegat, Limfjord and Vendsyssel regions, Holocene.

\section{Lacuna pallidula (da Costa 1778)}

Fig. $7 \mathrm{a}, \mathrm{b}$

Distribution. From Spitsbergen, around Iceland and along the Atlantic coast down to the Gulf of Biscay. Enters the Danish waters, including the Limfjord, the Øresund and the Brelt Sea.

Occurrence. The Arctic, Subarctic, Boreal and Lusitanian.

Habitat. Intertidal to $70 \mathrm{~m}$ deep on weeds.

Subfossil finds. The Bælt Sea, Limfjord, North Sea and Vendsyssel regions, Holocene. In the Skagen Well from the Subatlantic.

\section{Lacuna crassior (Montagu 1803)}

Distribution. From the Arctic Seas to the British Isles. Only records from the North Sea and from the NW coast of Sweden.

Occurrence. The Arctic, Subarctic and Boreal.

Habitat. Sublittoral to $90 \mathrm{~m}$ deep on soft bottoms with stones and shells (Fretter \& Graham 1980, p. 248).

Subfossil finds. None.
Fig. 7. a, b: Lacuna pallidula (da Costa 1778). Skagen $4,30.8$ $30.5 \mathrm{~m}$ b.s., lab. no. 355,93. $\times$ 20. MGUH 25317.
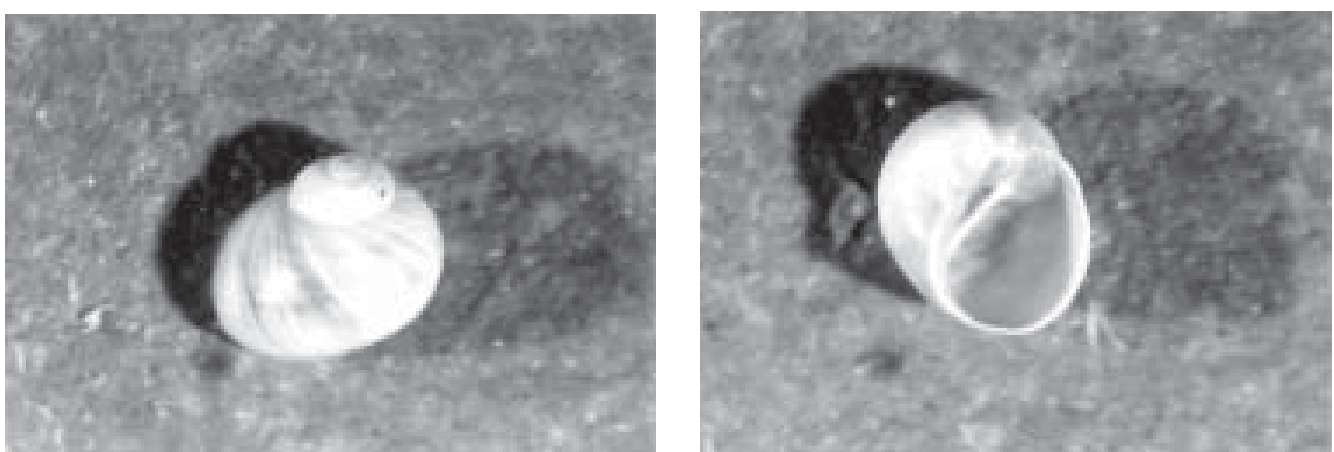


\section{Lacuna parva (Montagu 1803)}

Distribution. From Norway off the Lofoten, and south to Spain, found in the Kattegat region with fjords, but few records, and not found in the Limfjord.

Occurrence. Boreal and Lusitanian.

Habitat. Intertidal extending sublittorally to around $50 \mathrm{~m}$ as Lacuna vincta (Fretter \& Graham 1980, p. 250) and living on seaweeds.

Subfossil finds. The Limfjord, North Sea and Vendsyssel regions, Holocene. From the North Sea during the Eemian.

\section{Lacuna vincta (Montagu 1803)}

Distribution. From W Greenland around Iceland, Norway and south to Spain. In the Danish waters, including the Limfjord, found into the Bælt Sea (Fretter \& Graham 1980).

Occurrence. Subarctic, Boreal and Lusitanian.

Habitat. Intertidal to $60 \mathrm{~m}$ deep living on seaweeds.

Subfossil finds. The Bælt Sea, Kattegat, Limfjord, North Sea and Vendsyssel regions, Holocene. In the North Sea region found during the Eemian. In the Vendsyssel area recorded from the Eemian, and also from the Early/Middle and Late Weichselian (Older and Younger Yoldia Sea respectively).

\section{Hydrobia neglecta Muus 1963}

Distribution. The British Isles, Ireland and the North Sea.

Occurrence. Boreal and Lusitanian.

Habitat. Shallow-water environments on the soft substratum or the vegetation.

Subfossil finds. None.

\section{Hydrobia ulvae (Pennant 1777)}

Fig. 8

Distribution. Norway off Lofoten south to the Mediterranean. In all the Danish waters including the Baltic.

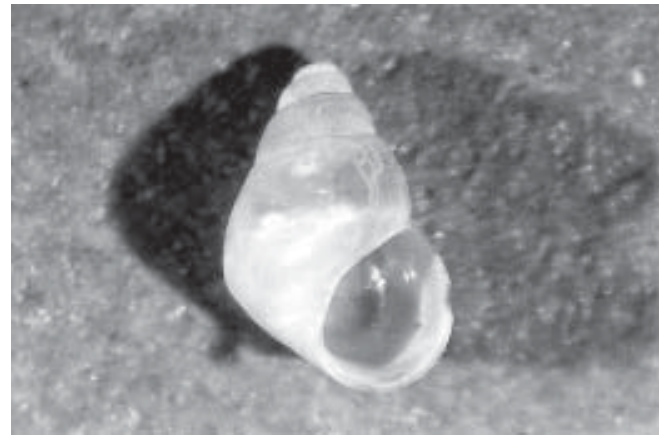

Fig. 8. Hydrobia ulvae (Pennant 1777). Skagen 4, 25.0-25.5 m b.s., lab. no. 350,93. × 20. MGUH 25318.

Occurrence. The Boreal and Lusitanian.

Habitat. The intertidal zone, but has been found as deep as $20 \mathrm{~m}$, on soft substrate, most often on intertidal banks of firm mud or muddy sand (Fretter \& Graham 1978a, p. 122).

Subfossil finds. The Bælt Sea, Baltic, Kattegat, Limfjord, North Sea and Vendsyssel regions, Holocene. In the Skagen Well from the Subatlantic. During the Eemian recorded from the Bælt Sea, Baltic, Kattegat and the North Sea regions.

\section{Hydrobia ventrosa (Montagu 1803)}

Distribution. Norway off Lofoten, south to the Mediterranean. In all the Danish waters including the Baltic.

Occurrence. The Boreal and Lusitanian regions.

Habitat. The intertidal zone, on soft substratum like $H y$ drobia ulvae, but prefers lower salinities (Fretter \& Graham 1978a, p. 126). The two species may occur together, so quantitative analyses must be undertaken to designate any changes in the environment (Petersen 1993).

Subfossil finds. The Baltic, Kattegat, Limfjord and the North Sea regions, Holocene.

\section{Potamopyrgus antipodarum (Gray 1853)}

Distribution. From Scandinavia to Spain and in Danish waters into the Baltic, a late immigrant according to Jensen \& Knudsen (1995).

Occurrence. The Boreal and Lusitanian regions. 
Habitats. In all kinds of brackish and freshwater habitats. Much like the distribution of Hydrobia ventrosa in brackish waters (Fretter \& Graham 1978a, p. 132).

Subfossil finds. None.

\section{Skeneopsis planorbis (Fabricius 1780)}

Distribution. W Greenland, around Iceland and Norway, south to the Mediterranean. Known from few places in Danish waters.

Occurrence. The Subarctic, Boreal and Lusitanian regions.

Habitat. Intertidal down to a depth of $70 \mathrm{~m}$, lives on seaweeds.

Only subfossil finds. The Limfjord and the Vendsyssel regions, Holocene.

\section{Barleeia unifasciata (Montagu 1803)}

Fig. 9

Distribution. From the Shetlands south into the Mediterranean.

Occurrence. The Boreal and Lusitanian regions.

Habitat. Shallow waters, intertidal, lives on seaweeds on rocky shores.

Only subfossil finds. The Skagen Well from the Subatlantic.

\section{Alvania abyssicola (Forbes 1850)}

Distribution. From northern Norway to the Mediterranean. The species extends into the Skagerrak and Kattegat, including the Øresund.

Occurrence. The Boreal and Lusitanian regions.

Habitat. On muddy bottom in sublittoral areas at depths of $15-100 \mathrm{~m}$.

Subfossil finds. The Vendsyssel area from the Eemian.

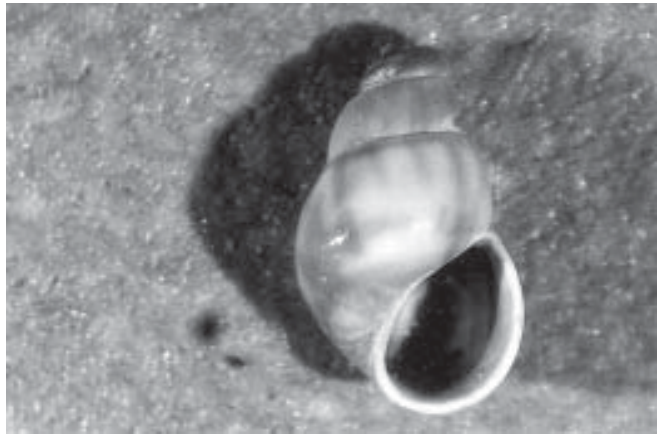

Fig. 9. Barleeia unifasciata (Montagu 1803). Skagen 3, 33.9034.20 m b.s., lab. no. 709,93. × 20. MGUH 25319.

\section{Alvania jeffreysi (Waller 1864)}

Distribution. S and W Iceland, Norway, south to the Mediterranean. Found in the Skagerrak, but not in the North Sea.

Occurrence. The Boreal and Lusitanian regions.

Habitat. Always sublittoral from 50 to 600 m on sandy bottom.

Subfossil finds. None.

\section{Alvania lactea (Michaud 1830)}

Distribution. From the Channel Islands south to Morocco and the Mediterranean.

Occurrence. The Lusitanian region.

Habitat. Sublittorally under stones and amongst algae.

Only subfossil finds. The Limfjord and Vendsyssel areas, Holocene.

\section{Alvania cimicoides (Forbes 1844)}

Distribution. SW and NW Iceland (empty shells), Norway, north of Lofoten, and south to the Mediterranean; probably absent from the Channel and the North Sea.

Occurrence. The Boreal and Lusitanian regions.

Habitat. Sublittoral, from the laminarian zone downwards, but mainly in deeper water down to $500 \mathrm{~m}$. 
Usually found on soft bottoms (Fretter \& Graham 1978b).

Only subfossil finds. The Vendsyssel area, Holocene.

\section{Alvania punctura (Montagu 1803)}

Distribution. Norway south of Lofoten (including Lofoten) and south to the Mediterranean. It extends to the Swedish west coast, but is absent from the Øresund, the Baltic, the eastern shores of the North Sea and the eastern basin of the Channel (Fretter \& Graham 1978b). However, according to Jensen \& Knudsen (1995) Alvania punctura is found in the northern and central parts of the Øresund.

Occurrence. The Boreal and Lusitanian regions.

Habitat. Sublittoral to depths of c. 100 m, on both finer and coarser substrata.

Subfossil finds. The Limfjord and the Vendsyssel regions, Holocene.

\section{Alvania cruenta Odhner 1915}

Distribution. Arctic Canada, West Greenland and Svalbard (Thorson 1951; Macpherson 1971).

Occurrence. The Arctic and Subarctic.

Habitat. From 19 to 234-254 m on mud (Macpherson 1971).

Only subfossil finds. The Early/Middle Weichselian in the Vendsyssel region.

\section{Alvania jan mayeni (Friele 1886)}

Distribution. E and W Greenland, Spitsbergen, NE Iceland, and Norway north of Lofoten (Thorson 1941).

Occurrence. The Arctic and Subarctic with Boreal outposts.

Habitat. Off Iceland between 94-442 $\mathrm{m}$ in deep on clay with many stones (Thorson 1941).

Only subfossil finds. The Early/Middle Weichselian (Older Yoldia Clay) in Vendsyssel.

\section{Alvania scrobiculata (Möller 1842)}

Distribution. E and W Greenland, Spitsbergen, N and E Iceland, and Norway north of Lofoten (Thorson 1941).

Occurrence. The Arctic and Subarctic with Boreal outposts.

Habitat. From $22 \mathrm{~m}$ at E Greenland to $342 \mathrm{~m}$ in the northern Arctic Sea on a bottom of sand and with algae (Thorson 1941).

Only subfossil finds. From the Early/Middle Weichselian (Older Yoldia Clay) in Vendsyssel.

\section{Cingula semistriata (Montagu 1808)}

Distribution. From Lofoten and south along the West coast of Norway to the Mediterranean (rare in the north). It extends into the Kattegat, but is absent from the eastern shores of the southern North Sea and the Limfjord.

Occurrence. The Boreal and Lusitanian regions.

Habitat. On rocky shores in the intertidal zone and sublittorally to $100 \mathrm{~m}$, fond of silty places (Fretter \& Graham 1978b).

Subfossil finds. The Limfjord and the Vendsyssel areas, Holocene.

\section{Cingula turgida (Jeffreys 1870)}

Distribution. From Norway north of Lofoten to the south into Kattegat.

Occurrence. The Boreal region.

Habitat. On muddy bottoms down to c. $1000 \mathrm{~m}$. Subfossil finds. The North Sea region, Holocene.

\section{Obtusella alderi (Jeffreys 1858)}

Distribution. From Norway to Spain, not on the eastern shores of the North Sea and in the Baltic; however, found in the Kattegat, including the northern part of the Øresund.

Occurrence. The Boreal and Lusitanian regions. 
Habitat. Sublittoral to a depth of $60 \mathrm{~m}$ amongst algae and on sandy or gravelly bottoms.

Subfossil finds. None.

\section{Onoba aculeus (Gould 1841)}

Distribution. From Spitsbergen, W Greenland, around Iceland and along the coast of Norway into the Kattegat, including the Øresund. Also found at localities off Ireland.

Occurrence. The Arctic, Subarctic, Boreal and Lusitanian regions.

Habitat. Found to about $200 \mathrm{~m}$ on algae.

Subfossil finds. None.

\section{Onoba semicostata (Montagu 1803)}

Distribution. Around Iceland, along the coast of Norway and south to the Mediterranean. Absent from the eastern North Sea coasts, but extends through the Limfjord and Kattegat, including the Øresund, into the Bælt Sea and the most saline parts of the Baltic (Fretter \& Graham 1978b).

Occurrence. The Subarctic, Boreal and Lusitanian regions.

Habitat. From the intertidal region to depths of $100 \mathrm{~m}$. Found under stones, amongst weeds, mussels and tunicates in shelly gravel, but only where there are quantities of silt (Fretter \& Graham 1978b).

Subfossil finds. The Bælt Sea, Kattegat, Limfjord and Vendsyssel regions, Holocene.

\section{Onoba proxima (Forbes \& Hanley 1850)}

Distribution. From the western coast of Britain south to the Mediterranean.

Occurrence. The Lusitanian region.

Habitat. From 10 to 170 m on bottoms of muddy sand.

Only subfossil finds. The Limfjord region, Holocene.

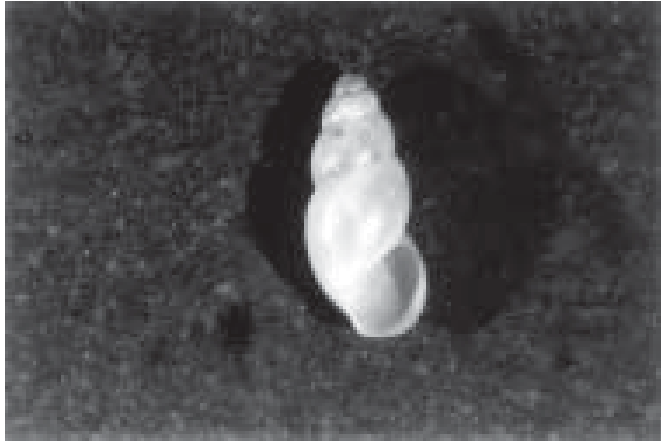

Fig. 10. Onoba vitrea (Montagu 1803). Skagen 3, 67.0-67.25 m b.s., lab. no. 720,93. × 9.6. MGUH 25320.

\section{Onoba vitrea (Montagu 1803)}

Fig. 10

Distribution. From Norway off Lofoten and south to the Mediterranean, extends through Skagerrak into the Kattegat, including the Øresund, but absent from the Limfjord.

Occurrence. The Boreal and Lusitanian regions.

Habitat. Muddy bottoms at depths of 10-50 $\mathrm{m}$ in the northern parts of its range, but extending to $120 \mathrm{~m}$ in the south. Further notes on Onoba species in Fretter \& Graham (1978b, p. 170).

Subfossil finds. The Kattegat, Limfjord, North Sea, Vendsyssel and Skagen areas, Holocene. In the Skagen Well recorded from the Atlantic, the Subboreal and the Subatlantic. During the Eemian recorded from the North Sea.

\section{Rissoa albella Lovén 1846}

Fig. 11

Distribution. From Norway off the Lofoten islands, and south to the Mediterranean, extending into the Limfjord and the Kattegat with the Danish fjords, including the Øresund and the Brelt Sea.

Occurrence. The Boreal and Lusitanian regions.

Habitat. On rocky shores amongst weeds, sublittoral to $15 \mathrm{~m}$. It is tolerant of some brackishness (Fretter \& Graham 1978b).

Subfossil finds. The Bælt Sea, Baltic, Kattegat, Limfjord, North Sea, Vendsyssel and Skagen Well from the Sub- 


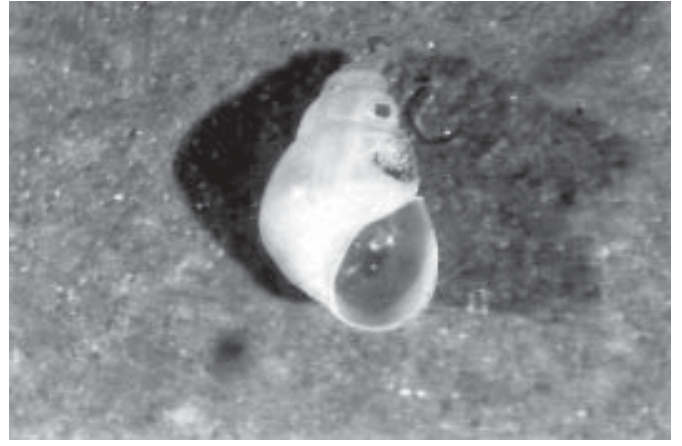

Fig. 11. Rissoa albella Lovén 1846. Skagen 4, 30.0-30.5 m b.s., lab. no. 355,93. × 20. MGUH 25321.

atlantic, Holocene. From the Eemian recorded from the North Sea.

\section{Rissoa inconspicua Alder 1844}

Distribution. From northern Norway, north of Lofoten, and south to the Mediterranean. Occurring in the Limfjord, Øresund and Bælt Sea.

Occurrence. The Boreal and Lusitanian regions. Fretter \& Graham (1978b, p. 200) indicate that the species is found to the Arctic. However, it is not recorded from Iceland and the Faroes but only from Norway north of Lofoten (Thorson 1941, table II, p. 141).

Habitat. Typically sublittoral living on algae, and on sandy gravel to depths of about $100 \mathrm{~m}$. Tolerant of slightly brackish conditions.

Subfossil finds. The Bælt Sea, Baltic, Kattegat, Limfjord, North Sea and Vendsyssel, Holocene. During the Eemian recorded from the Brelt Sea, Kattegat and North Sea regions.

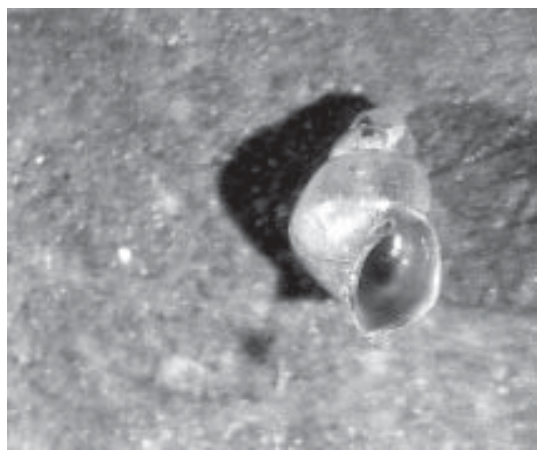

Fig. 12. Rissoa violacea Desmarest 1814 . Skagen 4, 27.0$27.5 \mathrm{~m}$ b.s., lab. no. $352,93 . \times 20$ MGUH 25322.

\section{Rissoa membranacea (J. Adams 1800)}

Distribution. From Norway off Lofoten and south to the Canary Islands. Extends into the Limfjord, Kattegat, Bælt Sea and the westernmost part of the Baltic (the Rügen Island).

Occurrence. The Boreal and Lusitanian regions.

Habitat. From the tidal zone sublittorally to about $15 \mathrm{~m}$ associated with Zostera or on weeds with the same habit, extending into brackish water.

Subfossil finds. The Bælt Sea, Baltic, Kattegat, Limfjord, North Sea and Vendsyssel areas, Holocene. During the Eemian in the Bælt Sea and North Sea regions.

\section{Rissoa parva (da Costa 1779)}

Distribution. From Norway, north of Lofoten and the Faeroes, south to the Mediterranean, found in the Limfjord (Petersen 1986a) and the northern part of the Øresund but not in the Baltic according to Fretter \& Graham (1978b). However, Bondesen (1975) includes the species in the Baltic, but excludes it from the Brelt Sea. Petersen (1888, p. 93) regarded the species as being limited to the central part of the Kattegat, depending on sufficient salt content - therefore the information of the occurrences in the Baltic given by Bondesen (1975) is surprising.

Occurrence. The Boreal and Lusitanian regions.

Habitat. From the tidal zone to about $25 \mathrm{~m}$ on fronds, smaller weeds and under stones. In the Faeroes from the rock pools and the beach to a depth of $20 \mathrm{~m}$ (Spärck \& Thorson 1931).

Subfossil finds. The Limfjord and Vendsyssel areas, Holocene. During the Eemian recorded from the Bæelt Sea, North Sea and Vendsyssel regions.

\section{Rissoa violacea Desmarest 1814}

Fig. 12

Distribution. Rissoa violacea is not at all recorded from Iceland (Thorson 1941) and the Faroes (Spärck \& Thorson 1931) but from Norway off the Lofoten islands and south. Both of the recent subspecies are recorded from the Kattegat, including the Øresund region. Bon- 
desen (1975) has Rissoa violacea sensu lato from the Skagerrak, the Kattegat and the Limfjord regions.

Occurrence. The Boreal and Lusitanian regions.

Habitat. In the tidal zone to about $50 \mathrm{~m}$ on weeds and amongst sandy gravel.

Subfossil finds. The Limfjord, North Sea, Vendsyssel and Skagen areas, Holocene. In Skagen recorded from the Subatlantic. The species occurred during the Eemian in the Kattegat region.

\section{Assiminea grayana Fleming 1828}

Distribution. The species is confined to the North Sea coasts. In Danish waters it extends south to Blåvands Huk.

Occurrence. The Boreal region.

Habitat. The species is limited to the upper parts of the salt-marsh areas on the vegetation.

Subfossil finds. None.

\section{Caecum glabrum (Montagu 1803)}

Distribution. From Norway off Lofoten south to the Mediterranean. It extends into Kattegat, where it has been reported from the northern part (Jensen \& Knudsen 1995), but not from the Limfjord (Petersen 1986a)

Occurrence. The Boreal and Lusitanian regions.

Habitat. Sublittorally to about $250 \mathrm{~m}$ on sandy and sandy-muddy bottoms.

Subfossil finds. The Limfjord, North Sea and Vendsyssel regions, Holocene. Recorded from the Bælt Sea and the North Sea during the Eemian.

\section{Tornus exquisitus (Jeffreys 1883)}

Distribution. Within the Danish waters recorded from northern Kattegat (Jensen \& Knudsen 1995), but no record is given by Fretter \& Graham (1978b, p. 232) so the species is not treated further.

Habitat. Unknown for this species.

Subfossil finds. None.
Fig. 13. Bittium reticulatum (da Costa 1778). GEUS collection. Vejlager XIV, Denmark. $\times$ 9.6. MGUH 25323.

\section{Bittium reticulatum (da Costa 1778)}

Fig. 13

Distribution. From off Lofoten in Norway south to the Mediterranean. It is found through the Skagerrak, Limfjord, Kattegat, including the Øresund, and into the Bæelt Sea, but not from the southern coastal part of the North Sea.

Occurrence. The Boreal and Lusitanian regions.

Habitat. Common in shallow sublittoral water, but recorded to $250 \mathrm{~m}$. Found on soft bottoms in association with weeds.

Subfossil finds. The species is recorded from all regions during the Holocene. From Skagen recorded from the Subatlantic. From the Eemian found in the Bælt Sea, Kattegat, North Sea, and Vendsyssel regions.

\section{Turritella communis Risso 1826}

Fig. 14

Distribution. From the Lofoten Islands south to the Mediterranean. The species extends into all the Danish waters as far as the Øresund.

Occurrence. The Boreal and Lusitanian regions.

Habitat. From 10 to $200 \mathrm{~m}$ depths on soft bottoms.

Subfossil finds. The Limfjord, North Sea, Vendsyssel and Skagen areas, Holocene. In the Skagen area re- 


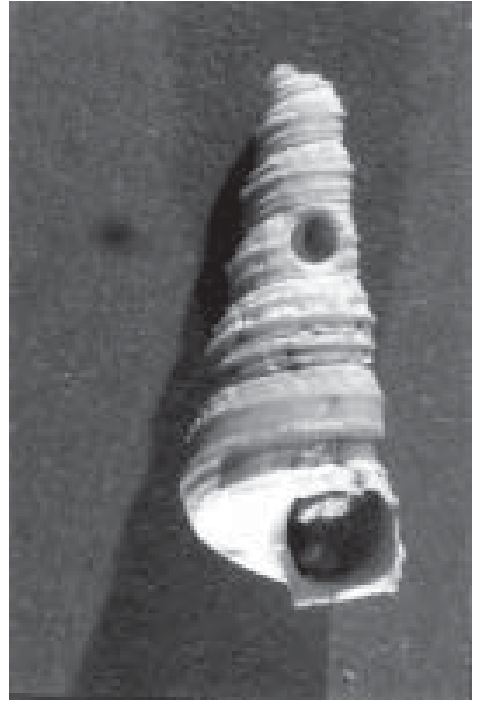

Fig. 14. Turritella communis Risso 1826 Skagen 3, 73.10-73.30 m b.s., lab. no. 722,93 . $\times$ 4.8. MGUH 25324.
Fig. 15. Aporrbais pespelicani (Linnaeus 1758). Skagen 3, 0.0-30.0 $\mathrm{m}$ b.s. (washed sample). $\times$ 4.8. MGUH 25325.

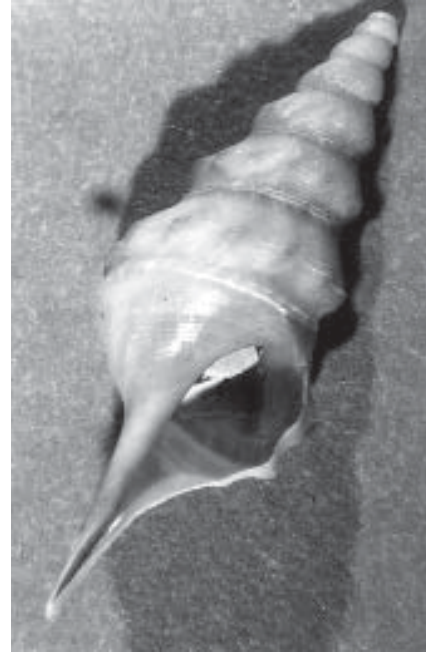

corded from the Subboreal and Subatlantic. During the Eemian recorded from the Baltic, Kattegat, North Sea and Vendsyssel regions.

\section{Turritella erosa Couthouy 1838}

Distribution. West and East Greenland (Thorson 1944b, p. 40), Svalbard and on the northern coast of Russia (Macpherson 1971).

Occurrence. The Arctic and subarctic regions.

Habitat. From 10 to $350 \mathrm{~m}$ on soft bottoms.

Subfossil finds. Recorded from the Vendsyssel region in Early/Middle Weichselian.

\section{Aporrbais pespelicani (Linnaeus 1758)}

Fig. 15

Distribution. On the southern and western part of Iceland, Norway off Lofoten with a questionable occurrence north of Lofoten (Thorson 1941), and south to the Mediterranean. It does not occur off the west coast of Denmark nor in its fjords, except the Limfjord. It extends through the Kattegat, including Øresund (Fretter \& Graham 1981, p. 297). Empty shells are found in Kieler Bucht (Arntz et al. 1976).

Occurrence. The Boreal and Lusitanian regions.

Habitat. Sublittoral to depths of $180 \mathrm{~m}$ on mud, muddy sand and sand.
Subfossil finds. The Baltic, Limfjord, North Sea, Vendsyssel and Skagen areas, Holocene. In the Skagen region from the Subatlantic. During the Eemian recorded from the Bælt Sea, Baltic, North Sea, and Vendsyssel regions.

\section{Aporrbais serresianus (Michaud 1828)}

Distribution. From southern and western Iceland, Norway off Lofoten and south to the Mediterranean. According to Fretter \& Graham (1981) absent from the Skagerrak and all Danish seas; however, Jensen \& Knudsen (1995) note a single record from the central Kattegat.

Occurrence. The Boreal and Lusitanian regions.

Habitat. From Sublittoral (as Aporrhais pespelicani) down to $1000 \mathrm{~m}$ on finer muds.

Subfossil finds. None.

\section{Crepidula fornicata (Linnaeus 1758)}

Distribution. C. fornicata is a late immigrant to Europe (first recorded in the British Isles late in the 19th century). The present distribution is from Norway south to Portugal. It reached the Limfjord in 1934. In 194950 it was found in the northern part of Kattegat but has not spread further south (Jensen \& Knudsen 1995). 
Occurrence. The Boreal-Lusitanian regions within its European distribution. Crepidula fornicata was transferred by man as seen also for species like Mya arenaria.

Habitat. Sublittoral to depths of $c .10 \mathrm{~m}$. The animals live in chains, the oldest attached to a substrate which might be an oyster. The species was actually transported to Europe with oysters (Fretter \& Graham 1981, p. 311).

Subfossil finds. Obviously none.

\section{Capulus ungaricus (Linnaeus 1758)}

Distribution. Empty shells recorded from SW and NW Iceland and living specimens from Norway north of Lofoten south to the Mediterranean. The record from Greenland mentioned in Fretter \& Graham (1981) cannot be sustained in the literature (Thorson 1944b, 1951).

Occurrence. The Boreal and Lusitanian regions.

Habitat. Usually sublittorally to $805 \mathrm{~m}$ attached to stones or the host animal.

Subfossil finds. None (young date from the North Sea).

\section{Lamellaria perspicua (Linnaeus 1758)}

Distribution. SW and NW Iceland, Norway from Lofoten and south to the Mediterranean. It occurs in the Skagerrak but not on the Danish coasts.

Occurrence. The Boreal and Lusitanian regions.

Habitat. From the tidal zone and downwards to depths of $1200 \mathrm{~m}$, especially in the southern parts of its range on rocky shores and under stones.

Subfossil finds. None.

\section{Velutina plicatilis (Müller 1776)}

Distribution. From East Greenland and Spitsbergen, southern and western Iceland, Norway north of Lofoten and south to northern Spain. It extends into the Skagerrak, Kattegat and the northern part of the North Sea.
Occurrence. The Arctic, Subarctic, Boreal and Lusitanian regions.

Habitat. From 10 to c. 375 m deep on hard bottoms, usually in association with ascidians and hydroids.

Subfossil finds. None.

\section{Velutina velutina (Müller 1776)}

Distribution. From Spitsbergen, E and W Greenland, around Iceland and Norway south to the Mediterranean. It extends into the Skagerrak and Kattegat, including Øresund.

Occurrence. Arctic, Subarctic, Boreal and Lusitanian regions.

Habitat. Sublittoral extending to $1000 \mathrm{~m}$ on hard bottoms associated with tunicates.

Subfossil finds. None.

\section{Trivia arctica (Pulteney 1799)}

Distribution. From Norway off Lofoten and south to the Mediterranean. It extends into the Skagerrak and Kattegat (Jensen \& Knudsen 1995).

Occurrence. The Boreal and Lusitanian regions.

Habitat. Sublittoral to about $100 \mathrm{~m}$, in southerly latitudes to about $1000 \mathrm{~m}$. It is associated with ascidians.

Subfossil finds. None.

\section{Trivia monacha (da Costa 1778)}

Distribution. From the British Isles south to the Mediterranean. The recent distribution in the North Sea is questioned, and the species is not recorded from Scandinavia (Fretter \& Graham 1981, p. 329).

Occurrence. The Lusitanian region.

Habitat. On rocky shores and under stones associated with ascidians.

Subfossil finds. The Vendsyssel region, Holocene. 


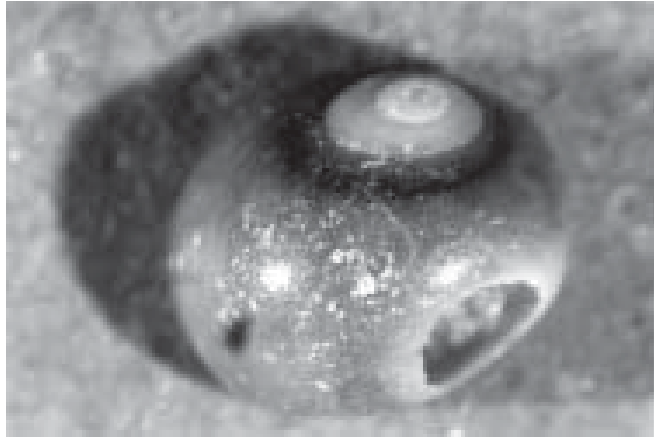

Fig. 16. Lunatia alderi (Forbes 1838). Skagen 4, 26.0-26.5 m b.s., lab. no. 351,93. × 20. MGUH 25326.

\section{Amauropsis islandicus (Gmelin 1791)}

Distribution. From Spitsbergen, E and W Greenland, around Iceland and Norway. It extends into the Skagerrak and Kattegat, including Øresund, although it is rare there (Jensen \& Knudsen 1995).

Occurrence. The Arctic, Subarctic and Boreal regions.

Habitat. Sublittorally to about $80 \mathrm{~m}$ deep on sandy clay bottoms.

Subfossil finds. None (late date from the North Sea).

\section{Lunatia alderi (Forbes 1838)}

Fig. 16

Distribution. From southern and western Iceland and Norway off the Lofoten islands south to the Mediterranean (Thorson 1941). It extends into the Skagerrak, Kattegat and Øresund, but the species is not recorded from the Limfjord (Petersen 1986a).

Occurrence. The Boreal and Lusitanian regions.

Habitat. Sublittoral between 10 and $50 \mathrm{~m}$, extending to $2000 \mathrm{~m}$. Infaunal on sandy shores, clean sand and some admixture of mud. According to Petersen (1888), it is common on mixed bottoms in the Kattegat.

Subfossil finds. The Limfjord, North Sea, Vendsyssel and Skagen regions, Holocene. From the Skagen area recorded from the Atlantic, Subboreal and Subatlantic. From the Eemian recorded from the Baltic, Kattegat, North Sea, Vendsyssel and Skagen regions.

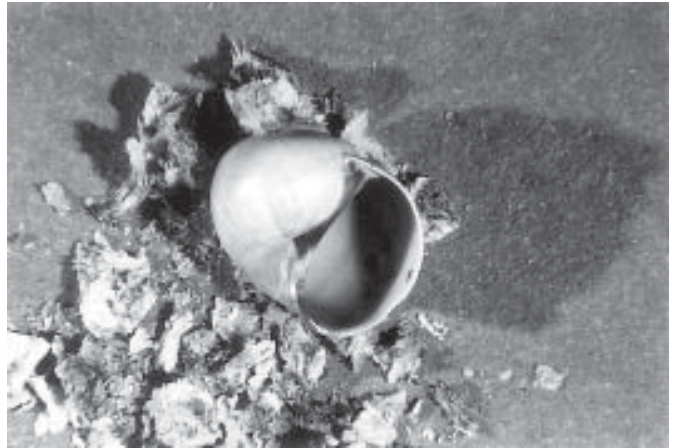

Fig. 17. Lunatia montagui (Forbes 1838). Skagen 4, 20.0-20.5 m b.s., lab. no. 345,93. × 4.8. MGUH 25327.

\section{Lunatia catena (da Costa 1778)}

Distribution. From the Skagerrak and Kattegat, including Øresund but not the Limfjord, south to the Mediterranean (Fretter \& Graham 1981, p. 339).

Occurrence. The Boreal and Lusitanian regions.

Habitat. From the tidal zone down to about $125 \mathrm{~m}$ on sandy bottoms.

Subfossil finds. The Limfjord, North Sea and Vendsyssel regions, Holocene.

\section{Lunatia montagui (Forbes 1838)}

Fig. 17

Distribution. From W and S Iceland, Norway north of the Lofoten islands, and south to the Mediterranean. It occurs in the Skagerrak and Kattegat, including Øresund, however, rare in the Sound as the presiding species according to Jensen \& Knudsen (1995).

Occurrence. The Boreal and Lusitanian regions.

Habitat. From 15 to 200 m depth on sandy and muddy bottoms.

Subfossil finds. Recorded from the Skagen Well from the Subatlantic. 


\section{Lunatia pallida (Broderip \& Sowerby 1829)}

Distribution. From Spitsbergen, E and W Greenland, around Iceland and Norway, south to the North Sea, Skagerrak and the Kattegat, including the Øresund.

Occurrence. The Arctic, Subarctic and Boreal regions.

Habitat. From 10 to $2000 \mathrm{~m}$ on clay bottoms - the greatest depths in the most southerly parts of its range (Fretter \& Graham 1981). In Greenland waters common in the Arctic Macoma community (Thorson 1944b).

Subfossil finds. The Vendsyssel region during the Early/ Middle Weichselian and Late Weichselian (the Older and Younger Yoldia Sea respectively).

\section{Natica affinis (Gmelin 1790)}

Distribution. From Spitsbergen, W and E Greenland, around Iceland and Norway south to the Mediterranean. However, within the Lusitanian region the species lives in deep water (Fretter \& Graham 1981, p. 345). The species is recorded from Danish waters (Jensen \& Knudsen 1995).

Occurrence. The Arctic, Subarctic, Boreal and Lusitanian regions.

Habitat. From about $4 \mathrm{~m}$ depth in high latitudes to well over $2000 \mathrm{~m}$ in low ones on sandy, muddy and clay bottoms. As mentioned for other species with a wide geographical distribution this is a 'tropical submerge' which is quite common for cold-water animals which in the northern regions inhabit the surface water to occur mainly or exclusively in deeper zones in the southern seas (Ekman 1953, p. 112).

The species is found in the Arctic Macoma community (Spärck 1937).

Subfossil finds. Recorded from the Vendsyssel area during the Early/Middle Weichselian (the Older Yoldia Sea), and the Late Weichselian (the Younger Yoldia Sea).

\section{Order Heterogastropoda}

\section{Triphora adversa (Montagu 1803)}

Distribution. From Norway off the Lofoten islands and south to Spain. It extends into the Kattegat, including Øresund and the Brelt Sea, but not recorded from the Limfjord.

Occurrence. The Boreal and Lusitanian regions.

Habitat. Sublittorally to $100 \mathrm{~m}$ under stones, algae or associated with sponges.

Subfossil finds. The Bælt Sea, Kattegat, Limfjord, North Sea and Vendsyssel areas, Holocene. Recorded from the Bælt Sea and the North Sea during the Eemian.

\section{Ceritbiella metula (Lovén 1846)}

Distribution. S and W Iceland, Norway north of Lofoten, and south to the Mediterranean. Recorded from the Danish waters (Jensen \& Knudsen 1995), although rare in the Skagerrak and not occurring in the Kattegat (Fretter \& Graham 1982, p. 377).

Occurrence. The Boreal and Lusitanian regions.

Habitat. From 40 to $400 \mathrm{~m}$ depth on soft bottoms.

Subfossil finds. None.

\section{Cerithiopsis barleei Jeffreys 1867}

Distribution. According to Fretter \& Graham (1982), from SW England south to the Mediterranean. However, the species is recorded from Danish waters, i.e. the Øresund area, although as rare (Jensen \& Knudsen 1995), but is not found in the Limfjord (Petersen 1986a).

Occurrence. The Boreal and Lusitanian regions.

Habitat. Sublittorally associated with sponges.

Subfossil finds. The Limfjord region, Holocene. 


\section{Ceritbiopsis tubercularis (Montagu 1803)}

Distribution. From Norway off the Lofoten islands and south to the Mediterranean. Recorded from the Swedish west coast, but not in Danish waters (Fretter \& Graham 1982).

Occurrence. The Boreal and Lusitanian regions.

Habitat. From the tidal zone and sublittorally to $100 \mathrm{~m}$. The species is found on sponges.

Only subfossil finds. The Limfjord region, Holocene, and the North Sea during the Eemian.

\section{Epitonium clatbratulum (Kanmacher 1797)}

Distribution. From Norway and south to the Mediterranean. It extends into the Kattegat, including the Øresund.

Occurrence. The Boreal and Lusitanian regions.

Habitat. From 30 to $100 \mathrm{~m}$ deep on sandy-muddy bottoms.

Subfossil finds. None.

\section{Epitonium clatbrus (Linnaeus 1758)}

Distribution. From Norway off the Lofoten islands and south to the Mediterranean. The species extends into the Kattegat and Øresund (Jensen \& Knudsen 1995), but does not enter the Danish fjords (Fretter \& Graham 1982, p. 387).

Occurrence. The Boreal and Lusitanian regions.

Habitat. Sublittorally from 5 to 70 m on sandy-muddy bottoms.

Subfossil finds. The Limfjord, North Sea and Vendsyssel regions, Holocene. Recorded from the Bælt Sea and the North Sea during the Eemian.

\section{Epitonium trevelyanum (Johnston 1841)}

Fig. 18

Distribution. From Norway off the Lofoten islands and south to the Mediterranean. The species extends into the Kattegat, including the Øresund.
Fig. 18. Epitonium trevelyanum (Johnston 1841). Skagen 3, 58.5$60.0 \mathrm{~m}$ b.s., lab. no. 98,93. × 9.6. MGUH 25328.

Occurrence. The Boreal and Lusitanian regions.

Habitat. From 30 to $200 \mathrm{~m}$ depth on sandy-muddy bottoms.

Subfossil finds. The Skagen area, Holocene, recorded from the Subboreal and the Subatlantic.

\section{Epitonium turtonis (Turton 1819)}

Distribution. From Norway off the Lofoten islands (Thorson 1941) and south to the Mediterranean. Occurring in the Kattegat (Fretter \& Graham 1982) and Øresund (Jensen \& Knudsen 1995).

Occurrence. The Boreal and Lusitanian regions.

Habitat. From 5 to $20 \mathrm{~m}$ deep on sandy-muddy bottoms.

Subfossil finds. The Limfjord and Vendsyssel regions, Holocene.

\section{Aclis ascaris (Turton 1819)}

Distribution. From Norway off Lofoten and south to the Mediterranean. The species extends into the Skagerrak and Kattegat, including the Øresund.

Occurrence. The Boreal and Lusitanian regions.

Habitat. From 10 to $50 \mathrm{~m}$ deep on soft sandy bottoms.

Subfossil finds. The North Sea, Holocene. 


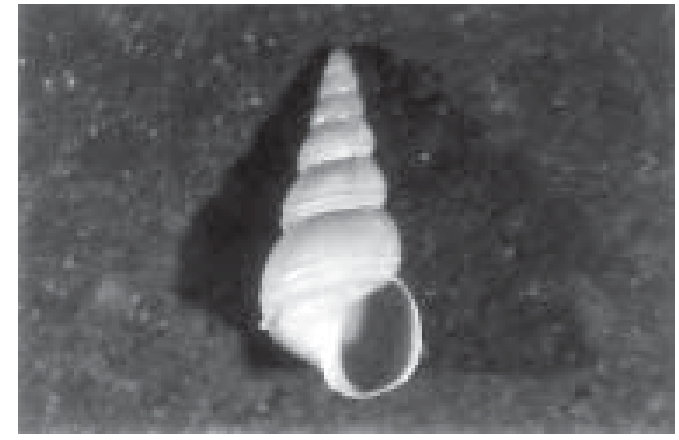

Fig. 19. Aclis minor (Brown 1827). Skagen 3, 55.1-55.3 m b.s., lab. no. 716,93. × 20. MGUH 25329.

\section{Aclis minor (Brown 1827)}

Fig. 19

Distribution. From Norway off the Lofoten islands and south to the Mediterranean. The species is recorded from the southern Kattegat and Øresund.

Occurrence. The Boreal and Lusitanian regions.

Habitat. From 15 to $150 \mathrm{~m}$ deep on bottoms of sand, muddy sand or gravel.

Subfossil finds. The Limfjord, North Sea and Skagen areas, Holocene; in the Skagen Well recorded from the Atlantic, Subboreal and Subatlantic.

\section{Aclis walleri Jeffreys 1867}

Distribution. From Norway off the Lofoten islands and south to the Mediterranean. Recorded from north of Skagen (Petersen 1888) and the Limfjord (Petersen 1986a).

Occurrence. The Boreal and Lusitanian regions.

Habitat. According to Fretter \& Graham (1982), at greater depths than the other Aclis ssp. - down to $550 \mathrm{~m}$ on soft bottoms.

Subfossil finds. The North Sea, Holocene.

\section{Eulima bilineata (Alder 1848)}

Distribution. From Norway north of Lofoten, south to the Mediterranean. In the Danish waters recorded from the southern Kattegat.

Occurrence. The Boreal and Lusitanian regions.
Habitat. From 20 to $250 \mathrm{~m}$ deep on soft bottoms associated with ophiuroids.

Subfossil finds. None.

\section{Haliella stenostoma (Jeffreys 1858)}

Distribution. Off West Greenland, around Iceland, Norway off the Lofoten islands, and south to the Mediterranean.

Occurrence. The Subarctic, Boreal and Lusitanian regions.

Habitat. Sublittoral from about 70 to $3000 \mathrm{~m}$ on soft bottoms. The species has its main occurrence at rather great depths (Thorson 1941), but is also recorded from Danish waters (Jensen \& Knudsen 1995).

Subfossil finds. None.

\section{Polygireulima sinuosa (Sacco 1836)}

Fig. 20

Distribution. From the Kattegat and south to the Mediterranean.

Occurrence. The Boreal and Lusitanian regions.

Habitat. Sublittoral from 30 to $150 \mathrm{~m}$ on soft bottoms.

Subfossil finds. The Skagen area, Holocene, recorded from the Subatlantic.

Fig. 20. Polygireulima sinuosa (Sacco 1836). Skagen 3, 38.19-38.24 m b.s., core sample K-6. $\times$ 9.6. MGUH 25330.

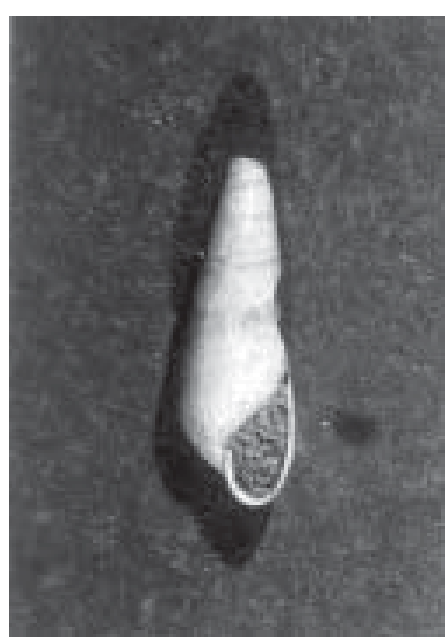




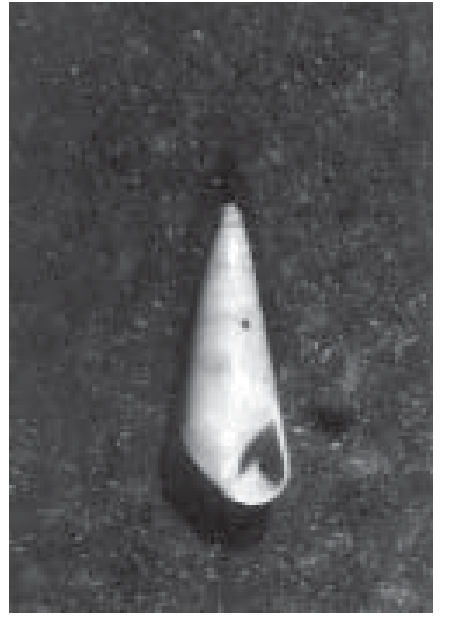

Fig. 21. Vitreolina collensi (Sykes 1903).

Skagen 3, 70.10-70.30 m b.s., lab. no. 721,93. $\times 20$. MGUH 25331

\section{Polygireulima monterosatoi (Monterosato 1890)}

Distribution. Norway south of the Lofoten islands, and south to the Mediterranean.

Occurrence. The Boreal and Lusitanian regions.

Habitat. From 20 to $120 \mathrm{~m}$ deep on sandy muddy or gravelly bottoms. However, as Fretter \& Graham (1982, p. 421) say: "presumably these animals attack echinoderms like their relatives, but which is not known".

Subfossil finds. None.

\section{Vitreolina collensi (Sykes 1903)}

Fig. 21

Distribution. From the west coast of Britain and Ireland to the Mediterranean.
Occurrence. The Lusitanian region.

Habitat. Sublittorally to 35-40 m on soft bottoms.

Only subfossil finds. The Skagen area, Holocene, recorded from the Subboreal and the Subatlantic.

\section{Vitreolina philippii (Reyneval \& Ponzi 1854)}

Fig. 22a, b

Distribution. From Norway off the Lofoten islands and south to the Mediterranean. According to Petersen (1888), very common in Danish waters from the Skagerrak, the Kattegat and the Øresund, and the Brelt Sea, but not recorded from the Limfjord (Petersen 1986a)

Occurrence. The Boreal and Lusitanian regions.

Habitat. From the lowest part of the tidal zone to a depth of $200 \mathrm{~m}$ on soft bottoms. Fretter \& Graham (1982, p. 422) hold it as perhaps the most common local eulimid and like other eulimids an intermittent parasite of echinoderms.

Subfossil finds. The Limfjord, Vendsyssel and Skagen areas, Holocene, recorded from the Subatlantic in the Skagen Well. Occurring in the Eemian in the Vendsyssel region.

\section{Grapbis albida (Kanmacher 1798)}

Fig. 23

Distribution. From southern Norway south to the Mediterranean. The species has a record from the Limfjord (Petersen 1986a).

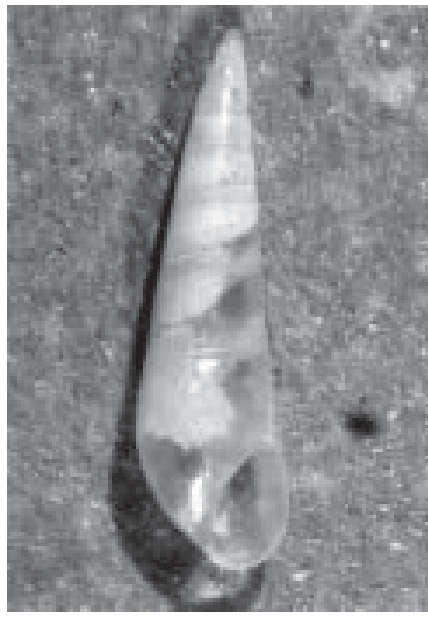

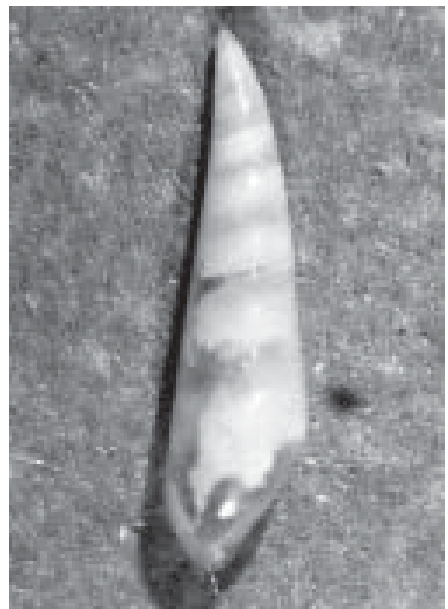

Fig. 22. a, b: Vitreolina philippii (Rayneval \& Pouzi 1854). Skagen 4, 21.0-21.5 m b.s., lab. no. 346,93. $\times 20$. MGUH 25332. 


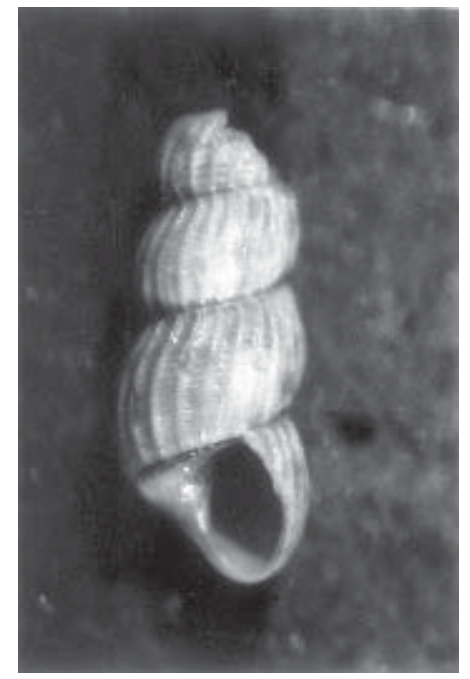

Fig. 23. Graphis albida (Kanmacher 1798). Skagen 4, 25.0-25.5 m b.s., lab. no. 350,93 . $\times$ 40. MGUH 25333.
Fig. 25. Melanella alba (da Costa 1778). Skagen 3, 74.89-75.00 m b.s. lab. no. $509,93 . \times 40$ MGUH 25335.

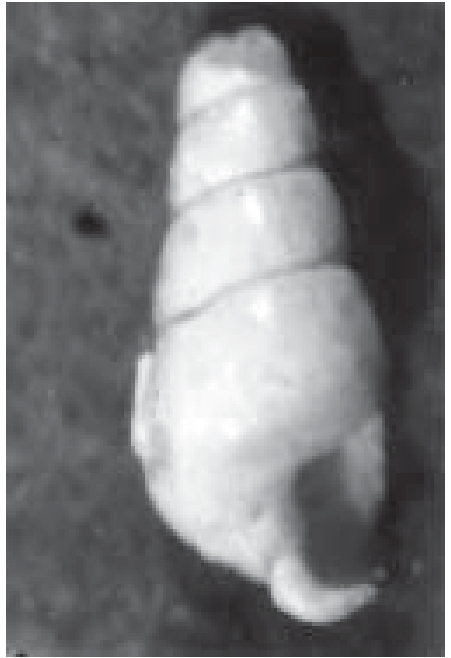

Occurrence. The Boreal and Lusitanian regions.

Habitat. From low in the tidal zone to $30 \mathrm{~m}$ deep on muddy and sandy bottoms.

Only subfossil finds. The Skagen Well area, Holocene, recorded from the Subatlantic.

\section{Melanella lubrica (Monterosato 1891)}

Fig. 24

Distribution. From Norway south to Iberia. The species is recorded from the Danish waters south into the Øresund (Jensen \& Knudsen 1995).

Occurrence. The Boreal and Lusitanian regions.

Habitat. From 14 to $100 \mathrm{~m}$ on soft bottoms of muddy

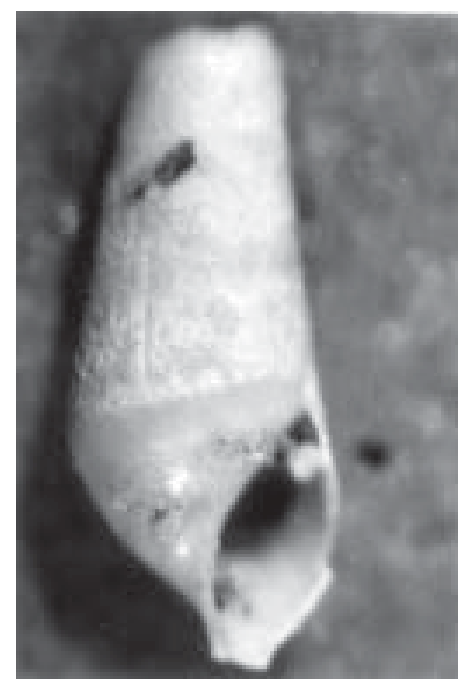

Fig. 24. Melanella lubrica (Monterosato 1891). Skagen 3, 83.73$83.83 \mathrm{~m}$ b.s., lab. no. 512,93. × 40. MGUH 25334 . sand and gravel. The species is an intermittent ectoparasite (Fretter \& Graham 1982).

Subfossil finds. The Skagen area, Holocene, recorded from the Atlantic and Subatlantic.

\section{Melanella alba (da Costa 1778)}

Fig. 25

Distribution. From Norway off the Lofoten islands and south to the Mediterranean.

Occurrence. The Boreal and Lusitanian regions.

Habitat. From 16 to $135 \mathrm{~m}$ deep on muddy sand and gravel bottoms, an ectoparasite of holothurians.

Only subfossil finds. The Skagen Well area, Holocene, recorded from the Subboreal.

\section{Hemiaclis ventrosa (Jeffreys MS Fricle 1874)}

Fig. 26

Distribution. From west and south Iceland, Norway off the Lofoten islands, and south to the Bay of Biscay.

Occurrence. The Boreal and Lusitanian regions.

Habitat. From 100 to 300 m deep on soft bottoms.

Only subfossil finds. The Skagen Well area, Holocene, recorded from the Subatlantic. 


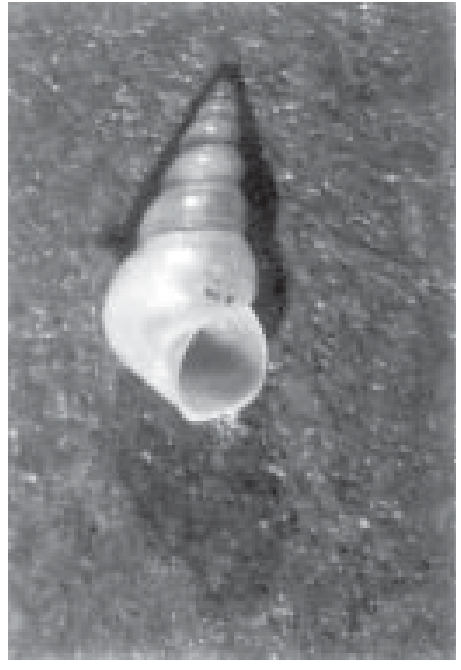

Fig. 26. Hemiaclis ventrosa (Jeffreys MS Fricle 1874). Skagen 4, 30.0-30.5 m b.s., lab. no. $355,93 . \times 20$. MGUH 25336

\section{Pelseneeria stylifera (Turton 1826)}

Distribution. From Norway off the Lofoten islands and south to the Mediterranean. Few recorded from the Skagerrak and Kattegat, including Øresund (Jensen \& Knudsen 1995).

Occurrence. The Boreal and Lusitanian regions.

Habitat. The animals are confined to the surface of regular sea urchins (Fretter \& Graham 1982, p. 431).

Subfossil finds. None.

\section{Enteroxenos oestergreni Bonnevie 1902}

Distribution. Recorded from Scandinavia, a single Danish record (Jensen \& Knudsen 1995).

Occurrence. The Boreal region.

Habitat. A parasite in the holothurian Stichopus tremulus (Jensen \& Knudsen 1995).

Subfossil finds. None.

\section{Order Neogastropoda}

\section{Nucella lapillus (Linnaeus 1758)}

Distribution. W Greenland, around Iceland, Norway from north of Lofoten, and south to the Straits of Gibraltar. The species reaches into the Skagerrak, but it is uncommon in Danish waters (Fretter \& Graham 1984). However, it occurs on breakwaters along the North Sea and Skagerrak coasts. There are a few records from the southern Kattegat and Øresund (Jensen \& Knudsen 1995).

Occurrence. The Subarctic, Boreal and Lusitanian regions.

Habitat. Intertidal on rocky shores and extends, albeit rarely, to depths of 30 to $40 \mathrm{~m}$. It avoids very weedy shores and seems to stand only limited reduction of salinity (Fretter \& Graham 1984, p. 445).

Subfossilfinds. The Kattegat, Limfjord (exposed towards the Skagerrak), North Sea and Vendsyssel regions, Holocene.

\section{Boreotropbon clatbratus (Linnaeus 1767)}

Distribution. Spitsbergen, E and W Greenland, around Iceland, the Faroes and the coast of Norway south to the Skagerrak and Kattegat.

Occurrence. The Arctic, Subarctic and Boreal regions.

Habitat. From $8 \mathrm{~m}$ to over $1000 \mathrm{~m}$ on soft bottoms.

Subfossil finds. The Vendsyssel area, Late Weichselian (the Younger Yoldia Sea).

\section{Boreotrophon truncatus (Ström 1768)}

Distribution. Spitsbergen, E and W Greenland, around Iceland, Norway south to the Biscay. The species extends in to Danish waters south to the Øresund.

Occurrence. The Arctic, Subarctic, Boreal and Lusitanian regions.

Habitat. From the laminarian zone to depths of about $200 \mathrm{~m}$ on bottoms of a stony, gravelly or muddy nature.

Subfossil finds. None.

\section{Ocenebra erinacea (Linnaeus 1758)}

Distribution. From the southern coasts of Britain south to the Mediterranean. However, the few records from 
Danish waters might have been introduced with oysters (Jensen \& Knudsen 1995).

Occurrence. The Lusitanian region.

Habitat. Sublittoral to $150 \mathrm{~m}$ deep on stony bottoms.

Subfossil finds. None.

\section{Tropbonopsis barvicensis (Johnston 1825)}

Distribution. W and S Iceland, Norway and south to the British Isles, and further south (France) at greater depths. In Danish waters from the Kattegat, including the Øresund, although rare (Jensen \& Knudsen 1995).

Occurrence. The Boreal and Lusitanian regions.

Habitat. Sublittoral at a few metres' depth at the northern end of its range to 300-400 $\mathrm{m}$ at the southern end.

Subfossil finds. None.

\section{Buccinum undatum Linnaeus 1758}

Fig. 27

Distribution. Spitsbergen, W Greenland, around Iceland, Norway and south to the Bay of Biscay (Thorson 1944b). The species extends into the Kattegat, Limfjord, and the Bælt Sea with the Mecklenburger Bucht as the easternmost position.

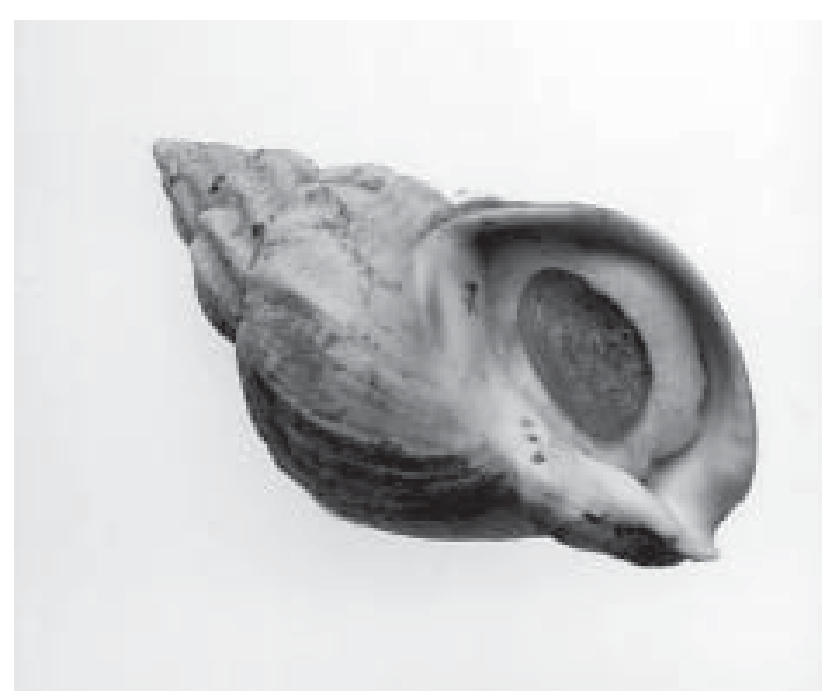

Fig. 27. Buccinum undatum Linnaeus 1758. GEUS collection. Limfjord, Denmark. Height 70 mm. MGUH 25337.
Occurrence. The Subarctic, Boreal and Lusitanian regions.

Habitat. Sublittorally to about 1200 m deep usually on soft bottoms.

Subfossil finds. The Kattegat, Limfjord, North Sea, Vendsyssel and Skagen areas, Holocene, recorded as a fragment from the Skagen Well from the Subatlantic. During the Eemian in the Kattegat, North Sea, and Vendsyssel regions. From the Vendsyssel area found during the Late Weichselian (the Younger Yoldia Sea).

\section{Buccinum cyaneum Bruguière 1792}

Distribution. Spitsbergen, W and E Greenland around Iceland and Norway north of Lofoten.

Occurrence. The Arctic, Subarctic and northern part of the Boreal regions.

Habitat. From 0 to 392 m on all sorts of bottoms - sand, clay, stones and algae (Thorson 1944b).

Only subfossil finds. From the Vendsyssel area recorded during the Late Weichselian (the Younger Yoldia Sea).

\section{Colus gracilis (da Costa 1778)}

Distribution. S and W Iceland (empty shells), Norway off the Lofoten islands and south to Portugal. The species extends into the Kattegat.

Occurrence. The Boreal and Lusitanian regions.

Habitat. Usually from 30 to $800 \mathrm{~m}$ deep (less common and deeper in the south).

Subfossil finds. None.

\section{Colus jeffreysianus (Fischer 1868)}

Distribution. From Norway south to the Mediterranean. The species extends through the Skagerrak to the Kattegat, including the northern part of the Øresund.

Occurrence. The Boreal and Lusitanian regions.

Habitat. From 30 to 2000 m deep on soft bottoms.

Subfossil finds. None. 


\section{Colus sabini (Gray 1824)}

Distribution. From W Greenland (empty shells) and S and W Iceland, northern North Sea and extending into the Skagerrak (Jensen \& Knudsen 1995).

Occurrence. The Boreal region. (A Subarctic extension is not considered, since only empty shells have been found off W Greenland and no occurrences on $\mathrm{N}$ and E Iceland (Thorson 1941, 1944b).)

Habitat. From 35 to 1500 m deep on muddy bottoms. Subfossil finds. None.

\section{Liomesus ovum (Turton 1825)}

Distribution. From Greenland, the Faeroes and the coasts of Norway. According to Fretter \& Graham (1984, p. 465), the species is not recorded from the Skagerrak or Kattegat; however, Jensen \& Knudsen (1995) mentioned this species as occurring in Danish waters. Furthermore, the species Liomesus ovum cannot be found in Thorson (1944b), who has Buccinum ovum Middendorff, which is not the same according to Fretter \& Graham (1962), and the occurrence off the Faeroes cannot be confirmed in Spärck \& Thorson (1931).

Occurrence. The Boreal region with only uncertain outposts into the Subarctic and Lusitanian regions.

Habitat. From 70 to $400 \mathrm{~m}$ deep on soft bottoms.

Subfossil finds. None.

\section{Neptunea antiqua (Linnaeus 1758)}

Distribution. From southern Norway south to the Bay of Biscay. The species extends into the Kattegat, Øresund (Jensen \& Knudsen 1995), and the Bælt Sea as far east as Lübecker Bucht. The species has also been recorded from the Limfjord (Petersen 1986a).

Occurrence. The Boreal and Lusitanian regions.

Habitat. From 15 to $1200 \mathrm{~m}$ on all kinds of bottom, mainly soft.

Subfossil finds. The Vendsyssel area, Holocene.
Neptunea despecta (Linnaeus 1758)

Distribution. From Spitsbergen, E and W Greenland, around Iceland and the coasts of Norway, south to the seas off Denmark according to Fretter \& Graham (1984), but not mentioned by Jensen \& Knudsen (1995) in their annotated check list of recent marine molluscs of Danish waters.

Occurrence. The Arctic, Subarctic and Boreal regions.

Habitat. From 6 to 1400 m on soft bottoms.

Only subfossil finds. The Vendsyssel region during the Late Weichselian (the Younger Yoldia Sea).

\section{Turrisipho moebii (Dunker \& Metzger 1874)}

Distribution. From the coasts of northern and southern Norway and the Faeroes (Sipho sarsi in Spärck \& Thorson 1931). The species extends into the Skagerrak.

Occurrence. The Boreal region.

Habitat. From 200 m to 1000 m deep on soft bottoms. Subfossil finds. None.

\section{Hinia incrassata (Ström 1768)}

Distribution. S and W Iceland, Norway north of Lofoten, and south to the Mediterranean (Thorson 1941). The species extends into the Kattegat and Øresund, although rare in this place (Jensen \& Knudsen 1995), and it has not been found in the Limfjord (Petersen 1986a).

Occurrence. The Boreal and Lusitanian regions.

Habitat. Rocky coasts in the lower part of the tidal zone. Mainly found in the shallow sublittoral, but may extend to about $200 \mathrm{~m}$.

Subfossil finds. The Limfjord and Vendsyssel regions, Holocene. Recorded from the Vendsyssel region during the Eemian.

\section{Hinia pygmaea (Lamarck 1822)}

Fig. 28

Distribution. From Norway off the Lofoten islands and 


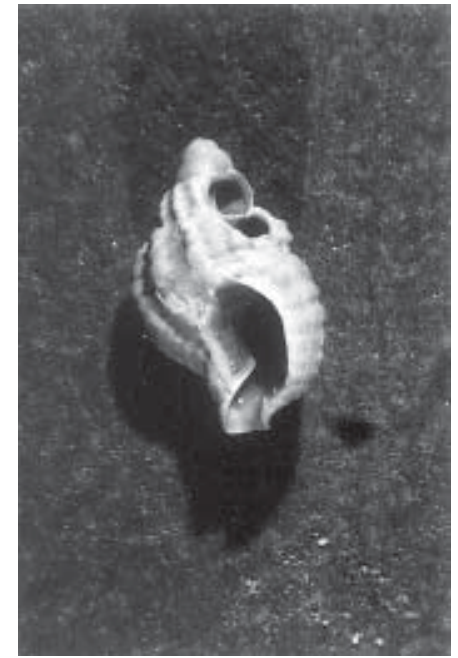

Fig. 28. Hinia pygmaea (Lamarck 1822). Skagen 4, 12.0-12.5 m b.s., lab. no. $337,93 . \times$ 9.6. MGUH 25338.
Fig. 29. Hinia reticulata (Linnaeus 1758)

Skagen 3, 55.10-55.30

m b.s., lab. no. 716,93.

$\times$ 4.8. MGUH 25339.

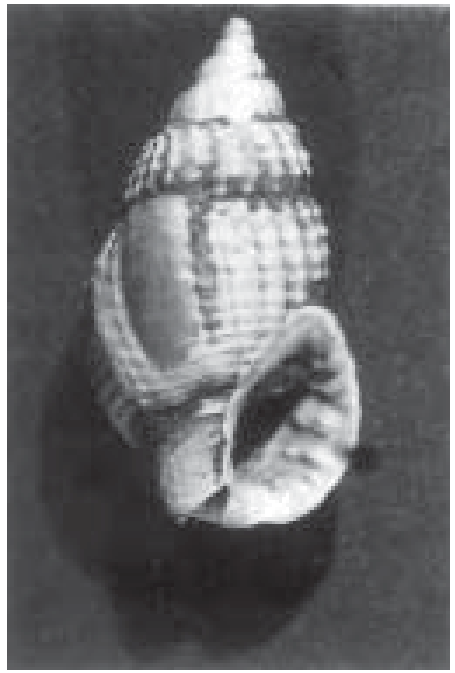

south to the Mediterranean. It extends into Danish waters such as the Skagerrak, Limfjord and Kattegat and Øresund.

Occurrence. The Boreal and Lusitanian regions.

Habitat. From $1 \mathrm{~m}$ to about $200 \mathrm{~m}$ on sandy bottoms.

Subfossil finds. The Limfjord, North Sea, Vendsyssel and Skagen areas, Holocene. Recorded from the Subatlantic in the Skagen Well material. Found in the Bælt Sea, Kattegat and North Sea regions during the Eemian.

\section{Hinia reticulata (Linnaeus 1758)}

Fig. 29

Distribution. From Norway off Lofoten and south to the Mediterranean. In Danish waters within the Limfjord and Kattegat with fjords, the Øresund and the Bælt Sea.

Occurrence. The Boreal and Lusitanian regions.

Habitat. From the tidal zone to about $15 \mathrm{~m}$ deep on soft bottoms.

Subfossil finds. The Bælt Sea, Baltic, Kattegat, Limfjord, North Sea, Vendsyssel and Skagen regions, Holocene. In the Skagen Well material recorded from the Subatlantic. From the Bælt Sea, Baltic, Kattegat, North Sea and Vendsyssel regions recorded from the Eemian.

\section{Troschelia bernicensis (King 1846)}

Distribution. From Norway north of Lofoten and south to the west coast of Scotland and the Dogger Bank. Recorded from Danish waters by Jensen \& Knudsen (1995).

Occurrence. The Boreal and Lusitanian (northern part) regions.

Habitat. Lives on the continental shelves and upper slopes, between 90 and 2700 m (Poppe \& Goto 1991).

Subfossil finds. None.

\section{Cytbarella coarctata (Forbes 1840)}

Distribution. From Norway off the Lofoten islands (Thorson 1941: Mangelia costata) and south to the Mediterranean. The species is recorded from the Skagerrak and Kattegat where it extends into the Øresund (Jensen \& Knudsen 1995).

Occurrence. The Boreal and Lusitanian regions.

Habitat. From the tidal zone to $250 \mathrm{~m}$ deep on sandy bottoms.

Subfossil finds. The Vendsyssel area, Holocene. During the Eemian in the North Sea region.

\section{Oenopota incisula (Verrill 1882)}

Distribution. The species is known from the Boreal zone of the east coast of North America, and is com- 
mon off West Greenland (Posselt \& Jensen 1898), but it is not recorded from Iceland or the coasts of the north-east Atlantic (Thorson 1941).

Occurrence. The Arctic, Subarctic, and in North America into the Boreal regions.

Habitat. In the Canadian north-east region the species has been collected from 6-7 to $140 \mathrm{~m}$ deep on clay (Macpherson 1971).

Only subfossil finds. From the Vendsyssel region recorded during the Eemian and Early/Middle Weichselian (the Older Yoldia clay).

\section{Oenopota trevelliana (Turton 1834)}

Distribution. Spitsbergen, E and W Greenland, around Iceland (Thorson 1941: Bela trevelliana (Turton)), Norway from north of Lofoten, and south to the British Isles. The species extends south to the Kattegat, including Øresund.

Occurrence. The Arctic, Subarctic, Boreal and Lusitanian (northern part) regions.

Habitat. Sublittorally from $25 \mathrm{~m}$ to depths over $300 \mathrm{~m}$ on fine sand.

Subfossil finds. The Vendsyssel area during the Eemian.

\section{Oenopota turricola (Montagu 1803)}

Fig. 30

Distribution. Greenland, Iceland, Faeroes, Norway south to Scotland (Spärck \& Thorson 1931). The species extends into the Limfjord and Kattegat (Fretter \& Graham 1984) and the Øresund (Jensen \& Knudsen 1995).

Occurrence. The Arctic, Subarctic and Boreal regions. Habitat. Sublittoral from 20 to $200 \mathrm{~m}$ on sandy bottoms.

Subfossil finds. The Limfjord, Vendsyssel and Skagen areas, Holocene. From the Skagen Well recorded from the Subatlantic. Found in the Vendsyssel area from the Late Weichselian (the Younger Yoldia Sea).
Fig. 30. Oenopota turricola (Montagu 1803). Skagen 4, 21.0$21.5 \mathrm{~m}$ b.s., lab. no. 346,93. × 9.6. MGUH 25340 .

\section{Oenopota violacea (Mighels \& Adams 1842)}

Distribution. E and W Greenland, Spitsbergen, around Iceland and south along the coast of Norway, but not reaching the British Isles (Thorson 1941).

Occurrence. The Arctic, Subarctic and Boreal regions.

Habitat. From $1 \mathrm{~m}$ to $761 \mathrm{~m}$ on mud and stones.

Only subfossil finds. The Vendsyssel area during the Eemian.

\section{Bela exarata G.O. Sars 1878}

Distribution. E and W Greenland, Spitsbergen, around Iceland, the Faeroes, and Norway from north of Lofoten and west of Ireland. The species is also recorded west of Iceland, where it has been found at depths down to $2214 \mathrm{~m}$ (Thorson 1941).

Occurrence. The Arctic, Subarctic, Boreal regions with Lusitanian outposts.

Habitat. In the northern part of its range it belongs to the shallow-water species (Norway and E Greenland from $3 \mathrm{~m}$ ) (Thorson 1941).

Only subfossil finds. From the Eemian in the Vendsyssel area.

\section{Mangelia attenuata (Montagu 1803)}

Distribution. From Norway off the Lofoten islands and 


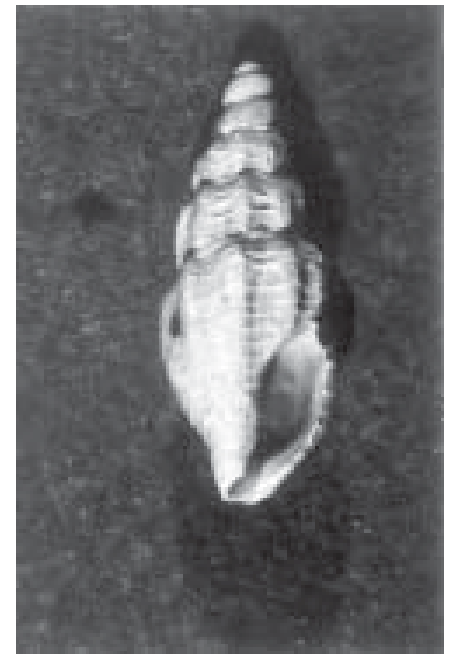

Fig. 31. Mangelia brachystoma (Philippi 1844). Skagen 3, 58.04$58.25 \mathrm{~m}$ b.s., lab. no. 717,93. × 9.6. MGUH 25341 .

south to the Mediterranean. The species extends into the Skagerrak and Kattegat, including the Øresund.

Occurrence. The Boreal and Lusitanian regions.

Habitat. From 5 to $150 \mathrm{~m}$ deep on sand or clay bottoms.

Subfossil finds. None.

\section{Mangelia bracbystoma (Philippi 1844)}

Fig. 31

Distribution. From Norway off the Lofoten islands and south to the Mediterranean. The species extends into the Skagerrak and Kattegat, including the Øresund.

Occurrence. The Boreal and Lusitanian regions.

Habitat. Sublittorally from $4 \mathrm{~m}$ to $60 \mathrm{~m}$ deep on bottoms of sand and sandy mud.

Subfossil finds. The Skagen area, Holocene, recorded from the Subatlantic in the Skagen Well cores. During the Eemian found in the Vendsyssel region.

\section{Mangelia nebula (Montagu 1803)}

Distribution. Norway off the Lofoten islands and south to the Mediterranean. The species is recorded a few times from the Kattegat and extends into the Øresund (Jensen \& Knudsen 1995).

Occurrence. The Boreal and Lusitanian regions.
Habitat. From 10 to $50 \mathrm{~m}$ deep on sandy bottoms.

Subfossil finds. None.

\section{Raphitoma purpurea (Montagu 1803)}

Distribution. From northern Norway off the Lofoten islands south into the Mediterranean.

Occurrence. The Boreal and Lusitanian regions.

Habitat. From 10 to $100 \mathrm{~m}$ deep on sandy, gravelly and stony bottoms.

Only subfossil finds. The Limfjord region, Holocene.

\section{Raphitoma asperrima (Brown 1827)}

Distribution. From the coast of Norway south to the Mediterranean, extending into the Kattegat, including the Øresund (Jensen \& Knudsen 1995).

Occurrence. The Boreal and Lusitanian regions.

Habitat. From 20 to 100 m deep on sandy bottoms.

Subfossil finds. None.

\section{Rapbitoma leufroyi (Michaud 1821)}

Distribution. From the coast of Norway off the Lofoten islands and south to the Mediterranean, extending into the Skagerrak and with a few records from the northern Kattegat (Jensen \& Knudsen 1995).

Occurrence. The Boreal and Lusitanian regions.

Habitat. From the tidal zone to $150 \mathrm{~m}$ deep on sandy, shelly and stony bottoms.

Subfossil finds. None.

\section{Rapbitoma linearis (Montagu 1803)}

Distribution. SW and NW Iceland, Norway from north of Lofoten and south to the Mediterranean. The species extends into the Skagerrak and Kattegat and Øresund, although rare (Jensen \& Knudsen 1995).

Occurrence. The Boreal and Lusitanian regions. 
Habitat. From 10 to $200 \mathrm{~m}$ deep on sandy, shelly and stony bottoms.

Subfossil finds. The Limfjord and Vendsyssel area, Holocene. During the Eemian found in the Vendsyssel area (the Turritella terebra zone in the Skærumhede sequence).

\section{Taranis borealis Bouchet \& Warén 1980}

Distribution. So far as known, this species is confined to waters off western Norway and the Skagerrak (Fretter \& Graham 1984, p. 548).

Occurrence. The Boreal region.

Habitat. From $150 \mathrm{~m}$ to nearly $2000 \mathrm{~m}$ deep on soft bottoms.

Subfossil finds. None.

\section{Taranis moerchi (Malm 1861)}

Distribution. From Norway north of Lofoten south to the Mediterranean, extending into the Kattegat.

Occurrence. The Boreal and Lusitanian regions.

Habitat. From $80 \mathrm{~m}$ deep near the northern limits of its range to over $2000 \mathrm{~m}$ elsewhere on soft bottoms.

Subfossil finds. None.

\section{Admete viridula (Fabricius 1780)}

Distribution. Spitsbergen, E and W Greenland, around Iceland, empty shells from off the Faeroes, Norway from north of the Lofoten islands, and south to the northern borders of the North Sea. Included in the recent Danish fauna (Jensen \& Knudsen 1995).

Occurrence. The Arctic, Subarctic and Boreal regions.

Habitat. From a few metres to depths of $1000 \mathrm{~m}$, the greatest depths in the south of its range (Fretter \& Graham 1984, p. 507) on soft bottoms.

Subfossil finds. Recorded from the Early/Middle Weichselian (The Portlandia arctica zone in the Skærumhede sequence) in the Vendsyssel region.

\section{Subclass Heterobranchia} Order Heterostropha

\section{Omalogyra atomus (Philippi 1841)}

Distribution. W Greenland, around Iceland and Norway, south to the Mediterranean. Known from only a few places in Danish waters.

Occurrence. The Subarctic, Boreal and Lusitanian regions.

Habitat. From the lower part of the shore to a depth of $20 \mathrm{~m}$, occurring on seaweeds.

Only subfossil finds. The Limfjord region, Holocene.

\section{Brachystomia carozzai van Aartsen 1987}

Distribution. From the southern part of Norway (Spärck $\&$ Thorson 1931) and south to the Mediterranean. The species extends into the Kattegat and Limfjord. As commented on by Fretter et al. (1986, p. 605) and Jensen \& Knudsen (1995), the determination of these small snails living ectoparasitically on other marine organisms is still in progress, so the actual situation for the record of subfossil material should be taken with great precaution.

Occurrence. The Boreal and Lusitanian regions.

Habitat. From the tidal zone, where it occurs in crevices, to depths of about $70 \mathrm{~m}$.

Subfossil finds. None.

\section{Brachystomia eulimoides Hanley 1844}

Distribution. From Norway off the Lofoten islands and south to the Mediterranean. Recorded from the Limfjord, according to Jensen \& Knudsen (1995) the only Danish record, following Fretter et al. (1986, p. 602).

Occurrence. The Boreal and Lusitanian regions.

Habitat. Most frequently found on living animals of Pecten, Chlamys, oysters and Turritella to depths of $120 \mathrm{~m}$.

Subfossil finds. The Kattegat, Limfjord, North Sea and 
Vendsyssel regions, Holocene. From the North Sea region during the Eemian.

\section{Odostomia scalaris MacGillivray 1843}

Distribution. From southern Norway south to the Mediterranean. The species extends into the Limfjord, through the Kattegat, including the Øresund, and the Bælt Sea into the Kiel Bay (Fretter et al. 1986, p. 600).

Occurrence. The Boreal and Lusitanian regions.

Habitat. Associated primarily with banks of Mytilus edulis, but also recorded from other hosts (Fretter et al. 1986, p. 600).

Subfossil finds. The Limfjord and Vendsyssel regions, Holocene. From the Bælt Sea and North Sea during the Eemian.

\section{Chrysallida decussata (Montagu 1803)}

Fig. 32

Distribution. Mainly southern distribution, with the Shetlands as the northernmost post, but recorded from the Øresund (Jensen \& Knudsen 1995) and there are older records from east of Scotland (Fretter et al. 1986).

Occurrence. The Boreal and Lusitanian regions. Habitat. From 14 to $40 \mathrm{~m}$ deep on sandy and shelly bottoms.

Subfossilfinds. The Limfjord and Skagen areas, Holocene, in the Skagen Well recorded from the Subatlantic.

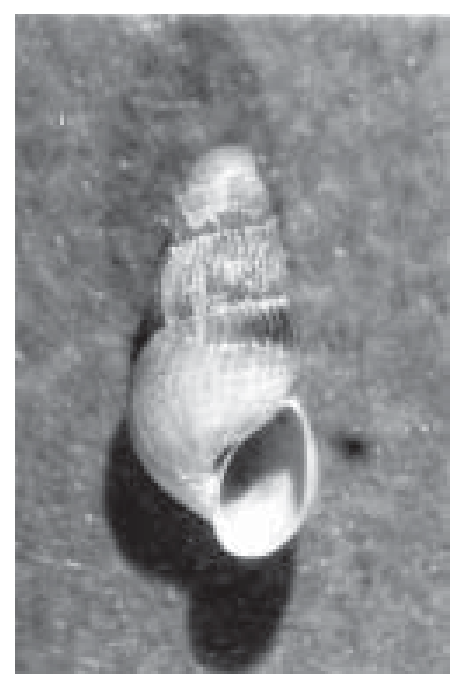

Fig. 32. Chrysallida decussata (Montagu 1803). Skagen 4, 15.0$15.5 \mathrm{~m}$ b.s., lab. no. 340,93. $\times 20$. MGUH 25342.

\section{Chrysallida eximia (Jeffreys 1849)}

Distribution. SW and NW Iceland, Norway north of Lofoten, and south to western Scotland. There is no record from Danish waters.

Occurrence. The Boreal and Lusitanian (northernmost) region.

Habitat. From 20 m to more than 1000 m, the greater depths in the southern part of its range, on soft gravelly bottoms.

Only subfossil finds. The Limfjord region, Holocene. From the Vendsyssel area during the Eemian.

\section{Chrysallida indistincta (Montagu 1808)}

Distribution. From Norway off the Lofoten islands (Thorson 1941) and south to the Mediterranean. It extends into the Kattegat and Øresund (Jensen \& Knudsen 1995), but is not recorded from the Limfjord (Petersen 1986a).

Occurrence. The Boreal and Lusitanian regions.

Habitat. From 7 to $100 \mathrm{~m}$ deep on sandy bottoms.

Subfossil finds. The Limfjord, North Sea and Vendsyssel areas, Holocene. Recorded from the North Sea during the Eemian.

\section{Chrysallida obtusa (Brown 1827)}

Distribution. From Norway off the Lofoten islands and south to the Mediterranean. The species extends into the Limfjord and through the Kattegat into the Øresund (Fretter et al. 1986, p. 562).

Occurrence. The Boreal and Lusitanian regions.

Habitat. From the tidal zone in rock pools to $90 \mathrm{~m}$ deep in stony places, associated with oysters (Fretter et al. 1986, p. 562).

Subfossil finds. The Limfjord and Vendsyssel regions, Holocene. From the Bælt Sea and North Sea regions during the Eemian. 


\section{Chrysallida spiralis (Montagu 1803)}

Distribution. From Norway north of Lofoten and south to the Mediterranean. According to Fretter et al. (1986, p. 574), the species extends into the Kattegat and Øresund, but it is absent from the Limfjord (Petersen 1986a).

Occurrence. The Boreal and Lusitanian regions.

Habitat. From the tidal zone to about $120 \mathrm{~m}$ deep, often abundant in the neighbourhood of tubes of sedentary polychaetes (Fretter et al. 1986).

Subfossil finds. The Kattegat, Limfjord, North Sea and Vendsyssel regions, Holocene. The Bxelt Sea, Kattegat, and North Sea regions during the Eemian.

\section{Ebala nitidissima (Montagu 1803)}

Distribution. From south of Norway to the Mediterranean. Recorded from the Kattegat region with fjords and the Øresund and the Bælt Sea regions as far as Kiel Bay (Fretter et al. 1986, p. 630), but absent from the Limfjord (Petersen 1986a).

Occurrence. The Boreal and Lusitanian regions.

Habitat. From 5 to $50 \mathrm{~m}$ deep on muddy sand or shelly bottoms.

Subfossil finds. The Limfjord and Vendsyssel regions, Holocene. From the Bælt Sea and North Sea areas during the Eemian.

\section{Eulimella laevis (Brown 1827)}

Distribution. From Norway off the Lofoten islands and south to the Mediterranean. It has not been recorded from Danish waters except the Øresund region (Jensen \& Knudsen 1995)

Occurrence. The Boreal and Lusitanian regions.

Habitat. From 20 to 400 m deep on muddy sand.

Subfossil finds. The Limfjord, North Sea and Vendsyssel regions, Holocene.

\section{Eulimella scillae (Scacchi 1835)}

Fig. 33

Distribution. From Norway off the Lofoten islands, but empty shells only off SW Iceland (Thorson 1941), and south to the Mediterranean. It extends into the Kattegat along the Swedish west coast (Fretter et al. 1986), but occurs in the Øresund (Jensen \& Knudsen 1995).

Occurrence. The Boreal and Lusitanian regions.

Habitat. From 20 to $400 \mathrm{~m}$ deep on muddy sand or sand.

Subfossil finds. The Limfjord and Skagen areas, Holocene, recorded in the Skagen Well from the Atlantic and Subboreal. From the Vendsyssel area found during the Eemian.

\section{Ondina divisa (J. Adams 1797)}

Distribution. From S and W Iceland, northern Norway (W Finmarken) (Thorson 1941) and south to the Biscay. The species extends through the Kattegat to the Øresund (Fretter et al. 1986, p. 582).

Occurrence. The Boreal and Lusitanian regions.

Habitat. From 18 to 200 m deep on sandy and gravelly mud.

Subfossil finds. The Limfjord region, Holocene. From the Vendsyssel area found during the Eemian.

Fig. 33. Eulimella scillae (Scacchi 1835). Skagen 3, $82.34-82.50 \mathrm{~m}$ b.s., lab. no. $729,93 . \times 9.6 . \mathrm{MGUH}$ 25343 .

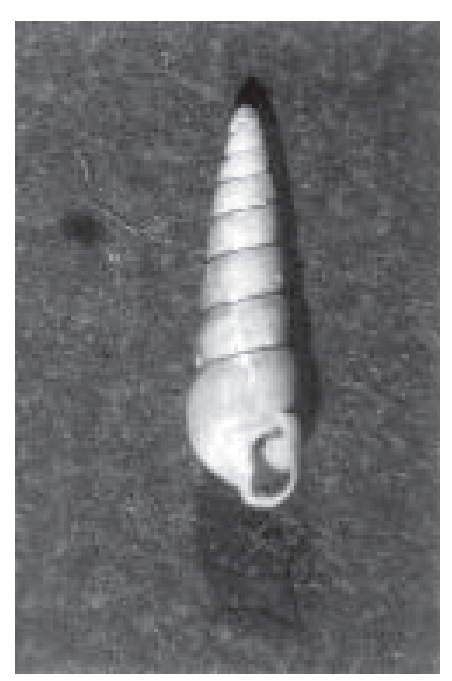




\section{Ondina obliqua (Alder 1884)}

Distribution. According to Fretter et al. (1986, p. 586) from southern Scandinavia to Biscay. However, Spärck \& Thorson (1931) only mentioned Scotland. Furthermore, only western localities have been reported from the British Isles (Fretter et al. 1986), and it is doubtful whether the Danish records actually refer to this species. Therefore, the species is here considered to be Lusitanian and should not be taken as present in the recent Danish fauna, although recorded by Jensen \& Knudsen (1995).

Habitat. From 30 to $60 \mathrm{~m}$ deep in gravelly or sandy mud.

Subfossil finds. None.

\section{Ondina diaphana (Jeffreys 1848)}

Distribution. According to Spärck \& Thorson (1931), present from southern Norway and south to the Mediterranean. In Danish waters the Kattegat and the Øresund.

Occurrence. The Boreal and Lusitanian regions.

Habitat. From 20 to $90 \mathrm{~m}$ deep on soft bottoms.

Subfossil finds. The Limfjord and North Sea regions, Holocene.

\section{Liostomia clavula (Lovén 1846)}

Distribution. From southern Norway south to the Mediterranean. Extends through the Kattegat to the Øresund (Jensen \& Knudsen 1995).

Occurrence. The Boreal and Lusitanian regions.

Habitat. From 30 to $90 \mathrm{~m}$ deep on soft bottoms associated with Pennatula (Fretter et al. 1986, p. 590).

Subfossil finds. None.

\section{Liostomia afzelii Warén 1991}

This species, newly established, will not be considered further.

\section{Odostomia acuta Jeffreys 1848}

Distribution. From Norway north of Lofoten and south to the Mediterranean. The species is found in the Skagerrak, Kattegat and Øresund (Fretter et al. 1986, p. 613).

Occurrence. The Boreal and Lusitanian regions.

Habitat. From 20 to $30 \mathrm{~m}$ deep. Perhaps associated with bryozoans.

Subfossil finds. The Limfjord region, Holocene.

\section{Odostomia conoidea Winckworth 1932}

Fig. 34

Distribution. From Norway off the Lofoten islands and south to the Mediterranean. Recorded from the Skagerrak (Fretter et al. 1986) and the Øresund (Jensen \& Knudsen 1995), but not from the Limfjord (Petersen 1986a).

Occurrence. The Boreal and Lusitanian regions.

Habitat. From 10 to $150 \mathrm{~m}$ deep, usually in association with the starfish Astropecten irregularis (Fretter et al. 1986, p. 617).

Subfossil finds. The Bælt Sea, Limfjord, North Sea, Vendsyssel and Skagen regions, Holocene. In the Skagen area recorded from the Subatlantic.

Fig. 34. Odostomia conoidea Winckworth 1932. Skagen 3, 48.90$49.10 \mathrm{~m}$ b.s., lab. no. 714,93. × 40. MGUH 25344 .

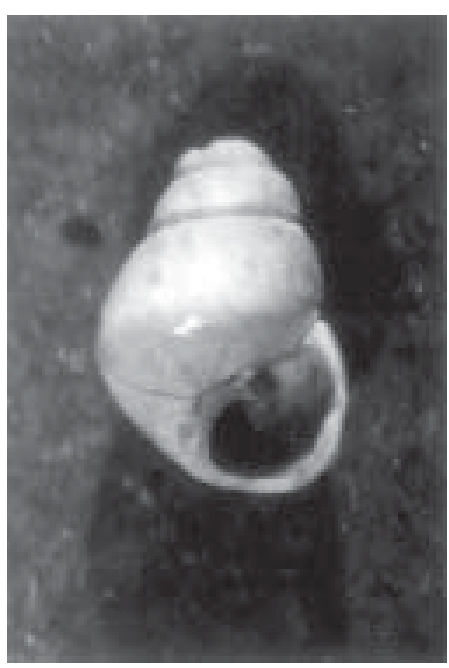




\section{Odostomia turrita Hanley 1844}

Distribution. From Norway north of Lofoten and south to the Mediterranean. The species extends through the Kattegat to the Øresund (Fretter et al. 1986, p. 612), but is not recorded from the Limfjord (Petersen 1986a).

Occurrence. The Boreal and Lusitanian regions.

Habitat. From the tidal zone to $100 \mathrm{~m}$ deep on weed and clay bottoms.

Subfossil finds. The Limfjord and Vendsyssel regions, Holocene. Recorded from the Vendsyssel area during the Eemian.

\section{Odostomia albella Lovén 1846}

Distribution. Empty shells recorded from Spitsbergen, SW and NW Iceland, Norway north of Lofoten and south to the Mediterranean. The species occurs in the Skagerrak (Fretter et al. 1986), the Øresund area (Jensen \& Knudsen 1995), and the Limfjord region (Petersen 1986a).

Occurrence. The Boreal and Lusitanian regions.

Habitat. From the tidal zone to depths of about $100 \mathrm{~m}$ on boulders, associated with growth of Pomatoceros (Fretter et al. 1986).

Subfossil finds. The Limfjord, North Sea and Vendsyssel regions, Holocene. From the North Sea region during the Eemian.

\section{Odostomia plicata (Montagu 1803)}

Distribution. From the southern part of Scandinavia (not southern Norway (Spärck \& Thorson 1931)) and south to the Mediterranean (Fretter et al. 1986, p. 610). The species extends into the Kattegat, including the Øresund (Jensen \& Knudsen 1995), but is not recorded from the Limfjord (Petersen 1986a).

Occurrence. The Boreal and Lusitanian regions.

Habitat. In the tidal zone associated with Pomatoceros triqueter (Fretter et al. 1986).

Subfossil finds. The Limfjord and Vendsyssel regions, Holocene.

\section{Odostomia umbilicaris (Malm 1863)}

Fig. 35

Distribution. From southern Norway (Spärck \& Thorson 1931) to the British Isles. The species extends to the Swedish west coast but not further into the Kattegat (Fretter et al. 1986, p. 620).

Occurrence. The Boreal and Lusitanian (northern part) regions.

Habitat. From 20 to $275 \mathrm{~m}$ deep, found on the bivalve Mytilus adriaticus (Fretter et al. 1986).

Subfossil finds. The Skagen area, Holocene, recorded from the Atlantic and Subatlantic.

\section{Turbonilla crenata (Brown 1827)}

Distribution. From Norway off the Lofoten islands (Thorson 1941) and south to the Mediterranean. The species extends into the Kattegat and Øresund (Fretter et al. 1986), but is absent from the Limfjord (Petersen 1986a).

Occurrence. The Boreal and Lusitanian regions.

Habitat. From 15 to $350 \mathrm{~m}$ deep on fine sand.

Subfossil finds. The Limfjord and North Sea regions, Holocene. Recorded from the Bælt Sea and North Sea during the Eemian.

Fig. 35. Odostomia umbilicaris (Malm 1863). Skagen 3, 82.34-82.50 m b.s., lab. no. $725,93 . \times 20$. MGUH 25345.

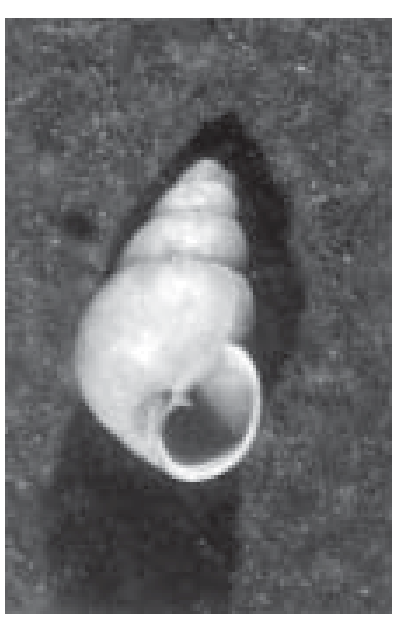




\section{Turbonilla delicata Monterosato 1884}

Fig. 36

Distribution. From the south-western part of the British Isles to the Mediterranean (Fretter et al. 1986, p. 636). However, recorded from the northern Kattegat and northern Øresund although, rare (Jensen \& Knudsen 1995).

Occurrence. The Boreal and Lusitanian regions.

Habitat. On soft bottoms, but at uncertain depths (Fretter et al. 1986, p. 636).

Subfossil finds. The Limfjord, North Sea and Skagen regions, Holocene. From the Skagen area recorded from the Subatlantic.

\section{Turbonilla lactea (Linnaeus 1758)}

Distribution. From northern Norway and south to the Mediterranean. Present although uncommon in Danish waters (Jensen \& Knudsen 1995).

Occurrence. The Boreal and Lusitanian regions.

Habitat. From the tidal zone to depths of about $80 \mathrm{~m}$, occurring under stones in silty places in the tidal zone and on soft, muddy and sandy bottoms sublittorally (Fretter et al. 1986, p. 634).

Subfossil finds. The Limfjord, North Sea and Vendsyssel regions, Holocene. Recorded from the Bælt Sea, Kattegat, and North Sea regions during the Eemian.

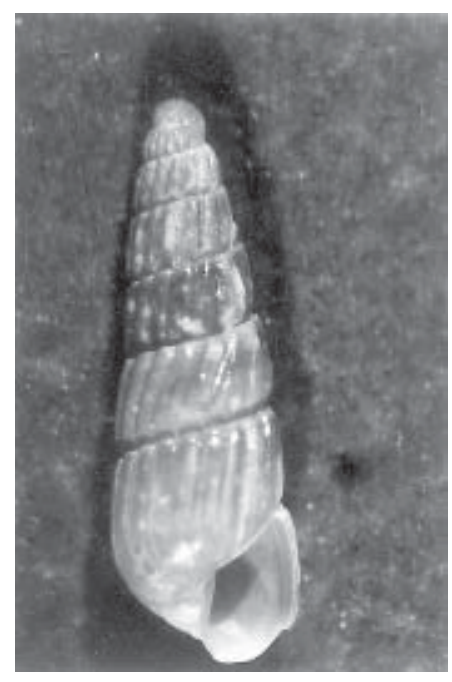

Fig. 36. Turbonilla delicata (Monterosato 1874). Skagen 4, 20.0$20.5 \mathrm{~m}$ b.s., lab. no. 345,93. $\times$ 20. MGUH 25346.

\section{Subclass Opisthobranchia Order Bullomorpha}

\section{Acteon tornatilis (Linnaeus 1758)}

Distribution. W and S Iceland, Norway off the Lofoten islands and south to the Mediterranean (Lemche 1938). The species extends into the Kattegat, including the Øresund (Petersen 1888, p. 78), but it is not recorded from the Limfjord (Petersen 1986a).

Occurrence. The Boreal and Lusitanian regions.

Habitat. From the intertidal zone down to $250 \mathrm{~m}$ in sand, usually in sheltered areas (Poppe \& Goto 1991, p. 192).

Subfossil finds. The Limfjord, North Sea and Vendsyssel regions, Holocene. Recorded from the North Sea and Vendsyssel areas during the Eemian.

\section{Haminoea navicula (da Costa 1778)}

Distribution. From the British Isles south to the Mediterranean.

Occurrence. The Lusitanian region.

Habitat. Lives in the Zostera beds in sheltered areas (Poppe \& Goto 1991, p. 196).

Only subfossil finds. The Brelt Sea, Kattegat, and North Sea regions during the Eemian.

\section{Cylichna cylindracea (Pennant 1777)}

Distribution. W and S Iceland, Norway off the Lofoten islands and south to the Mediterranean. The species extends into the Limfjord and Kattegat, including Øresund (Petersen 1888, p. 78; Jensen \& Knudsen 1995).

Occurrence. The Boreal and Lusitanian regions.

Habitat. From 40 to $200 \mathrm{~m}$ deep, in sand. According to Lemche (1938) associated with the Boreal Amphiura filiformis community in deeper water south of Iceland, corresponding to its occurrence in Danish waters.

Subfossil finds. The Limfjord and Vendsyssel regions, Holocene. 


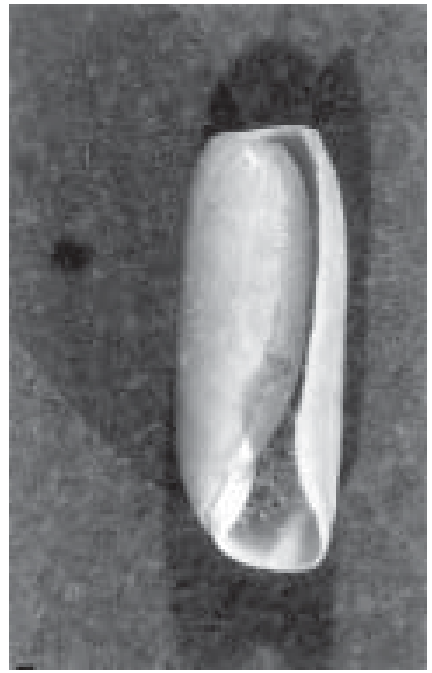

Fig. 37. Cylichna alba (Brown 1827). Skagen 3, 44.88-45.00 m b.s., lab. no. $499,93 . \times$ 9.6. MGUH 25347.

\section{Cylichna alba (Brown 1827)}

Fig. 37

Distribution. W and E Greenland, around Iceland, Norway north of Lofoten and south to the Bay of Biscay at greater depth (Lemche 1938, p. 9). The species extends into the North Sea and Skagerrak (Lemche 1928, p. 4).

Occurrence. The Arctic, Subarctic, Boreal and Lusitanian regions.

Habitat. According to Lemche (1928), this species is also widely distributed in depth, being found in low water to depths down to $2700 \mathrm{~m}$, on clay bottom (Faeroes).

Subfossil finds. The Limfjord, North Sea and Skagen areas, Holocene. In the Skagen Well recorded from the Subatlantic. Also found in the Vendsyssel area from the Early/Middle and Late Weichselian (the Older and Younger Yoldia Sea respectively).

\section{Cylicbna occulta (Mighels 1841)}

Distribution. E and W Greenland, N and E Iceland, Norway north of Lofoten (Lemche 1938).

Occurrence. The Arctic, Subarctic and Boreal (northernmost part) regions. Will be referred as an Arctic and Subarctic species.

Habitat. From 10 to 388 m deep (Iceland), especially found within the Macoma calcarea community, and might also occur within the Yoldia byperborea community (Lemche 1938).

Only subfossil finds. Recorded from the Kattegat region during the Early/Middle Weichselian and the Vendsyssel region during the Early/Middle and Late Weichselian (the Older and Younger Yoldia Sea respectively).

\section{Scaphander lignarius (Linnaeus 1758)}

Distribution. From S and W Iceland, the Faeroes, Norway off the Lofoten islands and south to the Mediterranean.

Occurrence. The Boreal and Lusitanian regions.

Habitat. From 60 to $700 \mathrm{~m}$ deep. The species is associated with the Boreal Spisula elliptica community on sandy plateaus south and west of Iceland (Lemche 1938, p. 7).

Subfossil finds. None.

\section{Scapbander punctostriatus (Mighels \& Adams 1841)}

Distribution. E and W Greenland, S and W Iceland, the Faeroes, Norway north of Lofoten and south to the Mediterranean.

Occurrence. The Arctic, Subarctic, Boreal and Lusitanian regions.

Habitat. Recorded from depths between 10 and 3000 $\mathrm{m}$, this probably having some relation to its wide horizontal distribution. Around the Faeroes the species may be expected to be found on the great, sandy plateaus (Lemche 1928, p. 4).

Subfossil finds. None.

\section{Pbiline aperta (Linnaeus 1767)}

Distribution. From the Faeroes, western Norway off Lofoten, and south to the Mediterranean (Lemche 1928). The species extends through Kattegat and Øresund, into the Bælt Sea as far as Kieler Bugt (Petersen 1888, p. 83), and it is also recorded from the Limfjord (Petersen 1986a). 
Occurrence. The Boreal and Lusitanian regions.

Habitat. The species prefers shallow water but has been found at depths down to $100 \mathrm{~m}$ off the Faeroes (Lemche 1928) on sandy bottoms. In Danish waters recorded from 10 to $30 \mathrm{~m}$, also on sandy bottoms (Petersen 1888).

Subfossil finds. The Limfjord and Vendsyssel regions, Holocene. Recorded from the Bælt Sea and the North Sea during the Eemian.

\section{Philine angulata Jeffreys 1867}

This species is mentioned by Jensen \& Knudsen (1995), but only on the basis of one broken shell found in the Zoological Museum in Copenhagen; difficult to identify; occurrence uncertain. So in the light of "the difficult problem of the relation between punctata and angulata", as treated by Lemche (1948, p. 67), this find will be omitted, also that no subfossil species have been found.

\section{Pbiline catena (Montagu 1803)}

Fig. 38

Distribution. From Norway off the Lofoten islands and south to the Mediterranean.

Occurrence. The Boreal and Lusitanian regions.

Habitat. From low water-mark to 76 m (Forbes \& Hanley 1853)

Subfossil finds. The Skagen region during the Eemian.

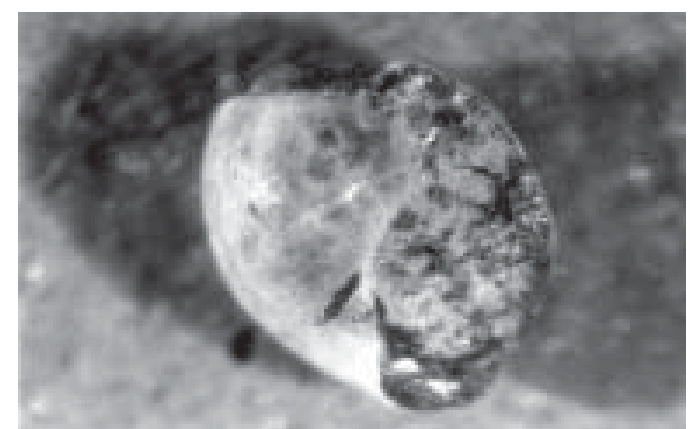

Fig. 38. Philine cf. catena (Montagu 1803). Skagen 3, 180.77180.89 m b.s., lab. no. 798,93. × 40. MGUH 25348.

\section{Pbiline denticulata (Adams 1800)}

Distribution. From Norway south to the Mediterranean.

Occurrence. The Boreal and Lusitanian regions.

Subfossil finds. None.

\section{Pbiline punctata (Adams 1800)}

Distribution. The Faeroes, southern part of the west coast of Norway, and south to the Mediterranean. Lemche (1928) also mentioned occurrences from Greenland, which, however, was not repeated in later papers (Lemche 1941a, b). Jensen \& Knudsen (1995) report occurrences from the Øresund, although rare, and Petersen (1888) has a single find from the Bælt Sea and Petersen (1986a) from the Limfjord.

Occurrence. The Boreal and Lusitanian regions.

Habitat. At the Faeroes the species is recorded from depths down to $240 \mathrm{~m}$ (Lemche 1928).

Subfossil finds. The Limfjord and Vendsyssel regions, Holocene.

\section{Philine quadrata (Wood 1839)}

Distribution. W Greenland, around Iceland, Norway north of Lofoten, and south to the Mediterranean. Recorded from the Øresund, but rare (Jensen \& Knudsen 1995).

Occurrence. The Subarctic, Boreal and Lusitanian regions.

Habitat. The vertical range of the species is about $35 \mathrm{~m}$ down to $2150 \mathrm{~m}$ (Lemche 1938).

Subfossil finds. None.

\section{Pbiline scabra (Müller 1776)}

Distribution. S and W Iceland, the Faeroes, Norway north of Lofoten, and south to the Mediterranean. The species extends into the Kattegat, including the Øresund (Petersen 1888, p. 84).

Occurrence. The Boreal and Lusitanian regions. 
Habitat. Off the coasts of W and S Iceland from 20$216 \mathrm{~m}$ on sandy bottom (Lemche 1938, p. 11); however, in Danish waters (Kattegat) from 20-40 m on mixed bottom (Petersen 1888, p. 84).

Subfossil finds. None.

\section{Philinoglossa belgolandica Hertling 1932}

Distribution. From the North Sea - Helgoland - and south to the Mediterranean, the species might occur in Danish waters (Jensen \& Knudsen 1995, p. 29).

Occurrence. The Boreal and Lusitanian regions.

Habitat. Probably in shell gravel (Jensen \& Knudsen 1995).

Subfossil finds. None.

\section{Order Anaspidea}

\section{Diaphana minuta Brown 1827}

Distribution. E and W Greenland, around Iceland, the Faeroes, Norway north of Lofoten, and south to the Mediterranean. The species extends into the Kattegat and Øresund (Petersen 1888; Jensen \& Knudsen 1995).

Occurrence. The Arctic, Subarctic, Boreal and Lusitanian regions.

Habitat. In general from the tidal zone to $770 \mathrm{~m}$, but is said to prefer sandy clay at depths of 20-40 m (Lemche 1928). This is very much the same as for the Kattegat, where Petersen (1888) says that the species prefers mixed bottom at a depth of about 19-38 m.

Subfossil finds. The Limfjord and Vendsyssel regions, Holocene.

\section{Retusa obtusa (Montagu 1803)}

Distribution. E and W Greenland, around Iceland, the Faeroes, Norway north of Lofoten, and south to the British Isles (Shetland and Scotland) (Lemche 1928). The species is found in the Limfjord and is common in the fjords and bays bordering the Kattegat, including the Øresund, and extends into the Bælt Sea and the western part of the Baltic (Petersen 1888, p. 81).
Occurrence. The Arctic, Subarctic and Boreal regions.

Habitat. From the intertidal zone down to $300 \mathrm{~m}$ deep in mud or fine sand. In Danish waters Petersen (1888) points to the observed differences in depth, i.e. in the Kattegat region around $20 \mathrm{~m}$ while $60 \mathrm{~m}$ deep in the Baltic. The species is connected with the Arctic $\mathrm{Ma}$ coma community (Lemche 1941a, b).

Subfossil finds. The Bælt Sea, Kattegat, Limfjord, North Sea and Vendsyssel regions, Holocene. Also recorded from the Vendsyssel area during the Early/Middle Weichselian and the Late Weichselian (the Older Yoldia Sea and the Younger Yoldia Sea respectively).

\section{Retusa truncatula (Bruguière 1792)}

Fig. 39

Distribution. The Faeroes, Norway north of Lofoten, and south to the Mediterranean (Lemche 1928, 1938). The species extends through the Kattegat, including the Øresund, and into the Bælt Sea, and it is also recorded from the Limfjord (Petersen 1888, p. 80).

Occurrence. The Boreal and Lusitanian regions.

Habitat. In general the species lives from the tidal zone down to $200 \mathrm{~m}$ (Poppe \& Goto 1991). However, in Danish waters, according to Petersen (1888), it lives in shallow water down to only about $20 \mathrm{~m}$ deep on sandy bottoms with Zostera.

Subfossil finds. The Bælt Sea, Baltic, Kattegat, Limfjord, North Sea, Vendsyssel and Skagen regions, Holocene.

Fig. 39. Retusa truncatula (Bruguière 1792). Skagen 3, 67.34-67.39 m b.s., core sample K-25. × 9.6. MGUH 25349.

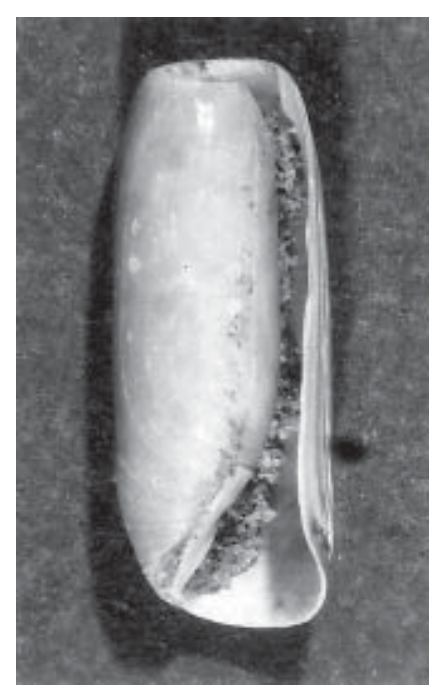


Recorded from the Skagen area from the Subboreal and Subatlantic. From the Bælt Sea and the North Sea recorded during the Eemian.

\section{Retusa umbilicata (Montagu 1803)}

Fig. 40

Distribution. From Norway north of Lofoten (Lemche 1928) and south to the Mediterranean (Poppe \& Goto 1991). The species extends into the Kattegat and Øresund (Petersen 1888; Jensen \& Knudsen 1995), but is not recorded from the Limfjord (Petersen 1986a).

Occurrence. The Boreal and Lusitanian regions.

Habitat. From depths of about 20 to $30 \mathrm{~m}$ on mixed bottoms (Petersen 1888).

Subfossil finds. The Limfjord, North Sea, Vendsyssel and Skagen regions, Holocene. From the Skagen Well recorded from the Subboreal and Subatlantic. From the Bælt Sea, North Sea, and Vendsyssel regions found during the Eemian.

\section{Rbizorus acuminatus (Bruguière 1792)}

Distribution. From western and southern Norway south to the Mediterranean, in Danish waters from the southern Kattegat.

Occurrence. The Boreal and Lusitanian regions.

Habitat. From the tidal zone to 800 m deep.

Subfossil finds. None.

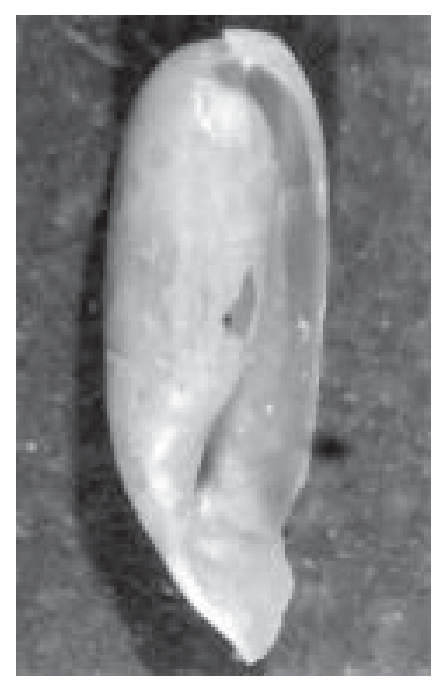

Fig. 40. Retusa umbilicata (Montagu 1803). Skagen 3, 70.10-70.30 m b.s., lab. no. $721,95 . \times 20$. MGUH 25350 .

\section{Akera bullata O.F. Müller 1776}

Distribution. The Faeroes, Norway north of Lofoten, and south to the Mediterranean (Lemche 1928). The species extends into the Limfjord, the Kattegat, including the Øresund, and the Bælt Sea as far as the Kieler Bugt (Petersen 1888).

Occurrence. The Boreal and Lusitanian regions.

Habitat. In sheltered bays down to $370 \mathrm{~m}$ deep (Poppe \& Goto 1991). Common in shallow water with Zostera (Petersen 1888).

Subfossil finds. The Bælt Sea, Kattegat, Limfjord and Vendsyssel regions, Holocene. In the Bælt Sea and Kattegat regions recorded from the Eemian.

\section{Order Thecosomata}

\section{Limacina retroversa (Fleming 1823)}

Fig. 41

Distribution. E and W Greenland, around Iceland, Norway north of Lofoten, and south to Ireland (Lemche 1938). It is common in the North Sea and Skagerrak, penetrating into the Kattegat, occasionally even into the Brelt Sea (Kramp 1961).

Occurrence. The Arctic, Subarctic, Boreal and Lusitanian (northernmost) regions.

Habitat. Pelagic.

Subfossil finds. Recorded from the Vendsyssel and Skagen regions during the Eemian and from the Vendsyssel region during the Late Weichselian (the Younger Yoldia Sea).

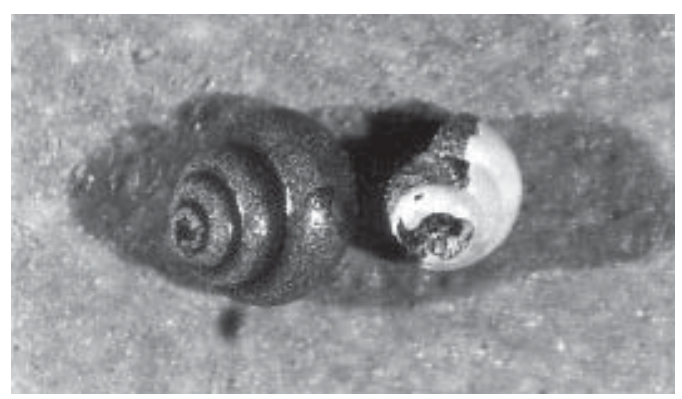

Fig. 41. Limacina retroversa (Fleming 1823). Skagen 3, 180.57180.70 m b.s., lab. no. 797,93. × 20. MGUH 25351. 


\section{Order Gymnosomata}

\section{Clione limacina (Phipps 1774)}

Fig. 42

Distribution. E and W Greenland, around Iceland, the Faeroes, Norway north of Lofoten (Lemche 1938), and south to the west coast of England. Common in the northern part of the North Sea and in the Skagerrak, occasionally penetrating into the Kattegat (Kramp 1961). Rare occurrences in the Øresund (Jensen \& Knudsen 1995).

Occurrence. The Arctic, Subarctic, Boreal and Lusitanian (northern part) regions.

Habitat. Pelagic.

Subfossil finds. Recorded (imprint) from the Skagen Well during the Late Weichselian (the Younger Yoldia Sea).

\section{Subclass Pulmonata Order Basommatophora}

\section{Ovatella myosotis (Draparnaud 1801)}

Distribution. From Scandinavia along the coast of western Europe, south to the Mediterranean (Steenberg 1911, p. 204). In Danish waters recorded from the Bæelt Sea and the Baltic (Jensen \& Knudsen 1995).

Occurrence. The Boreal and Lusitanian regions.

Habitat. Lives on sea wrack along the coasts (Steenberg 1911).

Subfossil finds. None.

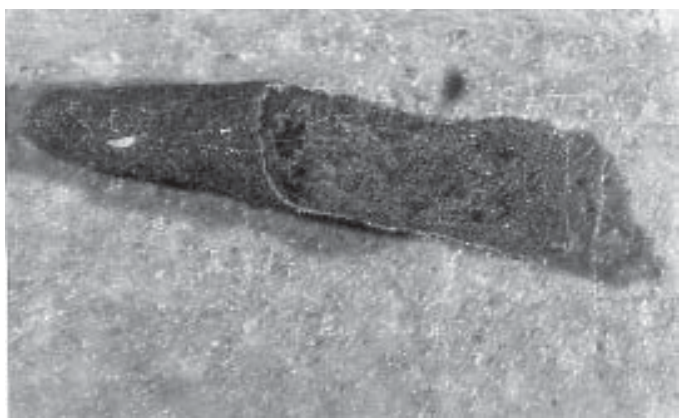

Fig. 42. Clione limacina (Phipps 1774). Skagen 3, 115.07-115.15 m b.s., lab. no. 749,93. × 20. MGUH 25352.

\section{Lymnaea (Radix) peregra (Müller 1774) f. baltica} Linné

Distribution. Lymnaea peregra is found all over Europe: Iceland, the Faeroes, Norway north of Lofoten, and south to the Mediterranean (Mandahl-Barth 1938). The species occurs in the Baltic and southern Øresund (Jensen \& Knudsen 1995).

Occurrence. The Boreal and Lusitanian regions.

Habitat. Lymnaea peregra f. baltica Linné and L. p. f. succinea Nilsson are brackish water forms tolerating up to 8\% salt (Mandahl-Barth 1949, p. 74).

Subfossil finds. The Bælt Sea and Baltic regions, Holocene.

\section{Class Scaphopoda Order Siphonodentalioida}

\section{Cadulus subfusiforme (M. Sars 1865)}

Fig. 43

Distribution. Western Iceland, the Faeroes, Norway north of Lofoten, and south to the Mediterranean (Knudsen 1949b). In Danish waters taken in the Skagerrak (Muus 1959).

Occurrence. The Boreal and Lusitanian regions.

Habitat. From 80 to 1300 m deep on mud bottoms. In Danish waters at a depth of $230 \mathrm{~m}$ on clay bottom (Muus 1959).

Subfossil finds. Recorded from the Skagen Well during the Eemian.

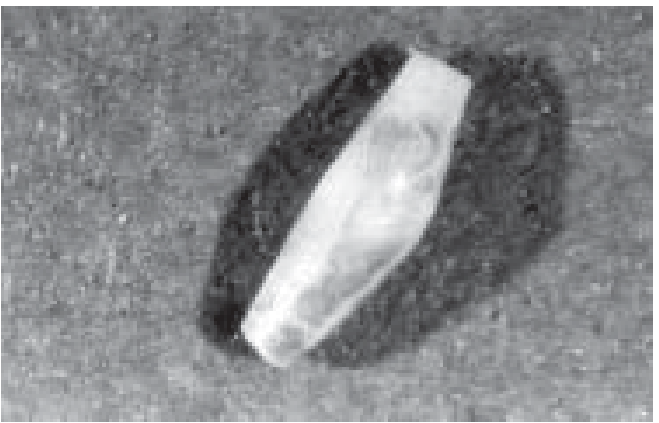

Fig. 43. Cadulus subfusiforme (M. Sars 1865). Skagen 3, 180.77180.89 m b.s., lab. no. 798,93. × 20. MGUH 25353. 


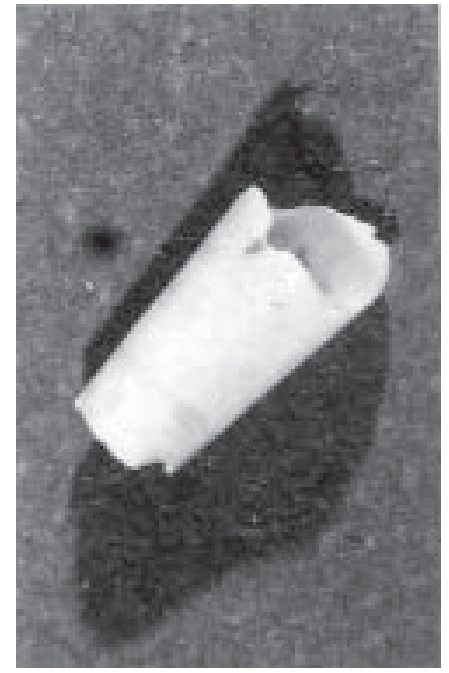

Fig. 44. Siphonodentalium lobatum (Sowerby 1860). Skagen 3, 114.64-? m b.s., core sample K-57. $\times$ 9.6. MGUH 25354.
Siphonodentalium lobatum (Sowerby 1860)

Fig. 44

Distribution. E and W Greenland, N and E Iceland (Knudsen 1949b), the Faeroes, Norway north of Lofoten, and south to Portugal. The species might be found in Norske Rende. In Norway often found in glacial deposits (Muus 1959).

Occurrence. The main areas are the Arctic, Subarctic and Boreal regions, but the species extends into the Lusitanian region.

Habitat. From 36 to 3116 m on mud (Knudsen 1949b).

Only subfossil finds. Recorded from the Skagen Well in the Late Weichselian (the Younger Yoldia Sea) and from the Eemian.

\section{Entalina tetragona (Brocchi 1814)}

Fig. 45

Distribution. From northern Norway south to the Bay of Biscay and the Mediterranean. From Danish waters in the North Sea and Skagerrak (Muus 1959).

Occurrence. The Boreal and Lusitanian regions.

Habitat. It is a deep-water species preferring mud bottoms (Poppe \& Goto 1993). In the Danish waters known from 100 to 480 m on mixed bottom (Muus 1959) connected with the Amphilipis norvegica/Pecten vitreus community at depths of 250-700 m.

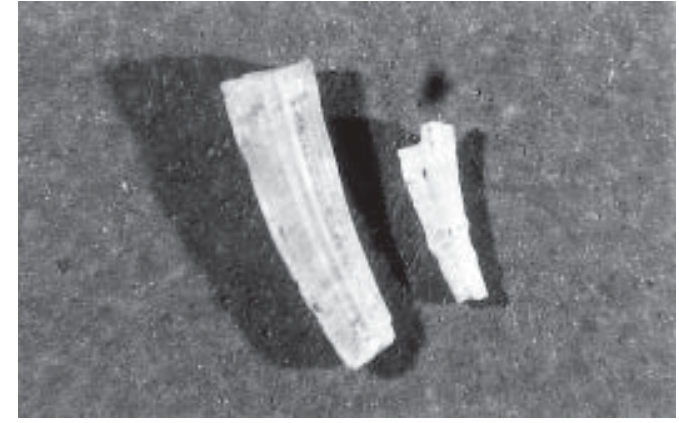

Fig. 45. Entalina tetragona (Brocchi 1814). Skagen 3, 183.77184.00 m b.s., lab. no. 799,93. × 9.6. MGUH 25355.

Subfossil finds. Recorded from the Skagen Well during the Eemian.

\section{Order Dentalioida}

\section{Antalis agile G.O. Sars 1878}

Distribution. S and W Iceland, Norway off the Lofoten islands, and south to the Mediterranean. In the Danish waters the species extends from the North Sea into the Skagerrak and Kattegat.

Occurrence. The Boreal and Lusitanian regions.

Habitat. From $55 \mathrm{~m}$ down to $1250 \mathrm{~m}$. In Scandinavian waters rarely at depths less than $70 \mathrm{~m}$ (Muus 1959).

\section{Subfossil finds. None.}

\section{Antalis entalis (Linnaeus 1758)}

Distribution. W Greenland, Iceland, the Faeroes, Norway north of Lofoten, and south to the Mediterranean (Knudsen 1949b). Common in the Danish waters, extending into the Kattegat (Muus 1959) although rare in the Øresund (Jensen \& Knudsen 1995).

Occurrence. The Subarctic, Boreal and Lusitanian regions.

Habitat. From 20 to $400 \mathrm{~m}$ in the Kattegat region, and in the North Sea between 30 and 200 m (Muus 1959). However, the vertical range in general goes from 63200 m (Knudsen 1949b).

Subfossil finds. The Skagen Well during the Eemian. 


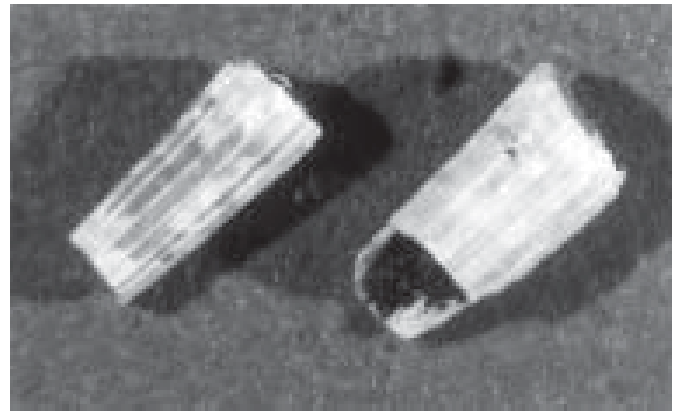

Fig. 46. Dentalium vulgare da Costa 1778. Skagen 3, 181.17181.21 m b.s., core sample K-99. × 9.6. MGUH 25356.

\section{Dentalium vulgare da Costa 1778}

Fig. 46

Distribution. From the British Isles and south to the Mediterranean. Might be found in the southern North Sea.

Occurrence. Mainly the Lusitanian region.

Habitat. Sublittorally from $1 \mathrm{~m}$ and down to $50 \mathrm{~m}$ on mud and sandy bottoms.

Only subfossil finds. Recorded from the Skagen Well during the Eemian.

\section{Class Bivalvia}

\section{Subclass Palaeotaxodonta}

Order Nuculoida

\section{Nucula nitidosa Winckworth 1930}

Fig. 47

Distribution. From Norway off the Lofoten islands and

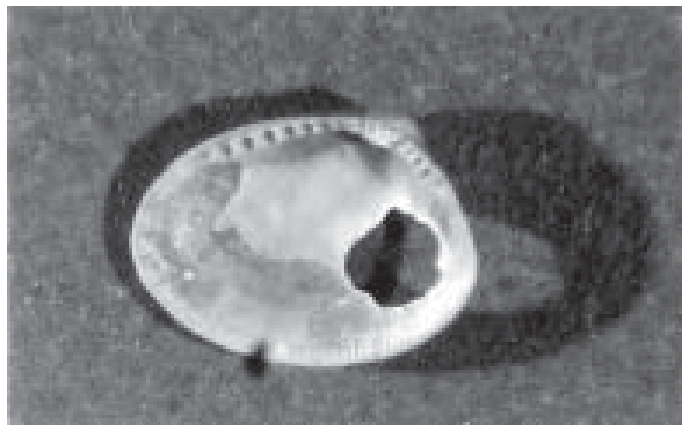

Fig. 47. Nucula nitidosa Winckworth 1930. Skagen 4, 21.0-21.5 m b.s., lab. no. 346,93. × 9.6. Right valve. MGUH 25357. south to the Mediterranean (Madsen 1949). The species extends from the more shallow part of the North Sea and Skagerrak into the Kattegat, including the Øresund. Very common in the western part of the Limfjord (Jensen \& Spärck 1934, p. 23).

Occurrence. The Boreal and Lusitanian regions.

Habitat. In general from 7 to $250 \mathrm{~m}$ deep on fine sand or sand/mud bottoms (Poppe \& Goto 1993). However, according to Jensen \& Spärck (1934) the species is often found at depths of 6-10 $\mathrm{m}$ in the Limfjord and $10-30 \mathrm{~m}$ in the Kattegat region.

Subfossil finds. The Limfjord, North Sea, Vendsyssel and Skagen regions, Holocene. From the Skagen Well recorded from the Subatlantic. During the Eemian found in the Bælt Sea, Baltic and North Sea regions.

\section{Nucula nucleus (Linnaeus 1767)}

Fig. 48

Distribution. From Norway off the Lofoten islands, the Faeroes, and south to the Mediterranean (Madsen 1949). Posselt \& Jensen (1898) have but few records from West Greenland. The species extends from the North Sea into the Kattegat, including the Øresund (Jensen \& Spärck 1934), and is recorded from the Limfjord (Petersen 1986a).

Occurrence. The Boreal and Lusitanian regions.

Habitat. Lives from the tidal zone down to $150 \mathrm{~m}$ on gravel and mud bottoms. In Danish waters common between 20 and $100 \mathrm{~m}$.

Subfossil finds. The Limfjord, North Sea, Vendsyssel

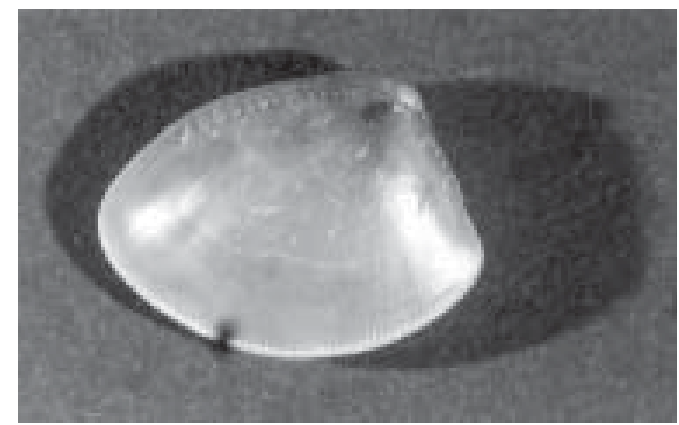

Fig. 48. Nucula nucleus (Linnaeus 1767). Skagen 4, 9.0-9.5 m b.s., lab. no. 334,93. × 4.8. Right valve. MGUH 25358. 
and Skagen regions, Holocene. Recorded in the Skagen Well from the Subatlantic. In the Eemian recorded from the Baltic and Vendsyssel regions.

\section{Nucula sulcata (Bronn 1831)}

Distribution. Norway off the Lofoten islands and south to the Mediterranean. In Danish waters common in the deeper parts of the Kattegat and Øresund (Jensen \& Knudsen 1995), and it is also recorded from the Limfjord (Petersen 1986a).

Occurrence. The Boreal and Lusitanian regions.

Habitat. From 10 to $400 \mathrm{~m}$ deep, on mud or clay bottoms, and down to $2250 \mathrm{~m}$ (Poppe \& Goto 1993). In Kattegat from 50 to $100 \mathrm{~m}$ deep on silty bottom (Jensen \& Spärck 1934).

Subfossil finds. The North Sea, Holocene. From the Bælt Sea, North Sea and Vendsyssel regions recorded from the Eemian.

\section{Nuculoma banleyi Winckworth 1931}

Distribution. From the British Isles south to Spain (Poppe \& Goto 1993). Recorded from the northern Kattegat (Jensen \& Knudsen 1995).

Occurrence. The Boreal and Lusitanian regions.

Habitat. From 30 to $90 \mathrm{~m}$ deep on mud and gravel bottoms.

Subfossil finds. None.

\section{Nuculoma tenuis (Montagu 1808)}

Distribution. W and E Greenland, Spitsbergen, around Iceland, the Faeroes, Norway north of Lofoten, and south to the Mediterranean (Madsen 1949). The species extends from the deeper part of the Skagerrak into the Kattegat, Øresund, and Bælt Sea (Jensen \& Spärck 1934).

Occurrence. The Arctic, Subarctic, Boreal and Lusitanian regions.

Habitat. From off-shore down to $300 \mathrm{~m}$ on muddy bottoms (Poppe \& Goto 1993). The species is more littoral in the northern latitudes than in the south (Jensen \& Spärck 1934).

Subfossil finds. From the Limfjord and North Sea regions, Holocene. Recorded from the Vendsyssel area during the Eemian, and from the Kattegat and Vendsyssel area during the Early/Middle Weichselian (the Older Yoldia Sea), and furthermore from the Vendsyssel region during the Late Weichselian (the Younger Yoldia Sea).

\section{Nuculana minuta (Müller 1776)}

Fig. 49

Distribution. SE and W Greenland, around Iceland, the Faeroes, Norway north of Lofoten, and south to the British Isles. According to Ockelmann (1958), lacking in the most high-Arctic seas. In south-western Europe only at depths greater than $400 \mathrm{~m}$ (Madsen 1949). The species extends from the North Sea and Skagerrak into the Kattegat and Øresund (Jensen \& Spärck 1934).

Occurrence. The Subarctic and Boreal regions.

Habitat. From 10 to $190 \mathrm{~m}$. However, recorded from $2000 \mathrm{~m}$ on mud, sand and gravel bottoms (Poppe \& Goto 1993). In Danish waters common on silty bottom (Jensen \& Spärck 1934).

Subfossil finds. The Skagen region, Holocene. Recorded from the Skagen Well during the Subboreal and Subatlantic. From the Vendsyssel region found during the Eemian and in the Skagen area during the Late Weichselian (the Younger Yoldia Sea).

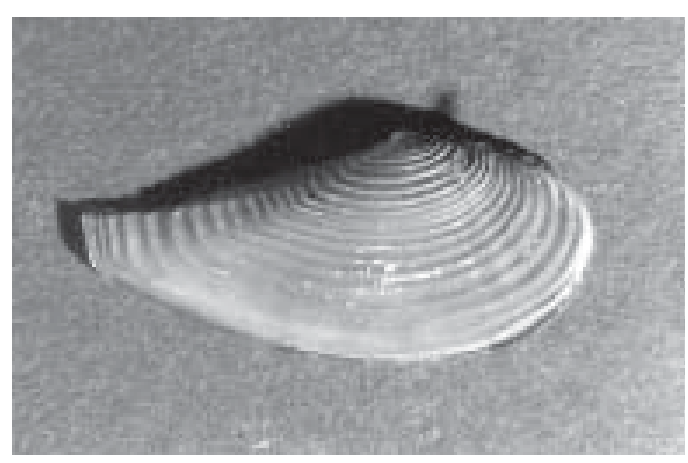

Fig. 49. Nuculana minuta (Müller 1776). GEUS collection. Læsø, Denmark. $\times$ 4.8. Right valve. MGUH 25359. 


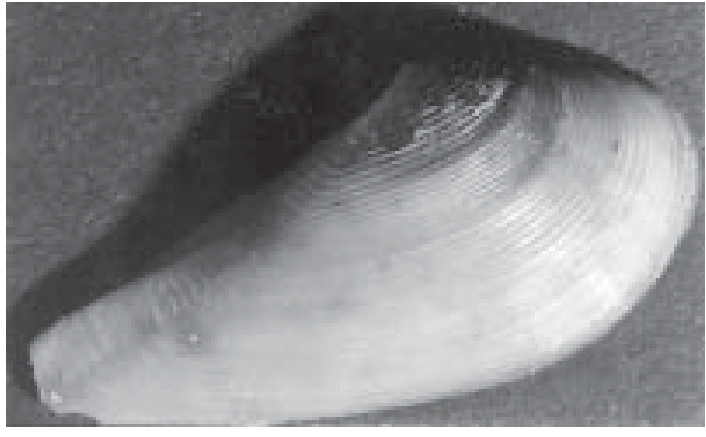

Fig. 50. Nuculana pernula (Müller 1776). GEUS collection. Læs $\varnothing$, Denmark. × 4.8. Right valve. MGUH 25360 .

\section{Nuculana pernula (Müller 1776)}

Fig. 50

Distribution. E and W Greenland, around Iceland, the Faeroes, Norway north of Lofoten, and south to the Bay of Biscay. However, in SW Europe only at depths greater than $400 \mathrm{~m}$ (Madsen 1949). In Danish waters the species extends from the North Sea, Skagerrak, and into the Kattegat, Øresund, and Bælt Sea region north of Femern (Jensen \& Spärck 1934).

Occurrence. The Arctic, Subarctic and Boreal regions.

Habitat. Lives off-shore between 80 and $900 \mathrm{~m}$ deep, especially in mud bottoms (Poppe \& Goto 1993). However, in Danish waters the species is found from a depth of $20 \mathrm{~m}$ (Kattegat) to $200 \mathrm{~m}$ (Skagerrak) according to Jensen \& Spärck (1934), and in the Arctic (East Greenland) from 3-9 m (Ockelmann 1958), being mostly littoral in the Arctic.

Subfossil finds. Recorded from the Vendsyssel and Skagen regions during the Eemian. From the Kattegat, Vendsyssel and Skagen regions during the Early and Middle Weichselian (the Older Yoldia Sea). From the Vendsyssel and Skagen regions during the Late Weichselian (the Younger Yoldia Sea).

\section{Yoldia byperborea Lovén 1859}

Fig. 51

Distribution. E and W Greenland, Spitsbergen, around Iceland and Norway north of Lofoten (Madsen 1949).

Occurrence. The Arctic, Subarctic and Boreal (northern part - High-Boreal) regions.

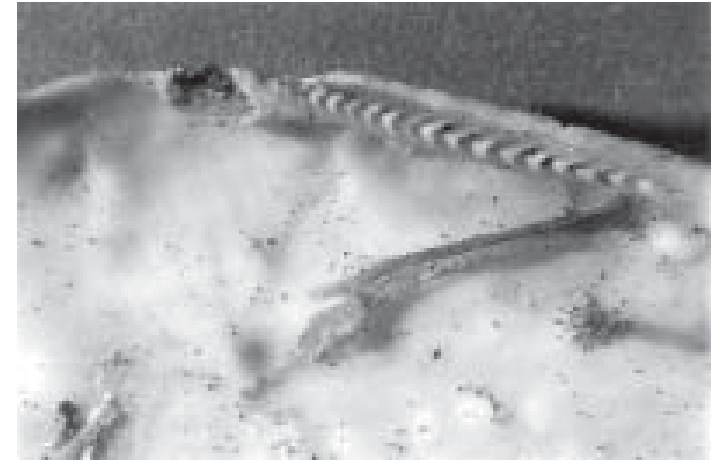

Fig. 51. Yoldia hyperborea Lovén 1859. GEUS collection. Nordre Strømfjord, Greenland. × 4.8. Right valve. MGUH 25361.

Habitat. From about 5 to $675 \mathrm{~m}$ on clay or mud, in few cases sand (Madsen 1949).

Only subfossilfinds. Recorded from the Vendsyssel and Skagen areas during the Early and Middle Weichselian (the Older Yoldia Sea) and from the Skagen Well also during the Late Weichselian (the Younger Yoldia Sea).

\section{Portlandia arctica (Gray 1824)}

Fig. 52

Distribution. According to Ockelmann (1958, p. 26): "Widely distributed in high-Arctic seas".

Occurrence. North Greenland, East Greenland, Spitsbergen, the Barents Sea, Novaya Zemlya, the Kara Sea, The Siberian Ice Sea, viz: Arctic and Subarctic regions.

Habitat. From $2 \mathrm{~m}$ to $340 \mathrm{~m}$ deep, however, the species is most common at depths between 10 and $50 \mathrm{~m}$ on a muddy or clayey bottom (Ockelmann 1958, p. 25).

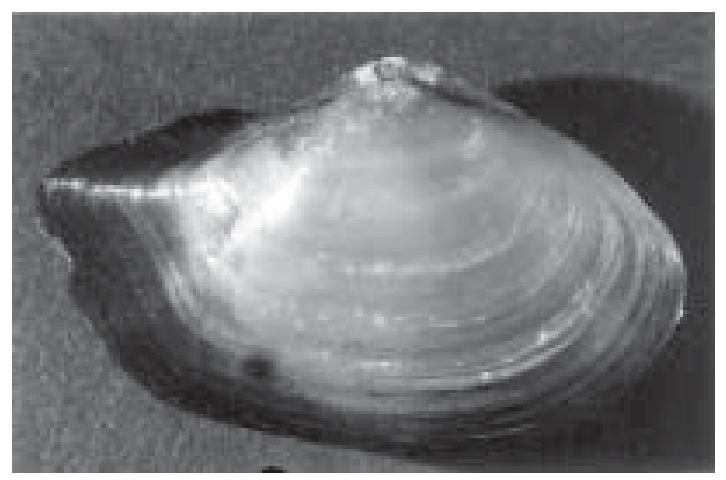

Fig. 52. Portlandia arctica (Gray 1824). GEUS collection. Disko, Greenland, $46 \mathrm{~m}$ a.s.l. $\times$ 4.8. Specimen seen from the right. MGUH 25362. 
Only subfossil finds. Recorded from the Kattegat, Vendsyssel, and Skagen areas during the Early and Middle Weichselian (the Older Yoldia Sea) and from the same areas during the late Weichselian (the Younger Yoldia Sea).

\section{Yoldiella lucida (Lovén 1846)}

Distribution. W Greenland, around Iceland, Norway north of Lofoten (Madsen 1949), and south over the British Isles to the Mediterranean. In the Danish waters found in the deeper part of the Skagerrak (Jensen \& Spärck 1934).

Occurrence. The Subarctic, Boreal and Lusitanian regions.

Habitat. From about $20 \mathrm{~m}$ to about $1400 \mathrm{~m}$ (Iceland), in the Skagerrak from about $200 \mathrm{~m}$ to more than $600 \mathrm{~m}$ on clayey bottoms.

Subfossil finds. From the Vendsyssel area during the Eemian.

\section{Yoldiella lenticula (Möller 1842)}

Fig. 53

Distribution. E and W Greenland, Spitsbergen, Siberian Sea, Norway north of the Lofoten Islands, south to the British Isles. Further south only at depths greater than 400 m (Madsen 1949).

Occurrence. The Arctic, Subarctic and Boreal regions.

Habitat. Most common at depths between 20 and 200 $\mathrm{m}$ (East Greenland) on rather pure clay or mud (Ockelmann 1958).

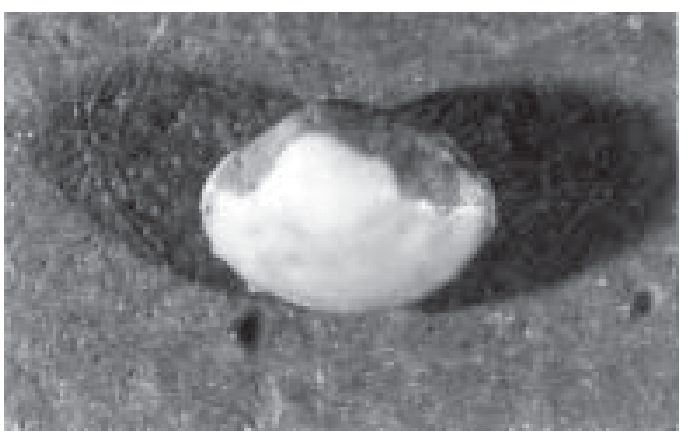

Fig. 53. Yoldiella lenticula (Möller 1842). Skagen 3, 121.39$121.50 \mathrm{~m}$ b.s., lab. no. $759,93 . \times 20$. Specimen seen from the left. MGUH 25363.
Only subfossil finds. Recorded from the Vendsyssel area during the Eemian, Early/Middle Weichselian (the Older Yoldia Sea) and Late Weichselian (the Younger Yoldia Sea). Found in the Skagen area from the Late Weichselian (the Younger Yoldia Sea).

\section{Yoldiella frigida (Torell 1859)}

Fig. 54

Distribution. E and W Greenland, Spitsbergen, around Iceland, Norway from north of Lofoten, and south to the Mediterranean (Madsen 1949). In the Danish waters found in the deeper parts of the Skagerrak (Jensen \& Spärck 1934). However, this is questioned by Ockelmann (1958), who says that the main distribution is high-Arctic and therefore the recent finds in Danish waters should be referable to Yoldiella nana. However, according to the old information, the species must have a wide distribution.

Occurrence. The Arctic and Subarctic regions, Boreal and Lusitanian.

Habitat. Most common at depths between 30 and 150 $\mathrm{m}$ on bottoms consisting of clay, mud, and clay mixed with sand and gravel (Ockelmann 1958).

Subfossil finds. Following the distribution of Portlandia frigida sensu Jensen \& Spärck (1934), the species has been recorded from the Vendsyssel and Skagen areas during the Eemian and from the Early and Middle Weichselian (the Older Yoldia Sea) and the Late Weichselian (the Younger Yoldia Sea).

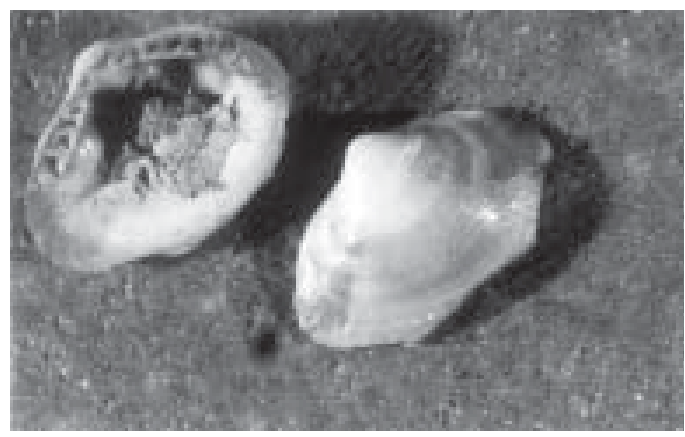

Fig. 54. Yoldiella frigida (Torell 1859). Skagen 3, 127.39-127.50 $\mathrm{m}$ b.s., lab. no. $763,93 . \times 20$. Specimen seen from the right. MGUH 25364. 


\section{Yoldiella pbilippiana (Nyst 1845)}

Distribution. From Norway off the Lofoten islands and south to the Mediterranean.

Occurrence. The Boreal and Lusitanian regions.

Habitat. Lives to a depth of about $135 \mathrm{~m}$ (Poppe \& Goto 1993); however, found at depths of $2500 \mathrm{~m}$ (Jensen \& Spärck 1934).

Only subfossil finds. Recorded from the Vendsyssel area during the Eemian.

\section{Yoldiella nana (M. Sars 1846)}

Distribution. Considering the discussion by Ockelmann (1958) on distinguishing between Portlandia frigida and Yoldiella nana, where the latter "at least in part" should be referable to P. fraterna, it is not possible to give any information on the distribution of Yoldiella nana mentioned by Jensen \& Knudsen (1995) as being part of the recent Danish fauna.

Subfossil finds. None.

\section{Malletia obtusa (G.O. Sars 1872)}

Distribution. From Norway off the Lofoten islands and south to SW Europe. The occurrences around the British Isles and in the Mediterranean are at depths greater than $400 \mathrm{~m}$ (Madsen 1949).

Occurrence. The Boreal and Lusitanian regions.

Habitat. This species has a wide range of depths according to Madsen (op. cit.) from 20-3200 m deep. In Danish waters only from the deeper part (>300 m), and in the Skagerrak mostly at a depth of $600 \mathrm{~m}$ (Jensen \& Spärck 1934).

Subfossil finds. None.

\section{Subclass Pteriomorphia Order Arcoida}

Acar nodulosa (Müller 1766)

Distribution. S and W Iceland, the Faeroes, Norway north of Lofoten, and south to the Mediterranean. The species has been taken on the Dogger Bank, but not in the inner Danish waters.

Occurrence. The Boreal and Lusitanian regions.

Habitat. From the tidal zone down to $1000 \mathrm{~m}$ fixed with its byssus to hard substrates (Poppe \& Goto 1993).

Subfossil finds. None.

\section{Batbyarca glacialis (Gray 1824)}

Fig. 55

Distribution. W and E Greenland, Spitsbergen, and around Iceland. The occurrences from SW Europe are of dead shells and from deep water (Ockelmann 1958).

Occurrence. Mainly the Arctic and Subarctic regions; however, the occurrences from southern Iceland imply extension into the Boreal region as well.

Habitat. From 6-10 m down to $425 \mathrm{~m}$ (East Greenland), but most abundant below $40 \mathrm{~m}$ on clay bottoms with stones and gravel, where the Astarte crenata community occurs.

Only subfossil finds. Recorded from the Vendsyssel (not in the Skærumhede sequence) and Skagen regions during the Early/Middle Weichselian and the Late Weichselian respectively.

\section{Batbyarca pectunculoides (Scacchi 1834)}

Distribution. W and E Greenland, around Iceland, Norway north of Lofoten, and south to the Mediterranean. In the Danish waters the species is rather common in the deeper part of the Skagerrak between 300-700 m (Jensen \& Spärck 1934).

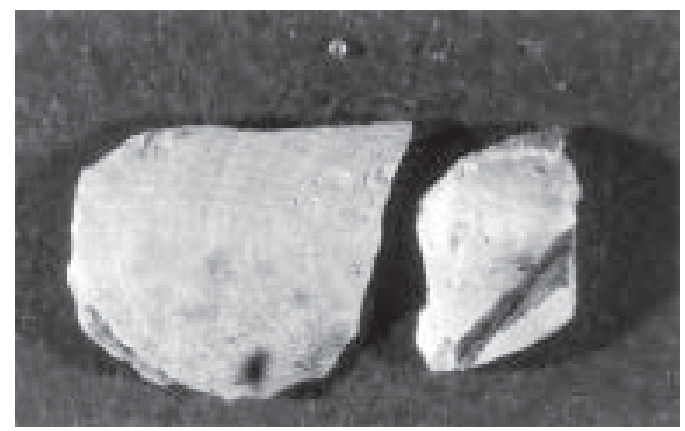

Fig. 55. Bathyarca glacialis (Gray 1824). Skagen 3, 114.64-? m b.s., core sample-57. × 9.6. Fragments of left valve. MGUH 25365. 
Occurrence. The Arctic, Subarctic, Boreal and Lusitanian regions.

Habitat. From $50 \mathrm{~m}$ (the Shetland Isles) to more than $2000 \mathrm{~m}$ (the Mediterranean) (Madsen 1949).

Subfossil finds. None.

\section{Order Mytiloida}

\section{Mytilaster lineatus (Gmelin 1791)}

Distribution. A Mediterranean species according to Jensen \& Spärck (1934) but also found in the neighbouring Atlantic (Poppe \& Goto 1993).

Occurrence. The Lusitanian region.

Habitat. Intertidal, attached to rocks.

Only subfossil finds. The Eemian in the Kattegat and North Sea regions.

\section{Mytilaster solidus form minimus (Poli 1795)}

Distribution. From Bretagne and south into the Mediterranean

Occurrence. The Lusitanian region.

Habitat. Intertidal, attached to rocks or algae.

Subfossil finds. Recorded from the Bælt Sea during the Eemian.

\section{Mytilus edulis Linnaeus 1758}

Fig. 56

Distribution. W and E Greenland, but only along the south-eastern coast (Ockelmann 1958), around Iceland, the Faeroes, Norway north of Lofoten, and south to the Mediterranean. Known from all parts of the Danish waters, including the Baltic.

Occurrence. The Subarctic, Boreal and Lusitanian regions.

Habitat. Intertidal to $40 \mathrm{~m}$ deep, but in Danish waters common as an epifaunal element down to a depth of

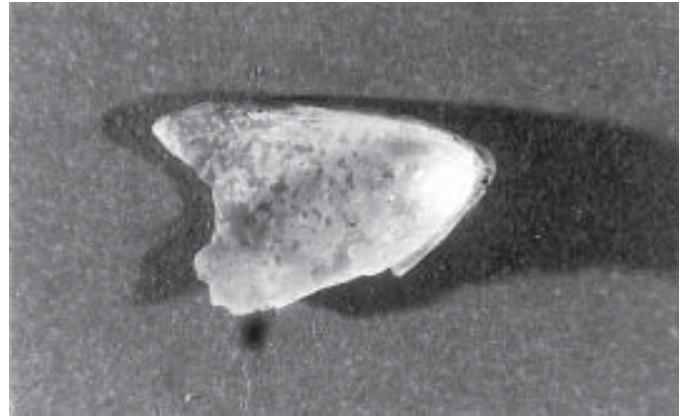

Fig. 56. Mytilus edulis Linnaeus 1758. Skagen 4, 18.7-18.8 m b.s., lab. no. 311,95. × 4.8. Fragment of left valve. MGUH 25366.

$10 \mathrm{~m}$; however, in the Baltic as deep as $40 \mathrm{~m}$ (Jensen \& Spärck 1934).

Subfossil finds. The Bælt Sea, Baltic, Kattegat, Limfjord, North Sea, Vendsyssel and Skagen regions, Holocene. Recorded in the Subatlantic from the Skagen Well. In the Eemian records from the Bælt Sea, Baltic, Kattegat, North Sea and Vendsyssel regions. In the Late Weichselian also recorded from the Vendsyssel region (the Younger Yoldia Sea).

\section{Modiolula phaseolina (Philippi 1844)}

Distribution. From SW and NW Iceland, the Faeroes, Norway north of Lofoten, and south to the British Isles (Petersen 1968) and the Mediterranean. The species extends from the North Sea and Skagerrak into the Kattegat and Øresund (Jensen \& Knudsen 1995), but is not recorded from the Limfjord (Petersen 1986a).

Occurrence. The Boreal and Lusitanian regions.

Habitat. From the tidal zone and down to $160 \mathrm{~m}$, attached by its byssus to rocks or on the base of the larger seaweeds (Poppe \& Goto 1993), but also recorded from depths of $1000 \mathrm{~m}$.

Subfossil finds. The Bælt Sea, Limfjord and Vendsyssel regions, Holocene. Recorded from the Bælt Sea and the North Sea regions during the Eemian.

\section{Modiolus adriaticus (Lamarck 1819)}

Distribution. Recorded from the southern part of the British Isles and Denmark (Petersen 1968) south to the Mediterranean. In Danish waters taken in the Kattegat, including the Øresund (Jensen \& Spärck 1934), but 
not observed in the Limfjord (Petersen 1986a). It might have been passed over in many places, as mentioned by Petersen (1888, p. 127).

Occurrence. The Boreal and Lusitanian regions.

Habitat. Sublittoral between 14 and $75 \mathrm{~m}$ on mud bottoms.

Subfossil finds. The Limfjord and Vendsyssel region, Holocene.

\section{Modiolus modiolus (Linnaeus 1758)}

Distribution. Around Iceland, the Faeroes, Norway north of Lofoten, and south to the British Isles (Petersen 1968) and the Bay of Biscay (Poppe \& Goto 1993). In Danish waters, including the Limfjord, the species extends into the Bælt Sea (Jensen \& Spärck 1934) and the Øresund (Jensen \& Knudsen 1995).

Occurrence. The Subarctic, Boreal and Lusitanian regions.

Habitat. From the extreme low tide down to $150 \mathrm{~m}$ attached with its byssus to rocks or gravel (Poppe \& Goto 1993). In Danish waters the species replaces Mytilus edulis as the dominating epifaunal element in deeper water (Jensen \& Spärck 1934).

Subfossil finds. The Bælt Sea, Limfjord and Vendsyssel regions, Holocene. Recorded from the Baltic and North Sea during the Eemian.

\section{Musculus discors (Linnaeus 1767)}

Fig. 57

Distribution. E and W Greenland, around Iceland and Spitsbergen (Madsen 1949), Norway from north of Lofoten (Petersen 1968) and south to the Mediterranean. In Danish waters the species extends into the Bælt Sea and Øresund (Jensen \& Spärck 1934), but it has not been observed in the Limfjord (Petersen 1986a).

Occurrence. The Arctic, Subarctic, Boreal, and Lusitanian regions.

Habitat. From the intertidal zone on algae (Poppe \& Goto 1993) and rarely on water deeper than about 200 m (Jensen \& Spärck 1934).

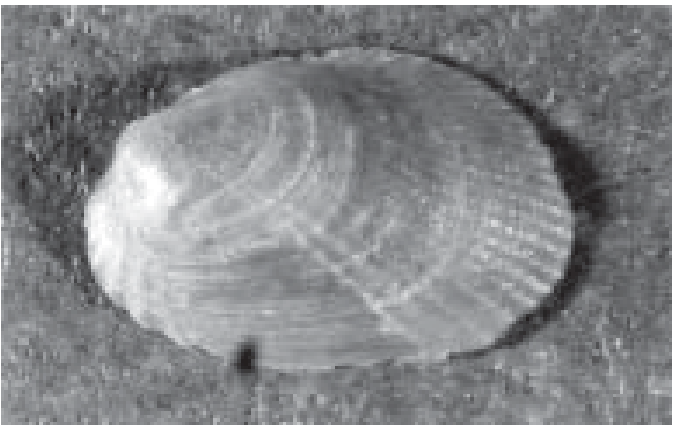

Fig. 57. Musculus discors (Linnaeus 1767). Skagen 4, 28.0-28.5 m b.s., lab. no. 353,93. × 20. Left valve. MGUH 25367.

Subfossil finds. The Bælt Sea, Kattegat, Limfjord, North Sea, Vendsyssel and Skagen regions, Holocene. From the Skagen Well recorded from the Subatlantic.

\section{Musculus laevigatus (Gray 1824)}

Distribution. E and W Greenland, around Iceland and Norway north of Lofoten.

Occurrence. The Arctic, Subarctic and Boreal regions.

Habitat. From the infralittoral zone down to $83 \mathrm{~m}$ (Poppe \& Goto 1993).

Only subfossil finds. Recorded from the Early/Middle Weichselian (the Older Yoldia Sea, but not in the Skærumhede sequence) and the Late Weichselian (the Younger Yoldia Sea) in the Vendsyssel region.

\section{Musculus niger (Gray 1824)}

Distribution. E and W Greenland, around Iceland, the Faeroes, Norway north of Lofoten, and south to the North Sea and the Irish Sea (Madsen 1949; Petersen 1968). In Danish waters the species extends from the North Sea into the Kattegat, Øresund and Brelt Sea as far as Warnemünde (Jensen \& Spärck 1934; Jensen \& Knudsen 1995).

Occurrence. The Arctic, Subarctic and Boreal regions.

Habitat. Most often found in Danish waters at water depths of more than $25 \mathrm{~m}$ (Jensen \& Spärck 1934). Poppe \& Goto (1993) indicate from $7 \mathrm{~m}$ deep down to about $135 \mathrm{~m}$. However, off the East Greenland coast the species is rarely met with at depths exceeding 40 m (Ockelmann 1958). 
Subfossil finds. Recorded from the Vendsyssel region during the Eemian, the Early and Middle Weichselian (the Older Yoldia Sea) and the Late Weichselian (the Younger Yoldia Sea).

\section{Modiolaria tumida (Hanley 1843)}

Distribution. The British Isles and the Shetlands, and south to the Mediterranean (Madsen 1949). In Danish waters the species is very common in the Limfjord, but also in the other fjords, and it extends into the Bælt Sea (Jensen \& Spärck 1934).

Occurrence. The Boreal and Lusitanian regions.

Habitat. It is a common shallow-water species in Danish waters (Jensen \& Spärck 1934), but goes down to $60 \mathrm{~m}$ (Poppe \& Goto 1993) associated with tunicates and echinoderms.

Subfossil finds. The Limfjord and Vendsyssel regions, Holocene. Recorded from the North Sea region during the Eemian.

\section{Crenella decussata (Montagu 1803)}

Distribution. E and W Greenland, around Iceland, Norway north of Lofoten and south to the British Isles (Madsen 1949; Petersen 1968). In Danish waters the species is found in the Kattegat, including the Øresund.

Occurrence. The Arctic, Subarctic and Boreal regions.

Habitat. From 4 to $200 \mathrm{~m}$ deep on all kinds of bottoms (Poppe \& Goto 1993). According to Jensen \& Spärck (1934), most common in Danish waters between 15 and $30 \mathrm{~m}$.

Subfossil finds. Recorded in the Kattegat during the Holocene and from the Early and Middle Weichselian (the Older Yoldia Sea) in the Vendsyssel region.

\section{Adipicola simpsoni (Marshall 1900)}

Distribution. From southern Iceland and south to Portugal and the Mediterranean. Might be found in Danish waters (Jensen \& Spärck 1934).

Occurrence. The Boreal and Lusitanian regions.

Habitat. As mentioned by Poppe \& Goto (1993, p.
48): "The species has been collected repeatedly on the skulls of whales, where it lies, attached in the sutures, by its byssus".

Subfossil finds. None.

\section{Order Pteroida}

\section{Chlamys islandica (O.F. Müller 1776)}

Distribution. SE and W Greenland, around Iceland, Spitsbergen, Norway north of Lofoten, and south to the Shetlands and the Orkney Islands (rare) (Petersen 1968).

Occurrence. The Subarctic and Boreal regions.

Habitat. Around Iceland one of the most common bivalves present from nearly all localities along the NW, N and E coast, both in the fjords and on the outer part of the shelf, at depth from a few metres to $300 \mathrm{~m}$ (Madsen 1949). Common in Danish waters from 10 to $100 \mathrm{~m}$ (Jensen \& Spärck 1934) on rocks and gravel bottoms. Lives attached to hard substrates with its byssus (Poppe \& Goto 1993).

Only subfossil finds. Recorded from the Vendsyssel region during the Early and Middle Weichselian (the Older Yoldia Sea) and the Late Weichselian (the Younger Yoldia Sea).

\section{Aequipecten opercularis (Linnaeus 1758)}

Distribution. Norway from north of Lofoten, and south to the Mediterranean (Petersen 1968). In Danish waters the species extends into the Kattegat and Øresund, but is not recorded from the Limfjord (Petersen 1986a).

Occurrence. The Boreal and Lusitanian regions.

Habitat. From the intertidal zone down to $400 \mathrm{~m}$ on all types of bottoms except rocky ones (Poppe \& Goto 1993).

Subfossil finds. The Limfjord and Vendsyssel regions, Holocene. Recorded from the North Sea region during the Eemian. 


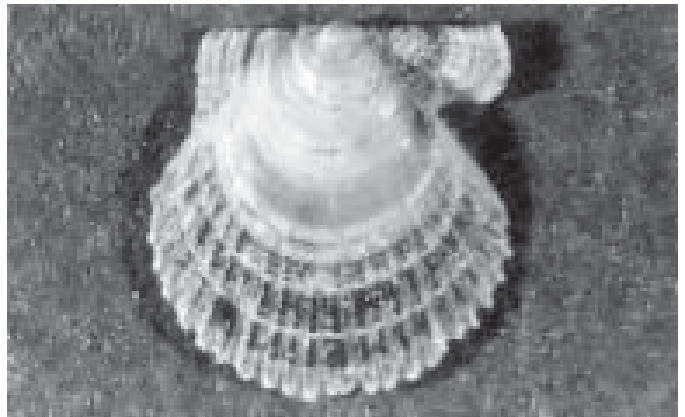

Fig. 58. Chlamys varia (Linnaeus 1758). Skagen 3, 32.85-32.90 m b.s., core sample-2. $\times$ 20. Right valve. MGUH 25368.

\section{Chlamys varia (Linnaeus 1758)}

Fig. 58

Distribution. Norway off the Lofoten islands, and south to the Mediterranean (Petersen 1968). In Danish waters the species occurs in the Limfjord (Jensen \& Spärck 1934) and has been recorded juvenile from the Øresund (Jensen \& Knudsen 1995).

Occurrence. The Boreal and Lusitanian regions.

Habitat. Intertidal to $83 \mathrm{~m}$, attached by its byssus (Poppe \& Goto 1993).

Subfossil finds. The Limfjord, North Sea, Vendsyssel and Skagen regions, Holocene. From the Skagen Well recorded from the Subatlantic. Recorded from the North Sea during the Eemian.

\section{Delectopecten vitreus (Gmelin 1791)}

Fig. 59

Distribution. W Greenland, W Iceland, Spitsbergen, Norway north of Lofoten, and south to the British Isles

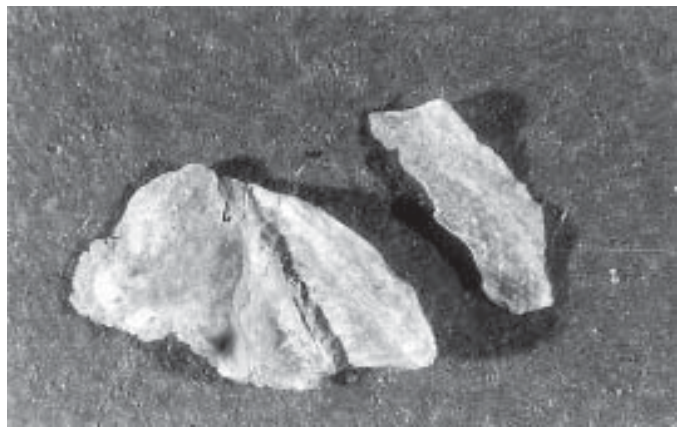

Fig. 59. Delectopecten cf. vitreus (Gmelin 1791). Skagen 3, 183.17-183.40 m b.s., lab. no. 9E+05. × 9.6. MGUH 25369.
(Madsen 1949), and according to Poppe \& Goto (1993) also into the Mediterranean. In Danish waters from the Skagerrak (Jensen \& Spärck 1934).

Occurrence. The Subarctic, Boreal and Lusitanian regions.

Habitat. Between 30 and $600 \mathrm{~m}$, fixed by its byssus to hard substrates (Poppe \& Goto 1993). The species lives in the deeper part of the Skagerrak, from 400 to 600 m, according to Jensen \& Spärck (1934).

Subfossil finds. The Limfjord, Holocene. Recorded from the Eemian in the Skagen Well.

\section{Palliolum greenlandicum (Sowerby 1842)}

Fig. 60

Distribution. E and W Greenland, N and E Iceland, Spitsbergen, and Norway north of Lofoten (Madsen 1949). However, at depths greater than $400 \mathrm{~m}$ the species has been found off the Faeroes and the British Isles.

Occurrence. The Arctic, Subarctic and Boreal regions.

Habitat. In the Arctic seas living in shallow water from $5 \mathrm{~m}$, but most common between 20 and $70 \mathrm{~m}$ on clay bottoms containing stones or shells (Ockelmann 1958).

Only subfossil finds. Recorded from the Vendsyssel region and the Skagen Well during the Early/Middle Weichselian (the Older Yoldia Sea).

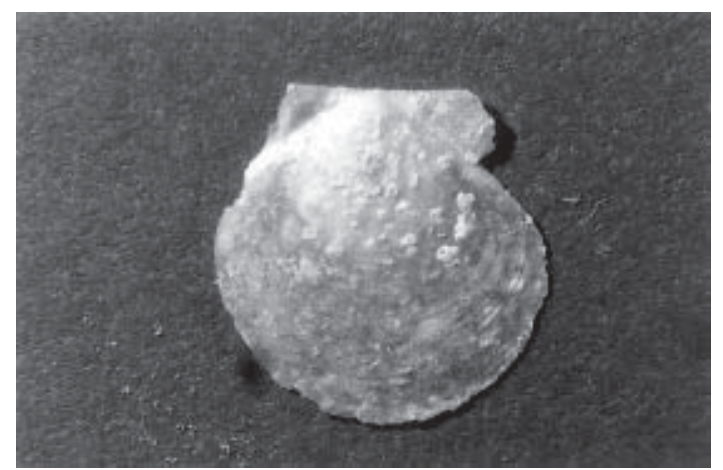

Fig. 60. Palliolum greenlandicum (Sowerby 1842). GEUS collection. East Greenland. × 4.8. Right valve. MGUH 25370 . 


\section{Palliolum striatum (Müller 1776)}

Distribution. From S and W Iceland, the Faeroes, Norway north of Lofoten, and south to the Mediterranean. The species extends from the North Sea and Skagerrak into the Kattegat, including Øresund.

Occurrence. The Boreal and Lusitanian regions.

Habitat. From shallow water around $5 \mathrm{~m}$ to more than $800 \mathrm{~m}$ deep on all types of bottom (Poppe \& Goto 1993). The vertical range off Iceland is indicated to lie between 100 and $260 \mathrm{~m}$ (Madsen 1949).

Subfossil finds. The Limfjord region, Holocene.

\section{Palliolum tigerinum (Müller 1776)}

Distribution. From NW, W and S Iceland, the Faeroes, Norway north of Lofoten, and south to Morocco. In Danish waters from the North Sea and Skagerrak into the Kattegat, including the Øresund.

Occurrence. The Boreal and Lusitanian regions.

Habitat. From the intertidal zone down to $400 \mathrm{~m}$, but deeper in the southern part of its range on sandy bottoms (Poppe \& Goto 1993).

Subfossil finds. The Limfjord region, Holocene.

\section{Pecten maximus (Linnaeus 1758)}

Distribution. Norway off the Lofoten islands and south to Spain. In Danish waters rarely found living in the Kattegat and only shells have been recovered from the Øresund (Jensen \& Knudsen 1995).

Occurrence. The Boreal and Lusitanian regions.

Habitat. From the tidal zone down to $250 \mathrm{~m}$ on sand and gravel bottoms (Poppe \& Goto 1993).

Subfossil finds. Recorded from the Vendsyssel region, Holocene.

\section{Pseudamussium septemradiatum (Müller 1776)}

Distribution. S Iceland, Norway from north of the Lofoten islands, and south to the Mediterranean. In Danish waters the species extends from the Skagerrak and becomes common in the southern Kattegat with finds also in the Øresund (Jensen \& Spärck 1934; Jensen \& Knudsen 1995).

Occurrence. The Boreal and Lusitanian regions.

Habitat. In general living between 60 and $600 \mathrm{~m}$ deep on muddy bottoms (Poppe \& Goto 1993). In Danish waters often found between 30 and $60 \mathrm{~m}$.

Subfossil finds. Recorded from the Vendsyssel region during the Eemian.

\section{Similipecten similis (Laskey 1811)}

Distribution. S and W Iceland, the Faeroes, Norway north of Lofoten, and south to the Mediterranean (Petersen 1968). The species extends into the Kattegat from Skagerrak.

Occurrence. The Boreal and Lusitanian regions.

Habitat. Sublittorally between 4 and $250 \mathrm{~m}$ deep on sand and fine gravel bottoms (Poppe \& Goto 1993). In Danish waters from 30 to $80 \mathrm{~m}$ deep (Jensen \& Spärck 1934). However, the vertical range around Iceland is 200-320 m (Madsen 1949).

Subfossil finds. Recorded from the Vendsyssel area during the Eemian.

\section{Pododesmus patelliformis (Linnaeus 1761)}

Distribution. S and W Iceland, the Faeroes, Norway off the Lofoten islands, and south to the Mediterranean (Madsen 1949). The species extends from the North Sea into the Kattegat, including the Øresund, and occurs also in the Limfjord (Jensen \& Spärck 1934).

Occurrence. The Boreal and Lusitanian regions.

Habitat. Intertidal to $50 \mathrm{~m}$ deep on gravel or rock bottoms, often attached to shells (Poppe \& Goto 1993).

Subfossil finds. The Limfjord and Vendsyssel regions, Holocene.

\section{Pododesmus squama (Gmelin 1791)}

Distribution. Around the British Isles and from Danish waters the occurrences in the Kattegat and Øresund 


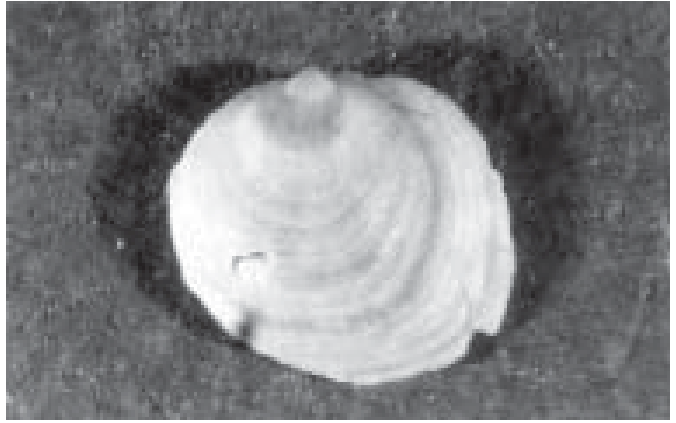

Fig. 61. Heteranomia squamula (Linnaeus 1758). Skagen 4, 21.021.5 m b.s., lab. no. 346,93. × 20. Left valve. MGUH 25371.

are questioned, although larvae occur (Jensen \& Knudsen 1995).

Occurrence. The Boreal and Lusitanian regions.

Habitat. From the tidal zone to $75 \mathrm{~m}$ deep on all types of bottoms attached to hard substrates (Poppe \& Goto 1993).

Subfossil finds. None.

\section{Anomia epbippium Linnaeus 1758}

Distribution. From the British Isles, including the Orkney Islands, and south to the Mediterranean.

Occurrence. Mainly the Lusitanian region.

Habitat. From the intertidal zone down to $150 \mathrm{~m}$ on all kinds of hard substrates.

Only subfossil finds. The Limfjord and the Vendsyssel region, Holocene.

\section{Heteranomia squamula (Linnaeus 1758)}

Fig. 61

Distribution. Around Iceland, the Faeroes, Norway north of Lofoten, and south to the Bay of Biscay. The species extends into the Kattegat, Øresund, and occurs in the Limfjord (Jensen \& Spärck 1934).

Occurrence. The Subarctic, Boreal and Lusitanian regions.

Habitat. From 5 to $110 \mathrm{~m}$ deep fixed on hard substrates, but also on algae and crustaceans (Poppe \& Goto 1993).

Subfossil finds. The Kattegat, Limfjord, North Sea, Vendsyssel and Skagen regions, Holocene. From the Skagen Well recorded from the Subatlantic. During the Eemian recorded from the Brelt Sea and the North Sea regions.

\section{Crassostrea gigas (Gmelin 1791)}

This oyster species from the Portuguese-Spanish region (Poppe \& Goto 1993) has been introduced in 1972 as spat for commercial production (Jensen \& Knudsen 1995) and is not considered here, although mentioned as now part of the Danish molluscan fauna. No subfossil records either.

\section{Ostrea edulis Linnaeus 1758}

Fig. 62a, b

Distribution. From the southern part of the west coast of Norway south to the Mediterranean. In Danish waters only common in the western part of the Limfjord, although stray specimens are found in the northern North Sea, Skagerrak and northern Kattegat (Jensen \& Spärck 1934; Jensen \& Knudsen 1995).
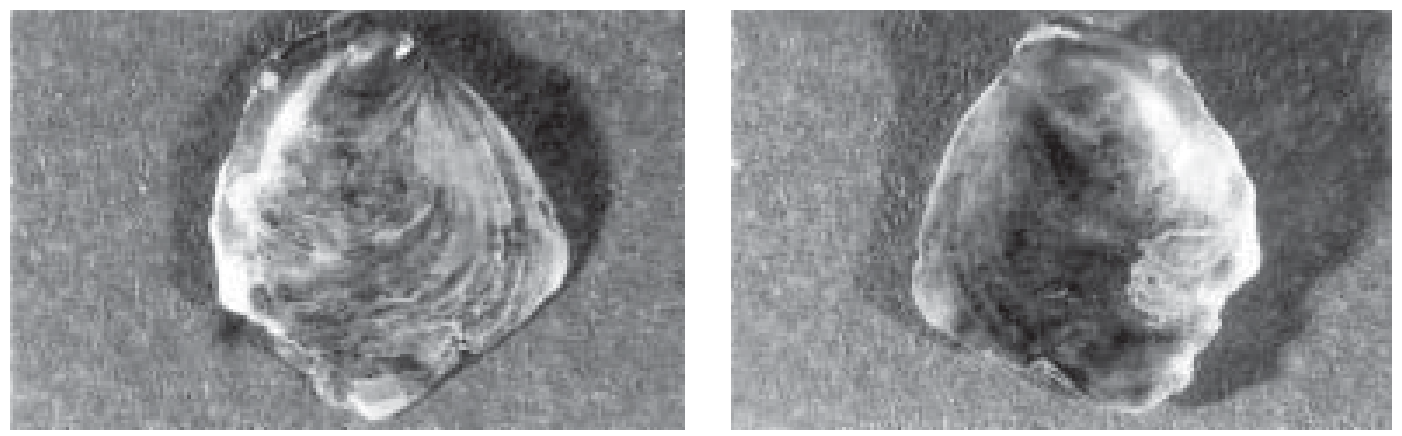

Fig. 62. a, b: Ostrea edulis Linnaeus 1758. Skagen 4, 8.0-8.5 m b.s., lab. no. 333,93. × 9.6. Left valve of juvenile specimen (exterior and interior, respectively). MGUH 25372. 
Occurrence. The Boreal and Lusitanian regions.

Habitat. From the tidal zone down to $90 \mathrm{~m}$ on all types of bottoms. In Danish waters the species can be found at depths of 3 to $7 \mathrm{~m}$ in the Limfjord, but also deeper elsewhere (Jensen \& Spärck 1934).

Subfossil finds. The Bælt Sea, Kattegat, Limfjord, North Sea, Vendsyssel and Skagen regions, Holocene. Recorded from the Subatlantic in the Skagen Well. Finds from the Bxlt Sea, Kattegat, and North Sea regions during the Eemian.

\section{Limaria bians (Gmelin 1791)}

Distribution. Norway north of Lofoten, the Orkney islands and south to the Mediterranean (Petersen 1968). A few records from the northern and central parts of the Kattegat (Jensen \& Knudsen 1995). Already Jensen \& Spärck (1934) mentioned that the species then known from the deeper parts of the North Sea might occur in Danish waters.

Occurrence. The Boreal and Lusitanian regions.

Habitat. Lives from the low tide mark zone down to $100 \mathrm{~m}$ on coarse sand and gravel bottoms (Poppe \& Goto 1993).

Subfossil finds. None.

\section{Limaria loscombi (Sowerby 1832)}

Distribution. Norway off the Lofoten islands, the Faeroes and south to the Mediterranean (Petersen 1968). Poppe \& Goto (1993) mentioned occurrences of $L$. bians and L. loscombi off Iceland which, however, cannot be found in the other literature. In Danish waters the species has been found in the Kattegat, including the Øresund (Jensen \& Knudsen 1995).

Occurrence. The Boreal and Lusitanian regions.

Habitat. Lives from 35 to $100 \mathrm{~m}$ deep on fine sand and sand-mud bottoms (Poppe \& Goto 1993). In Danish waters it is characteristic in the south-eastern part of Kattegat together with Pseudamussium septemradiatum (Jensen \& Spärck 1934).

Subfossil finds. None.

\section{Limatula subauriculata (Montagu 1808)}

Distribution. SE and W Greenland, N and E Iceland, Norway north of Lofoten, and south to the Mediterranean (Petersen 1968). In the Danish waters only shells have been recorded from the northern Kattegat (Jensen \& Knudsen 1995).

Occurrence. The Subarctic, Boreal and Lusitanian regions.

Habitat. Especially living on the continental shelves. However, records ranges from 4 to $2000 \mathrm{~m}$ (Poppe \& Goto 1993).

Subfossil finds. None.

\section{Subclass Heterodonta Order Veneroida}

\section{Chama gryphoides Linnaeus 1767}

This Lusitanian species (up to the coasts of Portugal) has only one record from Danish waters (Jensen \& Knudsen 1995), and this is considered to have been dropped by a ship. Therefore it will not be discussed. No subfossil records.

\section{Lucinella divaricata (Linnaeus 1758)}

Distribution. From the English Channel and southern part of the North Sea south to the Mediterranean.

Occurrence. Mainly the Lusitanian region.

Habitat. From the tidal zone down to a depth of $60 \mathrm{~m}$ in fine sand and/or mud (Poppe \& Goto 1993).

Only subfossil finds. The Eemian in the Bælt Sea, Kattegat, and North Sea regions.

\section{Lucinoma borealis (Linnaeus 1758)}

Distribution. The Faeroe islands, Norway from off Lofoten, and south to the Mediterranean (Petersen 1968). In Danish waters the species occurs in the Kattegat, including the Øresund, but is not recorded from the Limfjord (Petersen 1986a).

Occurrence. The Boreal and Lusitanian regions. 
Habitat. From the intertidal zone down to $500 \mathrm{~m}$ deep on gravel bottoms and in pure sand and/or mud (Poppe \& Goto 1993). In Danish waters between 20 and $50 \mathrm{~m}$ (Jensen \& Spärck 1934).

Subfossil finds. The Limfjord and Vendsyssel regions, Holocene.

\section{Myrtea spinifera (Montagu 1803)}

Distribution. From Norway south to Morocco. In Danish waters recorded from the northern Kattegat (Jensen \& Knudsen 1995).

Occurrence. The Boreal and Lusitanian regions.

Habitat. From 7 to $250 \mathrm{~m}$ deep on sand, mud and gravel bottoms (Poppe \& Goto 1993).

Subfossil finds. None.

\section{Axinopsida orbiculata (G.O. Sars 1878)}

Distribution. E and W Greenland, around Iceland, the Faeroes, and Norway north and just south of the Lofoten Islands (Petersen 1968). The species occurs off the north western part of Scotland.

Occurrence. The Arctic, Subarctic and Boreal regions.

Habitat. From 2 to $50 \mathrm{~m}$ deep on sand, clay and mud around Iceland (Madsen 1949). North of the Hebrides occurring at depths down to $900 \mathrm{~m}$ (Jensen \& Spärck 1934).

Only subfossil finds. The Vendsyssel region from the Early and Middle Weichselian (the Older Yoldia Sea) and the Late Weichselian (the Younger Yoldia Sea).

\section{Thyasira croulinensis (Jeffreys 1847)}

Distribution. W Greenland, around Iceland, the Faeroes, Norway north of Lofoten (Petersen 1968), and south to the Mediterranean (Poppe \& Goto 1993). In Danish waters taken in the North Sea and Skagerrak.

Occurrence. The Subarctic, Boreal and Lusitanian regions.

Habitat. About 40 to 2500 m off the Faeroes on gravel and clay (Petersen 1968). In Danish waters the species is found in the deeper water (Jensen \& Spärck 1934).

Subfossil finds. None.

\section{Thyasira equalis (Verrill \& Bush 1898)}

Distribution. It is questioned by Nordsieck (1969, p. 79) if T. equalis should be Thyasira flexuosa var. rotunda. There are no subfossil finds under the name of T. equalis, so this species will not be considered any further. However, as discussed by Ockelmann (1958, p. 100) a species, T. equalis, does occur in the Arctic, while T. flexuosa has a Boreo-Lusitanian main distribution.

\section{Thyasira flexuosa (Montagu 1803)}

Fig. 63

Distribution. E and W Greenland, Spitsbergen, around Iceland, the Faeroes, Norway north of Lofoten, and south to the Mediterranean. In the Danish waters it is very common and extends into the Øresund (Jensen \& Knudsen 1995), but is not recorded from the Limfjord (Petersen 1986a).

Occurrence. The Arctic, Subarctic, Boreal and Lusitanian regions (see comments under T. equalis).

Habitat. From 10 to $2000 \mathrm{~m}$ deep on sand and mud bottoms (Poppe \& Goto 1993). In Danish waters from $20 \mathrm{~m}$ to around $100 \mathrm{~m}$ deep on clay bottoms (Jensen \& Spärck 1934). From the North Sea recorded at 30 to $200 \mathrm{~m}$ depths on mixed bottom in the trenches around the Dogger Bank (Petersen 1977).

Subfossil finds. The Limfjord, North Sea, Vendsyssel

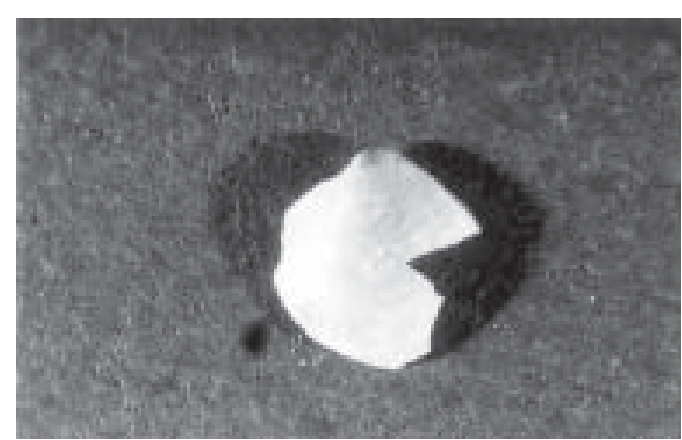

Fig. 63. Thyasira flexuosa (Montagu 1803). Skagen 3, 35.9036.00 m b.s., lab. no. 496,93. × 9.6. Left valve. MGUH 25373. 
and Skagen regions, Holocene. From the Skagen Well recorded from the Subatlantic. From the North Sea during the Eemian and in the Vendsyssel region recorded from the Late Weichselian (the Younger Yoldia Sea).

\section{Thyasira sarsi (Philippi 1845)}

Distribution. From Novaja Semlja along the coast of Norway south to the Skagerrak region. The species extends into the Kattegat, including the Øresund (Jensen \& Knudsen 1995).

Occurrence. The Arctic, Subarctic and Boreal regions.

Habitat. From 100 m to deep water.

Subfossil finds. None.

\section{Leptaxinus ferruginosus (Forbes 1844)}

Distribution. W Greenland, W Iceland, Spitsbergen, Norway off the Lofoten islands, and southwards to Madeira (Madsen 1949). Jensen \& Spärck (1934) mentioned the species from the deeper part of the Skagerrak, but Jensen \& Knudsen (1995) have no further record of this species as belonging to the recent Danish fauna.

Occurrence. The Arctic, Subarctic, Boreal and Lusitanian regions.

Habitat. About $20 \mathrm{~m}$ to more than $3000 \mathrm{~m}$. The vertical range off Iceland is $320-560 \mathrm{~m}$. So here is another example of tropical submerge (see Order Mesogastropoda Natica affinis).

Subfossil finds. Recorded from the Vendsyssel region during the Eemian.

\section{Mysella bidentata (Montagu 1803)}

Fig. 64

Distribution. Around Iceland, the Faeroes, Norway from north of Lofoten, and south to West Africa (Petersen 1968). The species has a common distribution in Danish waters, including the Limfjord, south to the Bælt Sea by Warnemünde (Arntz et al. 1976), and the Øresund (Jensen \& Spärck 1934). Also found in the North Sea (Petersen 1977).

Occurrence. The Subarctic, Boreal and Lusitanian regions.

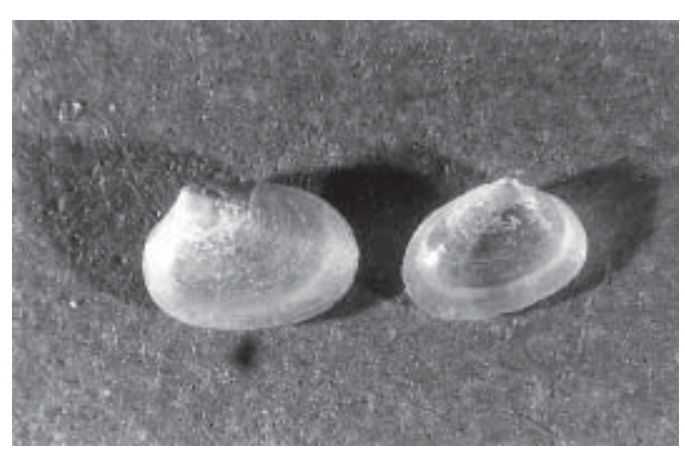

Fig. 64. Mysella bidentata (Montagu 1803). Skagen 4, 27.0-27.5 m b.s., lab. no. $352,93 . \times 9.6$. To the left a specimen seen from the right, and to the right a left valve. MGUH 25374.

Habitat. Intertidal zone down to $2500 \mathrm{~m}$, often in commensal association with other animals. In the North Sea it is recorded from 20 to $90 \mathrm{~m}$ as a commensal on for example, Acrocnida brachiata (Petersen 1977).

Subfossil finds. The Bælt Sea, Kattegat, Limfjord, North Sea, Vendsyssel and Skagen regions, Holocene. From the Skagen Well, records from the Preboreal-Boreal, Subboreal and Subatlantic. From the Bælt Sea, Baltic, North Sea and Vendsyssel regions also recorded from the Eemian.

\section{Mysella tumidula (Jeffreys 1867)}

Distribution. This species is recorded by Jensen \& Knudsen (1995) as being part of the Danish fauna, although it seems to have a purely Lusitanian distribution (Poppe \& Goto 1993). The species has no subfossil occurrence.

\section{Montacuta substriata (Montagu 1803)}

Distribution. W Iceland, the Faeroes, Norway north of Lofoten, and south to the Mediterranean. In Danish waters rarely found in the North Sea, Skagerrak and Kattegat.

Occurrence. The Boreal and Lusitanian regions.

Habitat. Off Iceland the vertical range is between 31 and $165 \mathrm{~m}$ (Madsen 1949). In Danish waters out to depths of around $700 \mathrm{~m}$ (Skagerrak) reported as a commensal on Spatangus purpureus (Jensen \& Spärck 1934) and from the North Sea also on Echinocardium flavesens at depths from 30 to $100 \mathrm{~m}$ (Petersen 1977).

Subfossil finds. None. 


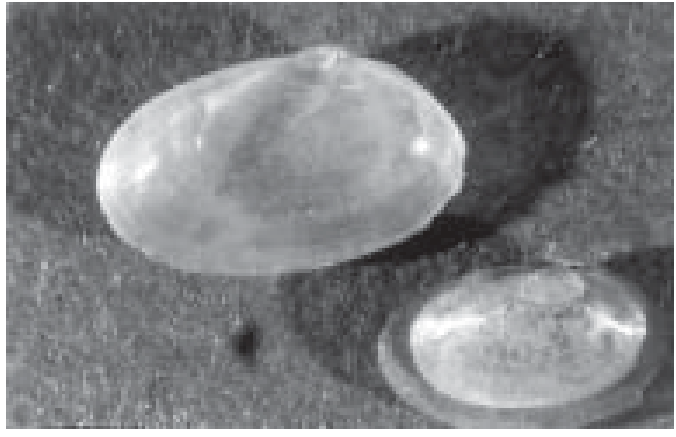

Fig. 65. Tellimya ferruginosa (Montagu 1803). Skagen 4, 27.0$27.5 \mathrm{~m}$ b.s., lab. no. $352,93 . \times 9.6$. To the left interior of a right valve, and to the right a specimen seen from the left. MGUH 25375.

\section{Tellimya ferruginosa (Montagu 1803)}

Fig. 65

Distribution. Around Iceland, the Faeroes, Norway north of Lofoten, and south to the Mediterranean. In Danish waters the species extends from the North Sea, Limfjord, and Skagerrak into the Kattegat and Øresund (Jensen \& Spärck 1934).

Occurrence. The Subarctic, Boreal and Lusitanian regions.

Habitat. In general the species is most common just below the tidal zone, which according to Poppe \& Goto (1993) is the preferred habitat of Echinocardium with which T. ferruginosa is often associated. However, the species is also found on Brissopsis lyrifera or living by itself (Jensen \& Spärck 1934). Accordingly, the depth range may vary, around Iceland being between 32 and $80 \mathrm{~m}$ (Madsen 1949).

Subfossil finds. The Limfjord, North Sea, Vendsyssel and Skagen regions, Holocene. The records from the Skagen Well are from the Subboreal and Subatlantic. Furthermore, the species has been recorded from the Bælt Sea and North Sea during the Eemian.

\section{Mysella dawsoni (Jeffreys 1864)}

Distribution. Petersen (1888, p. 154) mentioned a single find from the Limfjord, and the species is mentioned by Petersen (1986a) on the basis of the tables on molluscan finds in the Limfjord from Danmarks Fiskeri- og Havundersøgelser (Petersen 1976). However, it is not cited among the recent Danish species by Jensen \& Knudsen (1995). The species is mentioned from W Greenland (Thorson 1951) and south to the Mediterranean (Poppe \& Goto 1993), and also from Spitsbergen and the west coast of Norway (Jensen \& Spärck 1934).

Occurrence. The Arctic, Subarctic, Boreal and Lusitanian regions.

Habitat. Deep-living species, but mentioned from a depth of $5 \mathrm{~m}$ by Posselt \& Jensen (1898) and in sandy bottom in West Greenland.

Subfossil finds. None.

\section{Tellimya tenella (Lovén 1846)}

Cited only from the Kattegat, including the Øresund, by Jensen \& Knudsen (1995). No subfossil finds. Will not be considered further.

\section{Turtonia minuta (Fabricius 1780)}

Fig. 66

Distribution. W Greenland, around Iceland, the Faeroes, Norway north of Lofoten, and south to the Mediterranean.

Occurrence. The Subarctic, Boreal and Lusitanian regions.

Habitat. Lives in the tidal zone among plants and algae on rocks (Poppe \& Goto 1993). Off Iceland in the tidal zone all around the island, but also down to a depth of $50 \mathrm{~m}$ (Petersen 1968).

Only subfossil finds. The Limfjord, Vendsyssel and

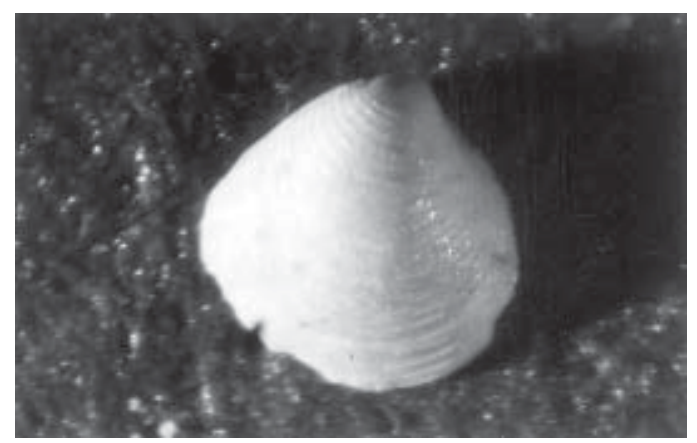

Fig. 66. Turtonia minuta (Fabricius 1780). Skagen 3, 39.8540.02 m b.s., lab. no. 711,93. × 40. Right valve. MGUH 25376. 
Skagen regions, Holocene. Recorded from the Subatlantic in the Skagen Well.

\section{Lepton nitidum (Turton 1822)}

Distribution. From the Faeroes, western Norway, and south to the Mediterranean (Jensen \& Spärck 1934; Madsen 1949). Only recently recorded from the northern Kattegat and Øresund (Jensen \& Knudsen 1995).

Occurrence. The Boreal and Lusitanian regions.

Habitat. From 18 to 216 m, commensal on the crustaceans Upogebia deltaura and Gebia stellata (Nordsieck 1969, p. 89).

Subfossil finds. The Limfjord, North Sea and Vendsyssel regions, Holocene. Recorded from the Eemian in the Bælt Sea and North Sea areas.

\section{Lepton squamosum (Montagu 1803)}

Distribution. From the west coast of Norway and south to Spain. Only shells have been found in Danish waters (northern Kattegat) mentioned by Jensen \& Knudsen (1995).

Occurrence. The Boreal and Lusitanian regions.

Habitat. From 10 to $120 \mathrm{~m}$ deep it lives in and around the burrows of the crustaceans (Upogebia deltaura and U. stellata) on mud or gravel bottoms (Poppe \& Goto 1993).

Subfossil finds. None.

\section{Devonia perrieri (Malard 1904)}

Distribution. From the British Isles south to Spain. In Danish waters recorded from the northern Kattegat (Jensen \& Knudsen 1995).

Occurrence. The Boreal and Lusitanian regions.

Habitat. This species is a commensal on Leptosynapta inhaerens (Nordsieck 1969, p. 95).

Subfossil finds. None.

\section{Kellia suborbicularis (Montagu 1803)}

Distribution. S and W Iceland, the Faeroes, Norway off the Lofoten islands and south to the Mediterranean. In Danish waters recorded from the northern Kattegat and Øresund (Jensen \& Knudsen 1995).

Occurrence. The Boreal and Lusitanian regions.

Habitat. Intertidal to $120 \mathrm{~m}$ deep in crevices, shells or in borings made by other species (Poppe \& Goto 1993).

Subfossil finds. Recorded from the Vendsyssel region, Holocene.

\section{Potidoma dorkiae (Clark 1852)}

This species has been recorded only in a single find by Jensen \& Knudsen (1995), and there are no subfossil finds from the literature, so it will not be considered further.

\section{Astarte sulcata (da Costa 1778)}

Distribution. SE and W Greenland, S and W Iceland, the Faeroes, Norway north of Lofoten, and south to the Mediterranean. The species extends from the North Sea into the Kattegat, but is not common (Jensen \& Spärck 1934).

Occurrence. The Subarctic, Boreal and Lusitanian regions.

Habitat. Sublittorally from $20 \mathrm{~m}$ and deeper on sand, mud and gravel bottoms.

Subfossil finds. None.

\section{Tridonta borealis Schumacher 1817}

Distribution. This species is found in all regions of the north Atlantic except the British Isles (Madsen 1949). However, according to Petersen (1968) the species has not been recorded from the Faeroes. In the Danish waters the species extends from the deeper part of the northern North Sea (single finds) into the Kattegat, including the Øresund and the Bælt Sea, becoming very common in the Baltic (Jensen \& Spärck 1934).

Occurrence. The Arctic, Subarctic and Boreal regions. 
Habitat. From below the tidal zone down to $250 \mathrm{~m}$ on mud, sand and gravel bottoms. The species is "a common member of all the zones of the Arctic Macoma community, and the Gomphina fluctuosa community" (Ockelmann 1958, p. 83).

Subfossil finds. The Bælt Sea and Limfjord regions, Holocene. Recorded from the Vendsyssel region both in the Early/Middle Weichselian (not in the Skærumhede sequence) and the Late Weichselian (the Older Yoldia Sea and the Younger Yoldia Sea respectively).

\section{Tridonta elliptica (Brown 1827)}

Distribution. This species is found in all regions of the north Atlantic, including the British Isles (Madsen 1949). Petersen (1968) specified the occurrence of this species to be in the Clyde Sea and off the Isle of Man only. In the Danish waters it occurs in the Kattegat, Øresund, the Bælt Sea and the Baltic, where it becomes as common as T. borealis (Jensen \& Spärck 1934).

Occurrence. The Arctic, Subarctic and Boreal regions. Considering the occurrences on the west coast of Britain it is also in the northern part of the Lusitanian region, but here probably mostly in deeper water.

Habitat. The vertical range for this species is off Iceland 6 to $300 \mathrm{~m}$ (Madsen 1949), and off the East Greenland coast it is most often taken between about 5 and $50 \mathrm{~m}$, being abundant locally within the Arctic $\mathrm{Ma}$ coma community (Ockelmann 1958).

Subfossil finds. Recorded from the North Sea during the Eemian, and in Vendsyssel during the Early/Middle Weichselian, being part of the Older Yoldia Sea found in the Skærumhede sequence (Jessen et al. 1910).

\section{Tridonta montagui (Dillwyn 1817)}

Distribution. E and W Greenland, around Iceland, Spitsbergen, the Faeroes, Norway form north of Lofoten, and south to the Clyde Sea and Isle of Man (Petersen 1968), also recorded from the Bay of Biscay. It is present in the north western part of the North Sea (Petersen 1977) and common in the Kattegat, Øresund and extending into the Bælt Sea (Jensen \& Spärck 1934).

Occurrence. The Arctic, Subarctic, Boreal and Lusitanian regions.
Habitat. The vertical range off Iceland is $7-150 \mathrm{~m}$ (Madsen 1949) and in the North Sea sampled at depths between 40 and $75 \mathrm{~m}$ on mixed bottom in the trenches around the Dogger Bank (Petersen 1977, p. 226).

Subfossil finds. Recorded from the North Sea region during the Eemian and from the Vendsyssel area during the Early/Middle Weichselian (the Older Yoldia Sea).

\section{Acantbocardia echinata (Linnaeus 1758)}

Fig. 67

Distribution. S and W Iceland, Norway north of Lofoten, and south to the Mediterranean (Madsen 1949). In Danish waters the species extends from the North Sea (Petersen 1977) into the Skagerrak, Limfjord, and Kattegat regions and the Øresund (Jensen \& Spärck 1934).

Occurrence. The Boreal and Lusitanian regions.

Habitat. From 4 to $350 \mathrm{~m}$ deep on mud, sand and gravel bottoms (Poppe \& Goto 1993).

Subfossil finds. The Kattegat, Limfjord, North Sea, Vendsyssel and Skagen regions, Holocene. From the Skagen Well recorded from the Subboreal and Subatlantic. There are Eemian records from the Bælt Sea, Kattegat, North Sea and Vendsyssel regions.

\section{Parvicardium exiguum (Gmelin 1791)}

Distribution. Norway north of Lofoten and south to the Mediterranean (Madsen 1949). In Danish waters common in bays and fjords, including the Limfjord. Considering all the variations belonging to the same species it extends into the Bælt Sea (Petersen 1888).

Occurrence. The Boreal and Lusitanian regions.

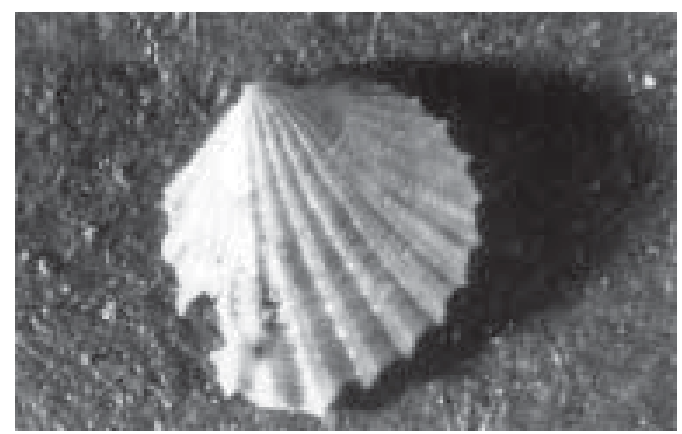

Fig. 67. Acanthocardia echinata (Linnaeus 1758). Skagen 4 , 27.0-27.5 m b.s., lab. no. 352,93. × 20. Right valve. MGUH 25377. 
Habitat. In general occurring from low tide to about 55 m deep (Poppe \& Goto 1993); however, according to Rasmussen (1973) the species has its main occurrence along the shores and is associated with vegetation.

Subfossil finds. The Bælt Sea, Baltic, Kattegat, Limfjord, North Sea and Vendsyssel regions, Holocene. Recorded also from the Bælt Sea, Kattegat, and North Sea regions during the Eemian.

\section{Parvicardium bauniense (Petersen \& Russell 1971)}

Distribution. This newly established species has been recorded from recent Danish waters, but no subfossil records are at hand.

\section{Parvicardium ovale (Sowerby 1840)}

Distribution. Around Iceland, Norway north of Lofoten, and south to the Mediterranean (Madsen 1949). In Danish waters the species is found in all the regions except the Baltic extending only to Darss (Jensen \& Spärck 1934).

Occurrence. The Subarctic, Boreal and Lusitanian regions.

Habitat. According to the Icelandic records (Madsen 1949) found between 5 to $350 \mathrm{~m}$ on bottoms such as mud, sand, clay and shell gravel with stones.

Subfossil finds. The Bælt Sea, Limfjord, North Sea and Vendsyssel regions, Holocene. From the North Sea and Vendsyssel regions also recorded from the Eemian.

\section{Parvicardium scabrum (Philippi 1844)}

Distribution. From Norway north of the Lofoten islands, and south to the Mediterranean (Madsen 1949). In Danish waters common in the Limfjord (Jensen \& Spärck 1934) and recorded from the Kattegat, but questioned, as there may be two separate species (Jensen \& Knudsen 1995).

Occurrence. The Boreal and Lusitanian regions.

Habitat. From the intertidal zone to several hundred metres deep on sand, mud and gravel bottoms (Poppe \& Goto 1993).
Subfossil finds. The Bælt Sea, Kattegat, Limfjord, North Sea and Vendsyssel regions, Holocene. Recorded from the North Sea during the Eemian.

\section{Plagiocardium papillosum (Poli 1795)}

Distribution. From the English Channel south into the Mediterranean (Poppe \& Goto 1993).

Occurrence. The Lusitanian region.

Habitat. From 1 to $60 \mathrm{~m}$ deep on rough sand and gravel bottoms.

Only subfossil finds. Recorded from the Eemian in the North Sea region.

\section{Parvicardium minimum (Philippi 1836)}

Fig. 68

Distribution. S and W Iceland, the Faeroes, Norway north of Lofoten, and south to the Mediterranean at greater depths. In Danish waters common in the deeper part of the Skagerrak extending into the Kattegat, including the Øresund (Petersen 1888). The occurrence in the Limfjord is questioned (Petersen 1986a).

Occurrence. The Boreal and Lusitanian regions.

Habitat. From 4 to $161 \mathrm{~m}$ on mud, sand and gravel bottoms (Poppe \& Goto 1993). However, according to Madsen (1949) the species has around Iceland only been found at depths of more than $75 \mathrm{~m}$, and the bottoms are recorded as sand with shells and stones or as ooze and clay. In Danish waters the species prefers

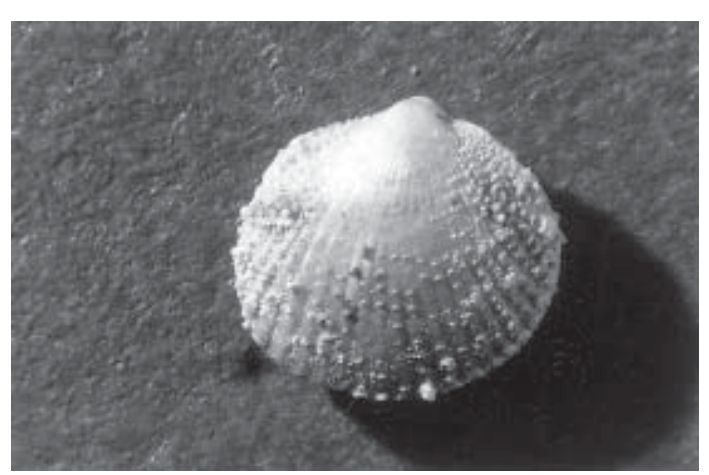

Fig. 68. Parvicardium minimum (Philippi 1836). GEUS collection. North of Skagen, Denmark. $\times 9$.6. Specimen seen from the right. MGUH 25378. 
depths of more than about $30 \mathrm{~m}$, and it occurs at the greatest depth (Petersen 1888).

Subfossil finds. The North Sea and Skagen regions, Holocene. Recorded from the Skagen Well during the Preboreal-Boreal, the Atlantic, Subboreal and Subatlantic. From the Vendsyssel region recorded from the Eemian.

\section{Cerastoderma edule (Linnaeus 1758)}

Distribution. Norway north of the Lofoten islands, and south to the Mediterranean (Madsen 1949). In Danish waters found in all regions (Petersen 1888, p. 136 who already stressed that it is a very variable species).

Occurrence. The Boreal and Lusitanian regions.

Habitat. This is a shallow-water infaunal species - intertidal to few metres deep, but in the Baltic occurring also at 20-30 m depths (Jensen \& Spärck 1934) on sandy bottoms.

Subfossil finds. The Bælt Sea, Baltic, Kattegat, Limfjord, North Sea and Vendsyssel regions, Holocene. From the Eemian recorded in the Brelt Sea, Baltic, Kattegat and North Sea regions.

\section{Cerastoderma glaucum (Poiret 1789)}

Distribution. From the west coast of Norway south to the Mediterranean (Poppe \& Goto 1993, pp. 95-96). In Danish waters the species extends into the Baltic (Jensen \& Spärck 1934).

Occurrence. The Boreal and Lusitanian regions.

Habitat. This is a shallow-water species on sand and mud bottoms. However, according to studies on subfossil material (Rasmussen 1973, p. 298-302), the associated fauna indicates a tidal estuarine environment for the Danish material of an Ertebølle age in the Isefjord.

Subfossil finds. The Baltic, Kattegat and Limfjord regions, Holocene. However, the species identifications on the subfossil material recorded through time should be taken with some reservation on the basis of the great difficulties connected with recent species identifications.

\section{Clinocardium ciliatum (Fabricius 1780)}

Distribution. W and E Greenland, Spitsbergen, around Iceland and Norway north of the Lofoten islands. From the Faeroes only at depths exceeding $400 \mathrm{~m}$ (Petersen 1968).

Occurrence. The Arctic, Subarctic and Boreal (HighBoreal) regions.

Habitat. From the tidal zone down to 700 m, off Iceland occurring on ooze, mud, clay, sand and mixed bottoms (Madsen 1949). Mainly found in the Arctic Macoma community (Ockelmann 1958).

Only subfossil finds. From the Vendsyssel region recorded both from the Eemian and from the Early/Middle Weichselian (the Older Yoldia Sea).

\section{Laevicardium crassum (Gmelin 1791)}

Distribution. From Norway north of the Lofoten islands and south to the Mediterranean. In Danish waters only recorded from the North Sea (Petersen 1977) and the northern part of the Kattegat (Jensen \& Spärck 1934).

Occurrence. The Boreal and Lusitanian regions.

Habitat. From the tidal zone down to $183 \mathrm{~m}$ deep on sand, mud or gravel bottoms.

Subfossil finds. The Vendsyssel region, Holocene. From the Eemian recorded in the Kattegat region.

\section{Serripes groenlandicus (Bruguière 1798)}

Distribution. W and E Greenland, Spitsbergen, around Iceland and Norway north of Lofoten. From the Faeroes only at depths exceeding $400 \mathrm{~m}$ (Petersen 1968).

Occurrence. The Arctic, Subarctic and Boreal (HighBoreal) regions.

Habitat. From 0 to $1 \mathrm{~m}$ to $120 \mathrm{~m}$ deep on clay and mud, but also sand and gravel are recorded (Madsen 1949).

Subfossil finds. From the Vendsyssel area during the Eemian and Early/Middle Weichselian. 


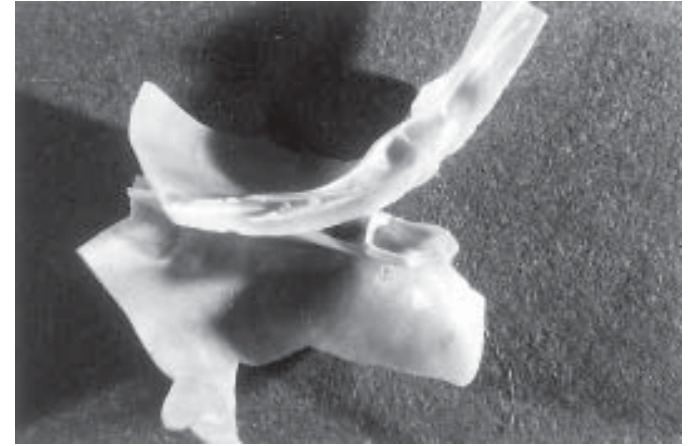

Fig. 69. Mactra stultorum (Linnaeus 1758). Skagen 4, 15.0-15.5 m b.s., lab. no. 340,93. $\times$ 4.8. Hinges of two right valves. MGUH 25379 .

\section{Mactra stultorum (Linnaeus 1758)}

Fig. 69

Distribution. From the British Isles and Denmark south to the Mediterranean (Petersen 1968). In the Danish waters the species is common in the North Sea and Skagerrak, extending into the Limfjord (Petersen 1986a), Kattegat and Øresund, although here only juveniles are present (Jensen \& Knudsen 1995).

Occurrence. The Boreal and Lusitanian regions.

Habitat. From the tidal zone down to $60 \mathrm{~m}$ in clean sand.

Subfossil finds. The Limfjord, North Sea, Vendsyssel and Skagen regions, Holocene. From the Skagen Well recorded from the Subatlantic. During the Eemian recorded from the Brlt Sea region.

\section{Lutraria lutraria (Linnaeus 1758)}

Distribution. Norway off the Lofoten islands and south to the Mediterranean. Since 1990 live specimens have been taken in Danish waters near Frederikshavn and at the Skagerrak coast (Jensen \& Knudsen 1995).

Occurrence. The Boreal and Lusitanian regions.

Habitat. Intertidal down to $100 \mathrm{~m}$, lives at depths up to $35 \mathrm{~cm}$, burrowing in sand, sand-mud or gravel bottoms (Poppe \& Goto 1993).

Subfossil finds. The Limfjord and Vendsyssel regions, Holocene.

\section{Spisula elliptica (Brown 1827)}

Distribution. Around Iceland, the Faeroes, Norway north of Lofoten, and south to the English Channel and Gibraltar. The species occurs in the North Sea, extending into the Limfjord and Kattegat and the Øresund (Jensen \& Knudsen 1995).

Occurrence. The Subarctic, Boreal and Lusitanian regions.

Habitat. Between 20 and $200 \mathrm{~m}$ deep in mud, sand and gravel bottoms.

Subfossil finds. The Limfjord, North Sea and Vendsyssel regions, Holocene. From the Bælt Sea region recorded during the Eemian.

\section{Spisula solida (Linnaeus 1758)}

Distribution. S and W Iceland, and south to the Mediterranean (Petersen 1968). In Danish waters very common offshore from the west coast of Jylland (Jensen \& Knudsen 1995 - as recorded by Petersen 1977, fig. 25). The species extends into the Limfjord (Petersen 1986a) and Kattegat, including the Øresund and the Bælt Sea regions (Jensen \& Spärck 1934).

Occurrence. The Boreal and Lusitanian regions.

Habitat. From the intertidal zone down to $100 \mathrm{~m}$ on sandy bottoms. In the North Sea found at 15-40 m depths in coarse sand (Petersen 1977).

Subfossil finds. The Limfjord, North Sea and Vendsyssel regions, Holocene. Recorded from the Kattegat during the Eemian.

\section{Spisula subtruncata (da Costa 1778)}

Fig. 70a, b

Distribution. Norway north of the Lofoten islands, and south to the Mediterranean (Petersen 1968). In Danish waters the species extends from the North Sea into the Kattegat, where it is also common. The species has been recorded both from the Øresund and the Bælt Sea (Jensen \& Spärck 1934).

Occurrence. The Boreal and Lusitanian regions.

Habitat. From the Intertidal zone down to $200 \mathrm{~m}$ deep 

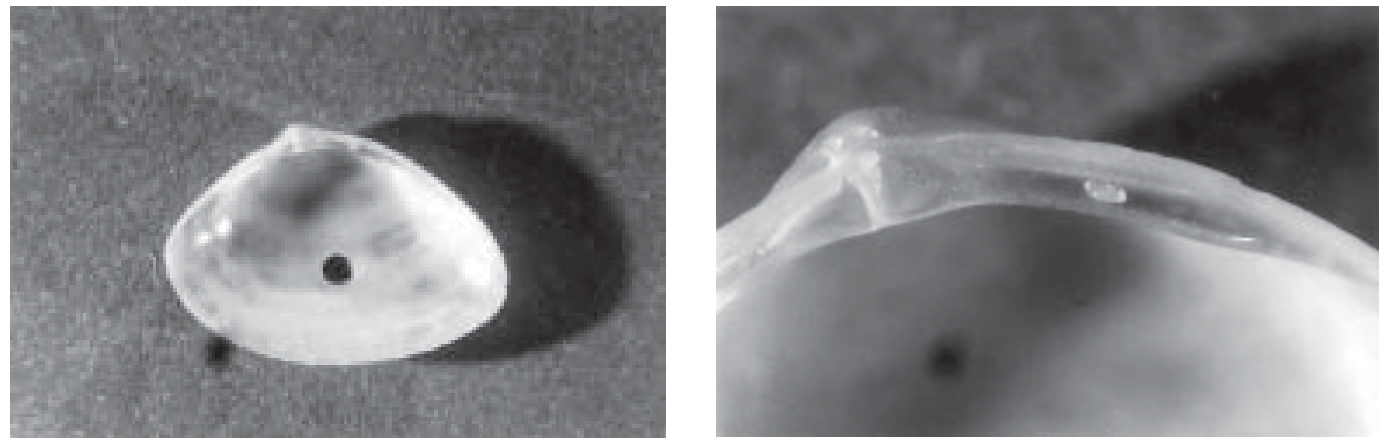

Fig. 70. a: Spisula subtruncata (da Costa 1778). Skagen 4, 15.0-15.5 m b.s., lab. no. 340,93. × 4.8. Right valve interior. MGUH 25380. b: Spisula subtruncata (da Costa 1778). Skagen 4, 15.0-15.5 m b.s., lab. no. 340,93. $\times 20$. Serrated surfaces of paired right valve laterals. MGUH 25380.

in mud and sand (Poppe \& Goto 1993). In Danish waters common at depths out to $20-30 \mathrm{~m}$ in sand (Jensen \& Spärck 1934).

Subfossil finds. The Bælt Sea, Limfjord, North Sea, Vendsyssel and Skagen regions, Holocene. From the Skagen Well recorded from the Atlantic, Subboreal and Subatlantic; in the Subatlantic occurring in huge quantities. From the Eemian recorded from the Brelt Sea, Baltic and Kattegat regions.

\section{Solecurtus chamasolen (da Costa 1778)}

Distribution. Norway off the Lofoten islands, and south to the Mediterranean. In the Danish waters shells have been found near Frederikshavn (Jensen \& Knudsen 1995).

Occurrence. The Boreal and Lusitanian regions.

Habitat. From 5 to 400 m deep on muddy bottoms.

Subfossil finds. None.

\section{Solecurtus scopula (Turton 1822)}

Distribution. From the British Isles and south to the Mediterranean. Shells recorded from the northern Kattegat (Jensen \& Knudsen 1995).

Occurrence. The Boreal and Lusitanian regions.

Habitat. Mainly offshore to $110 \mathrm{~m}$ deep in muddy sand and on clean gravel bottoms (Poppe \& Goto 1993).

Subfossil finds. None.

\section{Ensis americanus Gould 1870}

Distribution. At present occurring down to the Øresund. However, the species has recently accidentally been transported to western Europe from the east coast of North America (Jensen \& Knudsen 1995), so it will not be further considered.

\section{Ensis arcuatus (Jeffreys 1865)}

Distribution. The Faeroes, the British Isles and south to Spain. In Danish waters shells have been recorded from the Kattegat region, including the Øresund.

Occurrence. The Boreal and Lusitanian regions.

Habitat. From the intertidal zone to $40 \mathrm{~m}$ deep in sand and gravel bottoms.

Subfossil finds. None.

\section{Ensis ensis (Linnaeus 1758)}

Distribution. The Faeroes, Norway north of Lofoten, and south to the Mediterranean (Petersen 1968). The species extends from the North Sea east to the Limfjord and Kattegat regions, including the Øresund (Jensen \& Spärck 1934; Jensen \& Knudsen 1995).

Occurrence. The Boreal and Lusitanian regions.

Habitat. From the intertidal zone to about $80 \mathrm{~m}$ deep, burrowing in fine sand (Poppe \& Goto 1993). From the North Sea mainly recorded from depths of 20-30 $\mathrm{m}$ on the Dogger Bank and along the west coast of Jylland (Petersen 1977, fig. 40). 


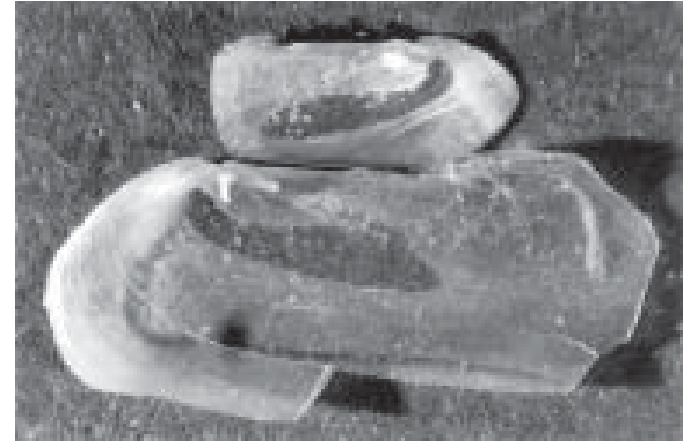

Fig. 71. Phaxas pellucidus (Pennant 1777). Skagen 4, 27.0-27.5 m b.s., lab. no. 352,93. $\times$ 9.6. View of the inside of a left valve above and a right valve below (valves not paired). MGUH 25381.

Subfossil finds. The Limfjord, North Sea and Vendsyssel areas, Holocene. During the Eemian recorded from the Bælt Sea, North Sea and the Vendsyssel regions.

\section{Ensis siliqua (Linnaeus 1758)}

Distribution. Norway from north of Lofoten, and south to the Mediterranean. In Danish waters, the species is recorded from the North Sea, Kattegat and Øresund (Jensen \& Spärck 1934).

Occurrence. The Boreal and Lusitanian regions.

Habitat. From the intertidal zone to about $70 \mathrm{~m}$ deep in fine sand.

\section{Subfossil finds. None.}

\section{Phaxas pellucidus (Pennant 1777)}

Fig. 71

Distribution. Norway off the Lofoten islands, and south to the Mediterranean (Madsen 1949). In Danish waters the species extends into the Limfjord and Kattegat, Øresund and Bælt Sea regions (Jensen \& Spärck 1934).

Occurrence. The Boreal and Lusitanian regions.

Habitat. Found offshore between 4 and $150 \mathrm{~m}$ deep in sand, mud and gravel bottoms (Poppe \& Goto 1993). In the North Sea it is abundant in the whole area, mainly from depths of 30-50 m (Petersen 1977).

Subfossil finds. The Limfjord, North Sea, Vendsyssel and Skagen regions, Holocene. From the Skagen Well recorded from the Subboreal and Subatlantic. During

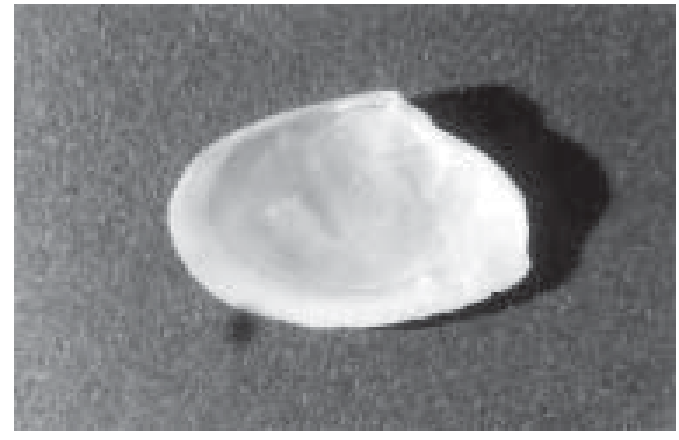

Fig. 72. Angulus tenuis (da Costa 1778). Skagen 4, 6.0-6.5 m b.s., lab. no. 331,93. $\times 4$.8. View of the inside of a right valve. MGUH 25382.

the Eemian found in the North Sea and Vendsyssel regions.

\section{Angulus tenuis (da Costa 1778)}

Fig. 72

Distribution. Norway off the Lofoten islands, and south to the Mediterranean (Madsen 1949). In Danish waters the species extends from the North Sea, where it is common in shallow waters, into the Kattegat and Limfjord regions (Jensen \& Spärck 1934).

Occurrence. The Boreal and Lusitanian regions.

Habitat. Common in shallow water down to 10-20 m deep in fine sand.

Subfossil finds. The Bælt Sea, Limfjord, North Sea, Vendsyssel and Skagen regions, Holocene. From the Skagen Well recorded from the Subatlantic. During the Eemian found in the Bælt Sea and North Sea regions.

\section{Arcopagia crassa (Pennant 1778)}

Distribution. From Norway south to West Africa. Only one record from Danish waters other than empty shells (Jensen \& Knudsen 1995).

Occurrence. The Boreal and Lusitanian regions.

Habitat. From the intertidal zone down to $150 \mathrm{~m}$ deep in sand, mud and shell gravel bottoms (Poppe \& Goto 1993).

Subfossil finds. None. 

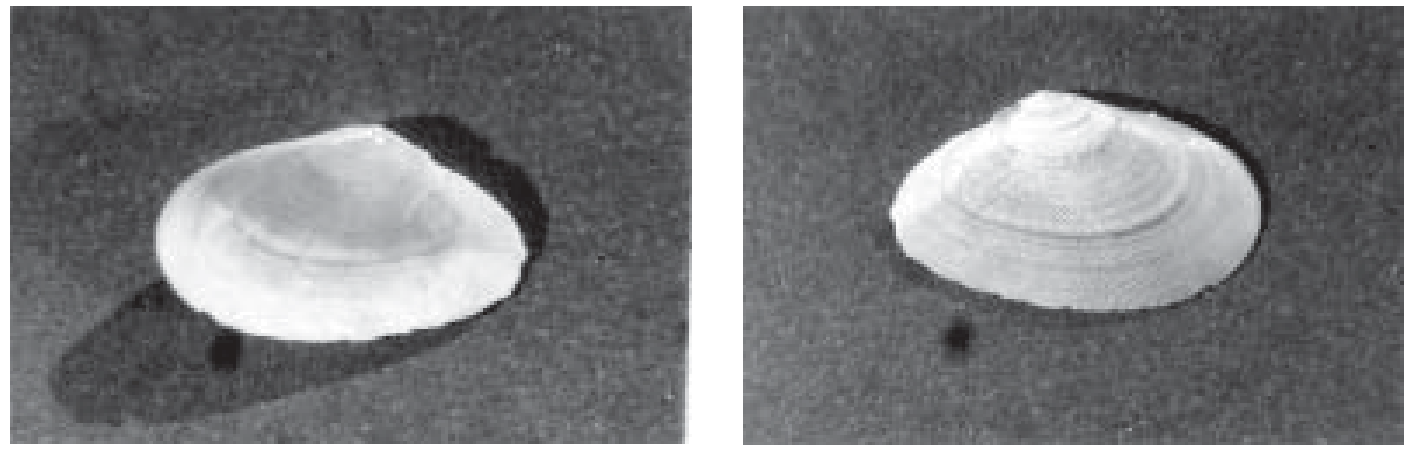

Fig. 73. a: Fabulina fabula (Gmelin 1791). Skagen 4, 6.0-6.5 m b.s., lab. no. 331,93. $\times$ 4.8. View of the inside of a right valve. MGUH 25383. b: $\times$ 4.8. Right valve exterior with diagonal lines running from the upper right to the lower left superimposed upon sculpture of concentric lines. MGUH 25383.

\section{Tellina donacina Linnaeus 1758}

Distribution. From the Shetlands over the British Isles and south into the Mediterranean (Poppe \& Goto 1993). The species occurs in the southern North Sea and has been recorded off Edinburgh (Jensen \& Spärck 1934).

Occurrence. The Boreal and Lusitanian regions.

Habitat. From the low-tide mark to $200 \mathrm{~m}$ deep in sand, mud and gravel bottoms.

Only subfossil finds. Recorded from the North Sea during the Eemian.

\section{Fabulina fabula (Gmelin 1791)}

Fig. $73 a, b$

Distribution. Norway of the Lofoten islands, and south to the Mediterranean (Madsen 1949). The species extends into Danish waters from the North Sea to the Kattegat and Limfjord regions (Jensen \& Spärck 1934).

Occurrence. The Boreal and Lusitanian regions.

Habitat. From the intertidal zone to $50 \mathrm{~m}$ deep in fine sand. In Danish waters common on sand between 5$25 \mathrm{~m}$, but it has been taken at depths of $40 \mathrm{~m}$ (Jensen \& Spärck 1934).

Subfossil finds. The Limfjord, North Sea, Vendsyssel and Skagen regions, Holocene. From the Skagen Well recorded from the Subatlantic. From the Eemian recorded from the North Sea.

\section{Tellina pygmaea (Lovén 1846)}

Fig. 74

Distribution. The Faeroes, Norway north of Lofoten, and south to the Mediterranean (Madsen 1949). The species extends from the North Sea into the Kattegat and Øresund (Jensen \& Knudsen 1995). Uncertain in the records from the Limfjord (Collin 1884, p. 113).

Occurrence. The Boreal and Lusitanian regions.

Habitat. From the intertidal zone to depths of $100 \mathrm{~m}$. In the North Sea found at depths of 30-50 m on hard bottoms (Petersen 1977).

Subfossil finds. From the Skagen Well recorded from the Subatlantic.

\section{Gastrana fragilis (Linnaeus 1758)}

Distribution. From the British Isles including the Shetlands, and south to the Mediterranean.

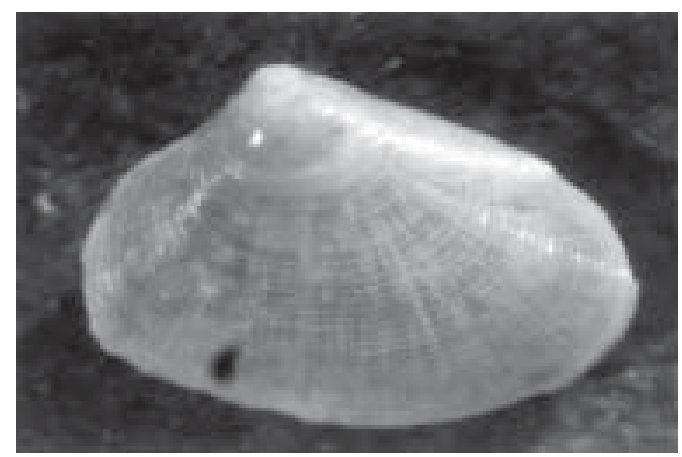

Fig. 74. Tellina pygmaea (Lovén 1846). Skagen 4, 27.0-27.5 m b.s., lab. no. 352,93. × 40. Right valve. MGUH 25384. 
Occurrence. Mainly the Lusitanian region.

Habitat. From below the tidal zone to a depth of 750 $\mathrm{m}$ in sand, mud and gravel bottoms (Poppe \& Goto 1993).

Subfossil finds. Recorded from the Bælt Sea, Kattegat and the North Sea during the Eemian.

\section{Macoma baltbica (Linnaeus 1758)}

Distribution. W Greenland, Norway from north of Lofoten, and south to the British Isles (Petersen 1968) and Spain (Poppe \& Goto 1993). The species is found in all the regions and extends far into the Baltic, but it is not common in the North Sea region from Blåvandshuk and north to Skagen (Jensen \& Spärck 1934).

Occurrence. The Subarctic, Boreal and Lusitanian regions.

Habitat. This is a shallow-water species, but in the Baltic occurs also at depths of more than $50 \mathrm{~m}$ on soft bottoms (Muus 1967, p. 163). The species is also the characterising animal of the Petersen Macoma balthica community so often found in the inner Danish waters. However, Muus (op. cit., pp. 215-217) discussed the problem concerning this community in further detail and concluded that Petersen's community can be considered a serviceable way of giving a brief description of a faunal region for other marine biologists.

Subfossil finds. The Bælt Sea, Baltic, Kattegat, Limfjord, North Sea and Vendsyssel regions, Holocene. Recorded from the Bælt Sea, Baltic, and the North Sea during the Eemian, and from the Vendsyssel area during the Late Weichselian.

\section{Macoma calcarea (Gmelin 1791)}

Distribution. W and E Greenland, Spitsbergen, around Iceland, the Faeroes, Norway from north of Lofoten (Madsen 1949), and south into the North Sea, Kattegat, Bælt Sea and Baltic (Jensen \& Spärck 1934).

Occurrence. The Arctic, Subarctic and Boreal regions.

Habitat. From the intertidal zone down to several hundred metres in the southern part of the distribution area. The species is the characteristic animal of the Arctic Macoma community (Thorson 1957).
Subfossil finds. From the Vendsyssel region, Holocene. Recorded from the Baltic and the Vendsyssel regions during the Eemian, from the Kattegat and Vendsyssel regions during the Early/Middle Weichselian (the Older Yoldia Sea stage), and finally from the Vendsyssel region also during the Late Weichselian (the Younger Yoldia Sea stage).

\section{Macoma torelli (Steenstrup) Jensen 1904}

Distribution. E and W Greenland and Spitsbergen. According to Ockelmann (1958) this species is regarded as having a high-Arctic main distribution and being restricted to the $\mathrm{N}$ Atlantic sector.

Occurrence. The Arctic region.

Habitat. Recorded rarely from Greenland sublittorally out to $90 \mathrm{~m}$ deep on clay and gravel (Ockelmann 1958).

Subfossil finds. Recorded from the Vendsyssel region during the Late Weichselian (the Younger Yoldia Sea).

\section{Macoma loveni (Steenstrup) Jensen 1904}

Distribution. W and E Greenland and Spitsbergen. According to Ockelmann (1958), the main distribution is high-Arctic with low-Arctic outposts.

Occurrence. The Arctic and Subarctic regions.

Habitat. At East Greenland the vertical range of the species has been recorded from 4-5 $\mathrm{m}$ to $207 \mathrm{~m}$, and the species has been taken from various types of bottoms: clay, mud, sand, gravel and stony ones (Ockelmann 1958).

Subfossil finds. The Vendsyssel region during the Late Weichselian (the Younger Yoldia Sea).

\section{Donax vittatus (da Costa 1778)}

Fig. 75

Distribution. Norway off the Lofoten islands, and south to the Mediterranean (Madsen 1949). This species is found on the southern part of the Dogger Bank and along the west coast of Jylland (Petersen 1977) but not in the inner Danish waters (Jensen \& Spärck 1934).

Occurrence. The Boreal and Lusitanian regions. 


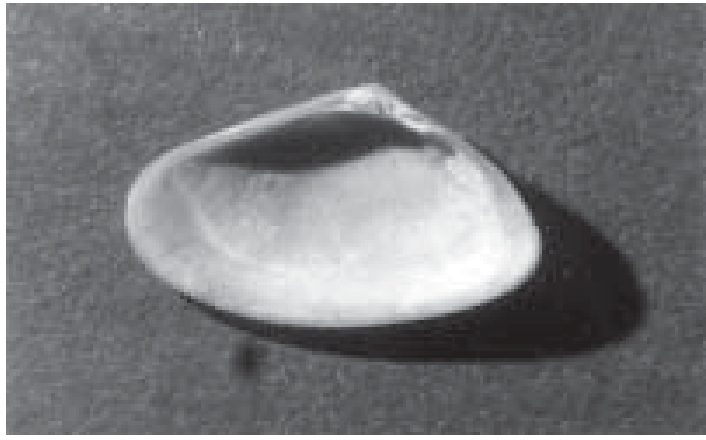

Fig. 75. Donax vittatus (da Costa 1778). GEUS collection. Holland. $\times 4.8$. View of the inside of a right valve. MGUH 25385

Habitat. From the tidal zone down to $20 \mathrm{~m}$ in clean sand. One of the few molluscan species well suited to live in the coastal zone of sandy beaches.

Subfossil finds. The Limfjord on old beach ridges facing the Skagerrak (Petersen 1976), North Sea, Vendsyssel and Skagen regions, Holocene. From the Skagen Well recorded from the Subatlantic. Found in the North Sea during the Eemian.

\section{Gari depressa (Pennant 1777)}

Distribution. Norway off the Lofoten islands, and south to the Mediterranean.

Occurrence. The Boreal and Lusitanian regions.

Habitat. From the intertidal zone down to about $50 \mathrm{~m}$ in sand, mud and gravel bottoms.

Subfossil finds. The Vendsyssel region, Holocene.

\section{Garifervensis (Gmelin 1791)}

Fig. 76

Distribution. W Greenland, the Faeroes, Norway north of Lofoten, and south to the Mediterranean (Petersen 1968). In the North Sea the species is most common on the Dogger Bank (Petersen 1977) and extends through the Skagerrak into the Kattegat and Øresund (Jensen \& Spärck 1934).

Occurrence. The Subarctic, Boreal and Lusitanian regions.

Habitat. From the tidal zone to a depth of $110 \mathrm{~m}$ in coarse sand and shell gravel bottoms (Poppe \& Goto

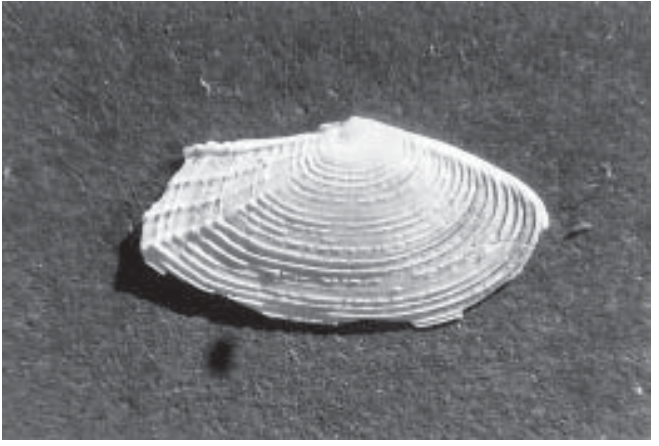

Fig. 76. Gari fervensis (Gmelin 1791). Skagen 4, 23.0-23.5 m b.s., lab. no. 348,93. × 4.8. Right valve. MGUH 25386.

1993). In Danish waters on mixed bottoms and sand at depths of 15-40 m (Jensen \& Spärck 1934).

Subfossil finds. The Limfjord, Vendsyssel and Skagen regions, Holocene. Recorded from the Subatlantic in the Skagen Well.

\section{Gari tellinella (Lamarck 1818)}

Distribution. S and W Iceland, the Faeroes, Norway north of Lofoten, and south to the Mediterranean. The species has been taken from the northern Kattegat (Jensen \& Knudsen 1995).

Occurrence. The Boreal and Lusitanian regions.

Habitat. From the intertidal zone to a depth of $460 \mathrm{~m}$ in coarse sand, gravel and stone bottoms.

Subfossil finds. None.

\section{Scrobicularia plana (da Costa 1778)}

Distribution. Norway off the Lofoten islands, and south to the Mediterranean (Madsen 1949). The species extends into the Bælt Sea at Kiel and Warnemünde (Jensen \& Spärck 1934), and is also recorded from the Limfjord (Petersen 1986a).

Occurrence. The Boreal and Lusitanian regions.

Habitat. From the intertidal zone to about $30 \mathrm{~m}$ in clay or muddy bottoms, often in estuaries (Poppe \& Goto 1993). Jensen \& Knudsen (1995) point to the occurrences in the Wadden Sea and to the sensitivity to severe winters, living in such shallow-water environments. 


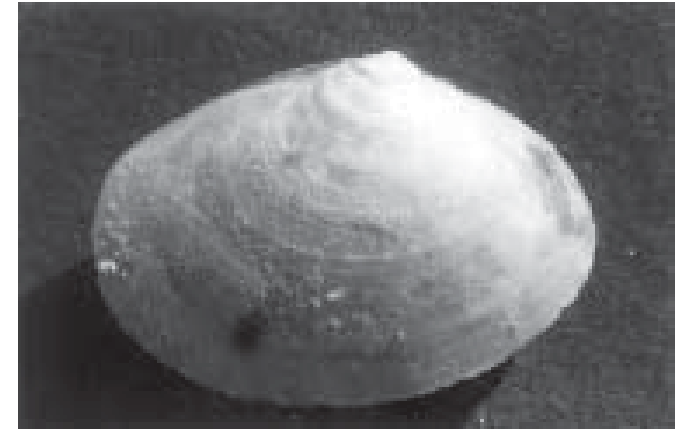

Fig. 77. Abra alba (Wood 1802). GEUS collection. Storebælt, Denmark. $\times$ 4.8. Specimen seen from the left. MGUH 25387.

Subfossilfinds. The Bælt Sea, Baltic, Kattegat, Limfjord, North Sea and Vendsyssel regions, Holocene. During the Eemian recorded from the Bælt Sea, Baltic, Kattegat, and North Sea regions.

\section{Abra alba (Wood 1802)}

Fig. 77

Distribution. Norway off the Lofoten islands, and south to the Mediterranean (Madsen 1949). In Danish waters it is found most abundantly in the shallow-water parts of the North Sea (Petersen 1977) and extends through the Skagerrak, Limfjord and Kattegat and Øresund into inner Danish waters such as the Bælt Sea and the Baltic to Neustadt, where it is the typical bottom animal (Jensen \& Spärck 1934).

Occurrence. The Boreal and Lusitanian regions.

Habitat. From the infralittoral zone to a depth of $65 \mathrm{~m}$ in sand, mud or muddy gravel (Poppe \& Goto 1993). In Danish waters common at depths of 3-8 $\mathrm{m}$ and out to 15-20 $\mathrm{m}$ in soft bottoms (Jensen \& Spärck 1934).

Subfossil finds. The Bælt Sea, Kattegat, Limfjord, North Sea, Vendsyssel and Skagen regions, Holocene. In the Skagen Well recorded from the Subboreal and Subatlantic. During the Eemian recorded from the Bælt Sea, North Sea and Vendsyssel regions.

\section{Abra nitida (Müller 1776)}

Fig. 78

Distribution. Recorded from S and W Iceland, the Faeroes, Norway north of Lofoten, and south to the Mediterranean (Madsen 1949). In Danish waters recorded from the North Sea, Skagerrak, Limfjord and Kattegat

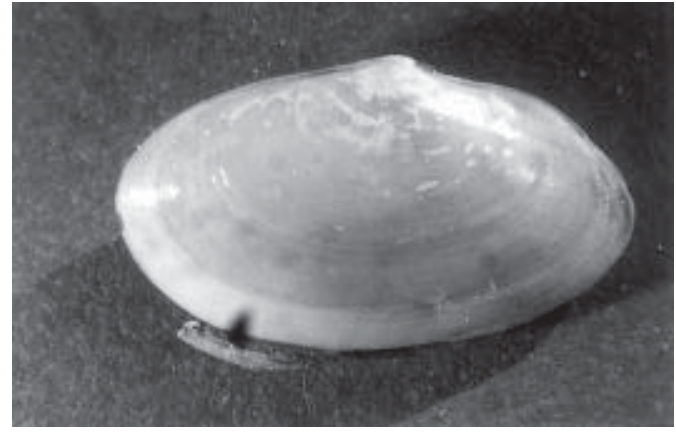

Fig. 78. Abra nitida (Müller 1776). GEUS collection. Hellebæk, Denmark. $\times$ 4.8. Specimen seen from the left. MGUH 25388.

(Jensen \& Spärck 1934), including the Øresund (Jensen \& Knudsen 1995).

Occurrence. The Boreal and Lusitanian regions.

Habitat. Mainly offshore to depths of $200 \mathrm{~m}$ in sandy mud, mud or gravel bottoms (Poppe \& Goto 1993). However, in Danish waters such as the North Sea on soft to mixed bottoms at depths of 40-70 m (Petersen 1977) and in the Skagerrak at depths of 100-300 m extending into the Kattegat, including the Øresund, on soft bottoms (Jensen \& Spärck 1934).

Subfossil finds. The Limfjord, North Sea, Vendsyssel and Skagen regions, Holocene. In the Skagen Well recorded from the Subboreal and Subatlantic. During the Eemian recorded from the Vendsyssel region.

\section{Abra prismatica (Montagu 1803)}

Fig. 79

Distribution. S and W Iceland, the Faeroes, Norway north of Lofoten, and south to the Mediterranean (Madsen 1949). In the Danish waters the species extends from the North Sea and Skagerrak into the Kattegat and Øresund (Jensen \& Knudsen 1995).

Occurrence. The Boreal and Lusitanian regions.

Habitat. From the infralittoral zone to $400 \mathrm{~m}$ deep in sand or muddy sand (Poppe \& Goto 1993). In the North Sea most abundant at depths deeper than $50 \mathrm{~m}$ on mixed bottoms (Petersen 1977).

Subfossil finds. The Limfjord, Vendsyssel and Skagen regions, Holocene. From the Skagen Well recorded from the Subboreal and Subatlantic. During the Eemian re- 


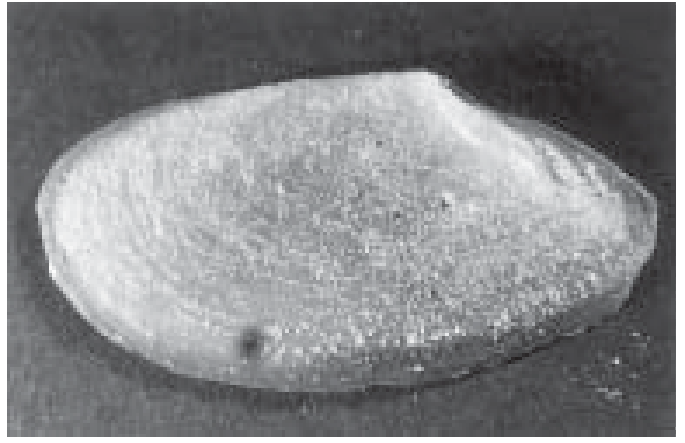

Fig. 79. Abra prismatica (Montagu 1803). GEUS collection. Iceland. $\times$ 4.8. Specimen seen from the left. MGUH 25389.

corded from the Brelt Sea, Kattegat, North Sea, and Vendsyssel regions.

\section{Abra segmentum (Récluz 1843)}

Distribution. From the west coast of France into the Mediterranean.

Occurrence. The Lusitanian region.

Habitat. In the infralittoral zone in sandy mud (Poppe \& Goto 1993). It seems to be connected with the shallow-water environment, also with brackish water (Jensen \& Spärck 1934).

Only subfossil finds. Recorded from the Bælt Sea and the North Sea during the Eemian.

\section{Arctica islandica (Linnaeus 1767)}

Fig. 80

Distribution. Around Iceland, the Faeroes, Norway

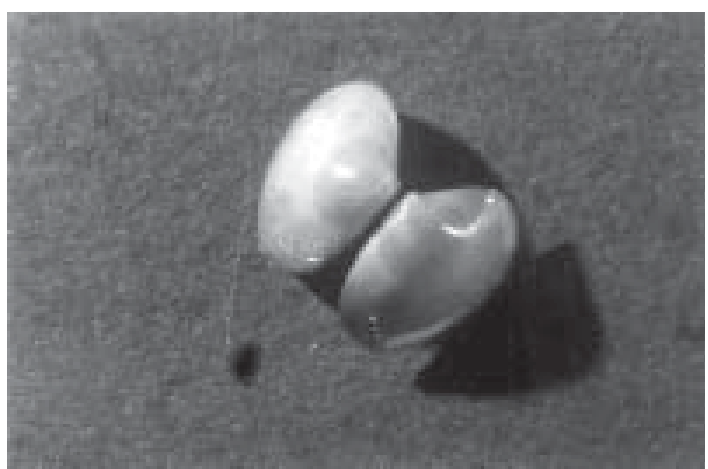

Fig. 80. Arctica islandica (Linnaeus 1767). GEUS collection. Læsø Rende, Denmark. $\times$ 4.8. Juvenile specimen, beaks directed forwards. MGUH 25390. north of Lofoten, and south to the Bay of Biscay. In the Danish waters, including the Limfjord, the species extends from the North Sea and Skagerrak as far as the Baltic (to Bornholm) (Jensen \& Spärck 1934).

Occurrence. The Subarctic, Boreal and (Lusitanian) regions. However, the species tends to live more deeply in the southern part of its range (Poppe \& Goto 1993).

Habitat. Intertidal to $482 \mathrm{~m}$ in mud, sand or gravel bottoms. In the North Sea mainly from depths deeper than $40 \mathrm{~m}$ and from mixed bottoms (Petersen 1977). In inner Danish waters often at depths from 10-15 to 50-60 on clay or clayey bottoms (Jensen \& Spärck 1934). According to Badarsson (1920), fishermen say that the species occurs in very shallow water, just below the low-water mark, in winter living deeply burrowed in the substrate, but in the summer often lying in abundance on the bottom.

Subfossilfinds. The Kattegat, Limfjord, North Sea, Vendsyssel and Skagen regions, Holocene. From the Skagen Well recorded in the Subatlantic. In the Bælt Sea, Baltic and North Sea (there are (single find) records from the Eemian and the Vendsyssel region during the Late Weichselian (the Younger Yoldia Sea).

\section{Kelliella miliaris (Philippi 1844)}

Fig. 81

Distribution. From Norway off the Lofoten islands, and south to the Mediterranean. From Danish waters recorded from the Skagerrak. According to Jensen \& Spärck (1934), very common in the deeper part of the Skagerrak. Jensen \& Knudsen (1995) mentioned a single finding from the southern Kattegat.

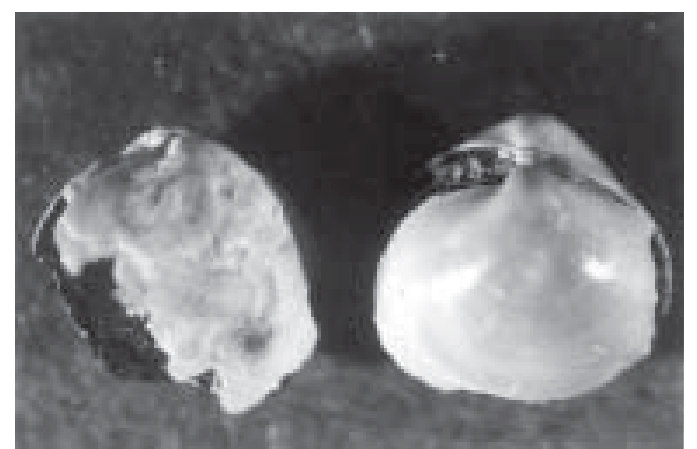

Fig. 81. Kelliella miliaris (Philippi 1844). Skagen 3, 185.04-185.06 m b.s., core sample-102. $\times 20$. Two specimens seen from the left. Inside the corroded specimen to the left, pyrite is seen. MGUH 25391. 
Occurrence. The Boreal and Lusitanian regions.

Habitat. From 134 to 700 m deep (Nordsieck 1969).

Subfossilfinds. Recorded from the Eemian in the Vendsyssel and Skagen regions.

\section{Glossus bumanus (Linnaeus 1758)}

Distribution. S and W Iceland, Norway off the Lofoten islands, and south to the Mediterranean. In Danish waters recorded from the North Sea and Kattegat, where shells are common (Jensen \& Knudsen 1995).

Occurrence. The Boreal and Lusitanian regions.

Habitat. Offshore beyond $7 \mathrm{~m}$ on bottoms of sand, sandy mud or soft mud (Tebble 1966).

Subfossil finds. None.

\section{Chamelea striatula (da Costa 1778)}

Fig. 82

Distribution. The Faeroes, Norway north of Lofoten, and south to the Mediterranean (Madsen 1949). In Danish waters the species extends from the North Sea, Limfjord and Skagerrak into the Kattegat and Øresund (Jensen \& Knudsen 1995).

Occurrence. The Boreal and Lusitanian regions.

Habitat. From the infralittoral zone to $55 \mathrm{~m}$ deep on sand and mud bottoms (Poppe \& Goto 1993). In the North Sea mainly from 20 to $40 \mathrm{~m}$ on sand to mixed bottoms (Petersen 1977). In the Skagerrak at depths of more than $100 \mathrm{~m}$, but in the Kattegat at depths of less

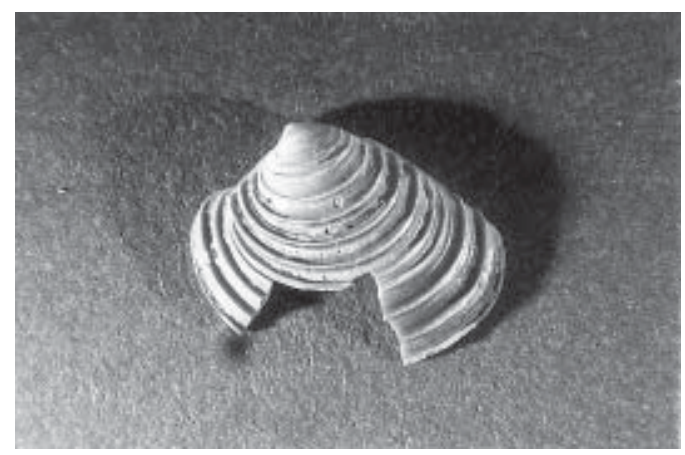

Fig. 82. Chamelea striatula (da Costa 1778). Skagen 4, 21.021.5 m b.s., lab. no. 346,93. × 4.8. Left valve. MGUH 25392. than $50 \mathrm{~m}$, since the sand bottom is not to be found at deeper levels (Jensen \& Spärck 1934).

Subfossil finds. The Limfjord, North Sea, Vendsyssel and Skagen areas, Holocene. From the Skagen Well recorded from the Subboreal and Subatlantic. During the Eemian recorded from the Bælt Sea, North Sea and Vendsyssel regions.

\section{Clausinella fasciata (da Costa 1778)}

Distribution. The Faeroes, Norway off the Lofoten islands, and south to the Mediterranean. From the North Sea the species extends into the Kattegat (Petersen 1888).

Occurrence. The Boreal and Lusitanian regions.

Habitat. From 4 to $110 \mathrm{~m}$ deep in sand, mud and gravel bottoms (Poppe \& Goto 1993). In the North Sea in hard sand (Petersen 1977), and in the Kattegat in gravel and sand between 15 and $30 \mathrm{~m}$ (Petersen 1888, p. 143).

Subfossil finds. The Limfjord, North Sea and Vendsyssel areas, Holocene.

\section{Papbia aurea (Gmelin 1791)}

Distribution. Norway off the Lofoten islands, and south to the Mediterranean. The finds closest to Danish waters are from southern Norway (Jensen \& Spärck 1934).

Occurrence. The Boreal and Lusitanian regions.

Habitat. From the tidal zone down to $36 \mathrm{~m}$ deep in sand, mud and gravel bottoms.

Only subfossil finds. The Bælt Sea, Kattegat, Limfjord, North Sea and Vendsyssel regions, Holocene. Recorded from the Kattegat region during the Eemian.

\section{Paphia aurea senescens (Cocconi 1873)}

Distribution. The only one of our Quaternary molluscs which does not live at present. Also found in Quaternary deposits in Italy (Jensen \& Spärck 1934). Regarded as a Lusitanian species according to Nordmann (1913). However, Poppe \& Goto (1993) regard the fossil valves found, for example along the coast of the Netherlands and Belgium, as a subspecies in which the differences 
from extant ones are minimal, and they propose that the relationship between the fossil and recent shells be restudied. From Nordmann (1913) and Cerulli-Irelli (1908) it seems right that Tapes senescens Doederl. and Tapes aureus var. eemiensis are identical. But as the relationship between $T$. senescens and T. aureus sensu stricto at the time of Nordmann (1913) was not clear, the position as a not extant subspecies given by Poppe and Goto is followed here.

Only subfossil finds. The Bælt Sea, Kattegat, and North Sea regions during the Eemian.

\section{Tapes decussatus (Linnaeus 1758)}

Distribution. Norway off the Lofoten islands, and south to the Mediterranean. Closest to Danish waters the species occurs off western Norway (Jensen \& Spärck 1934).

Occurrence. The Boreal and Lusitanian regions.

Habitat. From the tidal zone to a depth of few metres in sand or muddy-gravel bottoms.

Only subfossil finds. The Kattegat, Limfjord, North Sea and Vendsyssel regions, Holocene. Recorded from the North Sea region during the Eemian.

\section{Timoclea ovata (Pennant 1777)}

Fig. 83a, b

Distribution. S and W Iceland, the Faeroes, Norway north of Lofoten, and south to the Mediterranean (Madsen 1949). In Danish waters the species extends from the North Sea into the Kattegat and Øresund (Jensen \&
Knudsen 1995), but has not been recorded from the Limfjord (Petersen 1986a).

Occurrence. The Boreal and Lusitanian regions.

Habitat. At depths between 4 and $200 \mathrm{~m}$ on all types of bottoms (Poppe \& Goto 1993). In the North Sea usually deeper than $50 \mathrm{~m}$ and on soft bottoms (Petersen 1977).

Subfossil finds. The Limfjord, North Sea, Vendsyssel and Skagen regions, Holocene. In the Skagen Well recorded from the Subatlantic. During the Eemian found in the Bælt Sea, Kattegat and North Sea regions.

\section{Venerupis rbomboides (Pennant 1777)}

Distribution. The Faeroes, Norway off the Lofoten islands (Madsen (1949) does not mention any Norwegian occurrence), and south to the Mediterranean (Petersen 1968). One pair of united valves recorded from the northern Kattegat (Jensen \& Knudsen 1995).

Occurrence. The Boreal and Lusitanian regions.

Habitat. From the intertidal zone to $180 \mathrm{~m}$ deep (Poppe \& Goto 1993) in gravel and mud bottoms.

Subfossil finds. The Limfjord and Vendsyssel regions, Holocene.

\section{Venerupis pullastra (Montagu 1803)}

Distribution. Norway from north of the Lofoten islands, and south to the Mediterranean (Madsen 1949). From Danish waters recorded from the Limfjord and Katte-
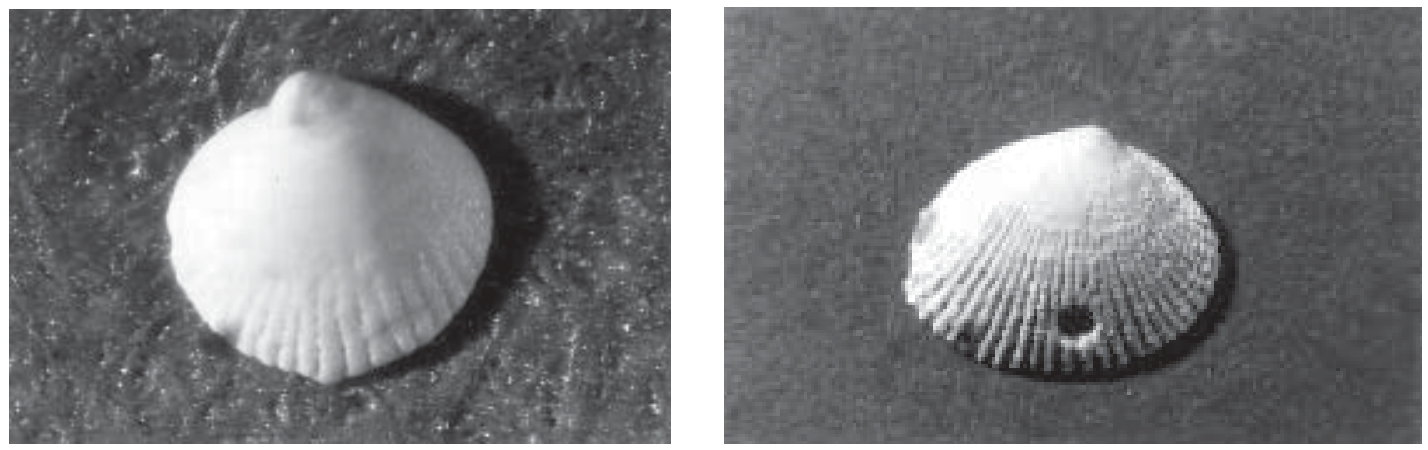

Fig. 83. a: Timoclea ovata (Pennant 1777). Skagen 4, 27.0-27.5 m b.s., lab. no. 352,93. × 40. Left valve. MGUH 25393. b: Timoclea ovata (Pennant 1777). GEUS collection. Herthas Flak, Denmark. × 4.8. Right valve. MGUH 25394. 
gat regions (Jensen \& Spärck 1934) and the Øresund (Jensen \& Knudsen 1995). The species has a common occurrence in the Isefjord (Rasmussen 1973).

Occurrence. The Boreal and Lusitanian regions.

Habitat. From the intertidal zone to $40 \mathrm{~m}$ deep in hard sand and muddy gravel (Poppe \& Goto 1993). Rasmussen (1973, p. 303): considers "its present common occurrence there [in the Isefjord] to be a result of the disappearance of the Zostera since 1933-45, as the lack of a continuous vegetation caused a change in the bottom conditions to the benefit of Venerupis pullastra. Undoubtedly the species has lived in interior Danish waters since the Stone Age, being, however, rare in recent times up to 1933-34".

Subfossilfinds. The Bælt Sea, Kattegat, Limfjord, North Sea and Vendsyssel regions, Holocene. Recorded from the North Sea region during the Eemian.

\section{Dosinia exoleta (Linnaeus 1758)}

Distribution. Norway off Lofoten, and south to the Mediterranean. The species extends from the North Sea (Petersen 1977) into the northern Kattegat (Jensen \& Knudsen 1995).

Occurrence. The Boreal and Lusitanian regions.

Habitat. From the intertidal zone to $73 \mathrm{~m}$ deep, burrowing deeply in sand, mud and gravel bottoms (Poppe \& Goto 1993). In the North Sea found at depths of 30$100 \mathrm{~m}$, on hard bottoms around the Dogger Bank (Petersen 1977).

Subfossil finds. The North Sea and Vendsyssel regions, Holocene.

\section{Dosinia lincta (Montagu 1803)}

Distribution. S and W Iceland, the Faeroes, Norway north of Lofoten, and south to the Mediterranean (Petersen 1968). The species extends from the North Sea into the Kattegat and Øresund (Petersen 1888).

Occurrence. The Boreal and Lusitanian regions.

Habitat. From the intertidal zone to $200 \mathrm{~m}$ deep in pure sand and fine gravel bottoms (Poppe \& Goto 1993). In the North Sea sampled at $10-100$ m on soft to mixed bottoms (Petersen 1977). From the Kattegat recorded on mixed bottoms between 18 and $56 \mathrm{~m}$ (Petersen 1888).

Subfossil finds. The North Sea and Vendsyssel regions, Holocene. Recorded from the Bælt Sea and the North Sea during the Eemian.

\section{Gouldia minima (Montagu 1803)}

Distribution. The Faeroes, Norway off the Lofoten islands, and south to the Mediterranean (Petersen 1968).

Occurrence. The Boreal and Lusitanian regions.

Habitat. From below the tidal zone to depths of over $200 \mathrm{~m}$ in sand, mud and fine gravel bottoms (Poppe \& Goto 1993).

Only subfossil finds. Recorded from the Brelt Sea and the North Sea during the Eemian.

\section{Petricola pholadiformis (Lamarck 1822)}

Distribution. This species in an immigrant introduced in to Europe, probably with oysters, at the end of the last century (Poppe \& Goto 1993). According to Jensen \& Knudsen (1995), the species occurred in 1906 in the Wadden Sea; the Skagerrak 1905; the Kattegat 1931; and the Bælt Sea 1943. It will not be considered any further in this work.

\section{Mysia undata (Pennant 1777)}

Distribution. The Faeroes, Norway north of the Lofoten islands, and south to the Mediterranean (Petersen 1968). In Danish waters the species extends from the North Sea (Petersen 1977) into the Kattegat and Øresund (Jensen \& Knudsen 1995). It is not recorded from the Limfjord (Petersen 1986a).

Occurrence. The Boreal and Lusitanian regions.

Habitat. From below the tidal zone to depths of $55 \mathrm{~m}$ in muddy sand and gravel bottoms (Poppe \& Goto 1993). In the North Sea found at depths of 40-70 m on soft to mixed bottoms (Petersen 1977).

Subfossil finds. The Limfjord and Vendsyssel regions, Holocene. During the Eemian recorded from the North Sea region. 


\section{Order Myoida}

\section{Mya arenaria Linnaeus 1758}

Distribution. Norway from north of the Lofoten islands, south to the British Isles (Petersen 1968). The species extends from the North Sea into the Limfjord and the inner Danish waters, including the Baltic (Jensen \& Spärck 1934). It is a late immigrant, known from Europe in the Plio-Pleistocene (Strauch 1972, pp. 135137) having been transferred from North America by man, presumably the Vikings, and dated back to the 13th century, i.e. well before Columbus (Petersen et al. 1992b).

Occurrence. Mainly in the Boreal region, but with new finds further to the south on the east coast of North America (Rasmussen \& Heard 1994).

Habitat. From the tidal zone down to 6-7 $\mathrm{m}$ deep in sandy bottoms, the species avoids high-energy coastal environments (Jensen \& Spärck 1934).

Subfossil finds. The records from the Brelt Sea and Vendsyssel might be of recent dates; only the occurrences at Jerup halfway up to the Skagen Spit have been dated and included in the Skagen area from the Subatlantic.

\section{Mya truncata Linnaeus 1758}

Distribution. W and E Greenland, Spitsbergen, around Iceland, the Faeroes, Norway from north of Lofoten, and south to the Bay of Biscay (Madsen 1949; Poppe \& Goto 1993). The species extends from the North Sea into the Limfjord and the inner Danish waters as far as the Bælt Sea (Kiel and Warnemünde) (Jensen \& Spärck 1934).

Occurrence. The Arctic, Subarctic, Boreal and Lusitanian regions.

Habitat. From the intertidal zone down to about $75 \mathrm{~m}$ deep (Poppe \& Goto 1993). However, in Danish waters often at depths between 10 and $20 \mathrm{~m}$ (Jensen \& Spärck 1934). In the North Sea found at depths of 37$70 \mathrm{~m}$ on soft mixed bottoms (Petersen 1977). In East Greenland the species belongs to the Arctic Macoma community (Ockelmann 1958). However, according to Jensen (1900) the typical Mya truncata is not found in the Arctic (G.H. Petersen, personal communication 1998).

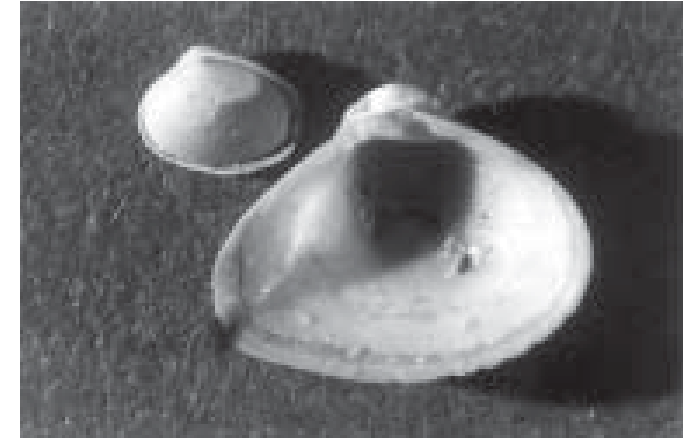

Fig. 84. Corbula gibba (Olivi 1792). Skagen 3, 37.00-37.25 m b.s., lab. no. 710,93. × 9.6. To the upper left a specimen seen from the left, and to the right a view of the inside of a right valve. MGUH 25395.

Subfossil finds. The Bælt Sea, Kattegat, Limfjord, North Sea and Vendsyssel regions, Holocene. Recorded from the Eemian in the Bælt Sea, Baltic, North Sea and Vendsyssel areas. From the Early/Middle Weichselian in the Kattegat and Vendsyssel regions, and from the Vendsyssel region also in the Late Weichselian.

\section{Corbula gibba (Olivi 1792)}

Fig. 84

Distribution. Norway north of Lofoten, and south to the Mediterranean (Petersen 1968). The species extends from the North Sea into the inner Danish waters, including the Limfjord, as far as the westernmost part of the Baltic region at Møn (Jensen \& Spärck 1934).

Occurrence. The Boreal and Lusitanian regions.

Habitat. From the low intertidal zone to $250 \mathrm{~m}$ deep anchored by a byssus on silty sand and muddy-gravel bottoms (Poppe \& Goto 1993). However, in Danish waters rarely at depths of more than about $50 \mathrm{~m}$ (Jensen \& Spärck 1934). In the North Sea sampled at 35-50 $\mathrm{m}$ depths on mixed bottoms (Petersen 1977).

Subfossil finds. The Bælt Sea, Baltic, Kattegat, Limfjord, North Sea, Vendsyssel and Skagen regions, Holocene. From the Skagen Well recorded from the Subboreal and Subatlantic. During the Eemian recorded from the Bælt Sea, Baltic, Kattegat, North Sea and Vendsyssel regions. 


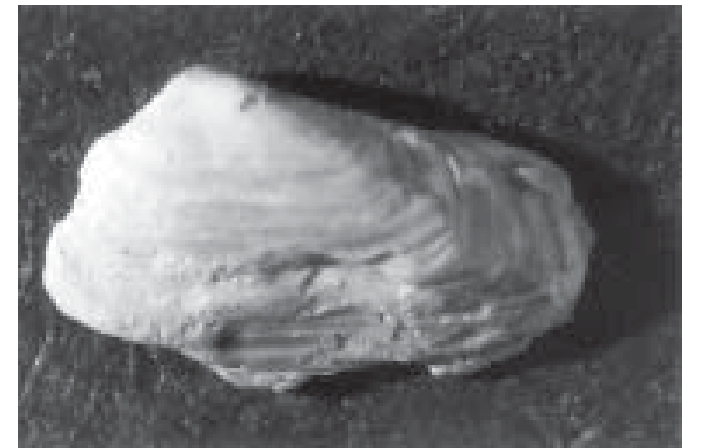

Fig. 85. Hiatella arctica (Linnaeus 1758). Skagen 3, 37.00-37.25 m b.s., lab. no. 710,93. × 20. Left valve. MGUH 25396.

\section{Hiatella arctica (Linnaeus 1758)}

Fig. 85

Distribution. W and E Greenland, Spitsbergen, around Iceland, the Faeroes, Norway from north of Lofoten, and south to the Mediterranean (Madsen 1949). Following Jensen \& Spärck (1934) who regard the records of Hiatella as one species, it is widely spread but not always common in all the Danish waters, it extends to Kiel in the Bælt Sea.

Occurrence. The Arctic, Subarctic, Boreal and Lusitanian regions.

Habitat. "From the intertidal zone down to almost 1400 $m$ fixed by its byssus on or in all kinds of substrate on all types of bottoms. Also found in holes previously bored by other species" (Poppe \& Goto 1993, p. 130). However, Petersen (1977, p. 228) states: "Both the systematics and nomenclature are insufficiently investigated for this genus". So with regard to the subfossil finds, the questions on species are even more difficult, as seen from Petersen (1986b, figs 2, 3), where forms with different habitat such as Hiatella cf. byssifera are found fixed on a stone taken as a grab sample in Kejser Franz Josephs Fjord, East Greenland, and as traces of Hiatella arctica in the Saxicava Sand of Late Weichselian age in Vendsyssel. However, here Símonarson et al. (1998) is followed, relating the more widely used and less specific name Hiatella arctica.

Subfossil finds. The Bælt Sea, Limfjord, North Sea, Vendsyssel and Skagen areas, Holocene. From the Skagen Well records from the Subboreal and Subatlantic. From the Eemian recorded from the Kattegat, North Sea, Vendsyssel and Skagen regions. In the Kattegat and Vendsyssel regions finds from the Early/Middle Weich- selian (the Older Yoldia Sea) and in the Vendsyssel region from the Late Weichselian (the Younger Yoldia Sea).

\section{Hiatella rugosa (Linnaeus 1758)}

Distribution. Jensen \& Knudsen (1995) include this as a separate species and take it as part of the recent Danish shell-bearing fauna. Records from the literature on subfossil finds are therefore considered here. According to Poppe \& Goto (1993), found from Norway south to the Mediterranean. Ockelmann (1958, p. 135 ff.), discussing the Hiatella taxonomy at some length, concludes that reservations must be made as to future separations of the Hiatella forms (H. arctica incl. of $H$. gallicana and $H$. pholadis) occurring in the northern hemisphere into valid species.

Occurrence. The Arctic, Subarctic, Boreal and Lusitanian regions.

Subfossil finds. The Kattegat and Vendsyssel regions, Holocene.

\section{Saxicavella jeffreysi Winckworth 1930}

Fig. 86

Distribution. Norway off the Lofoten islands, and south to the Mediterranean (Madsen 1949). The species extends into the Kattegat and Øresund, although rare (Jensen \& Knudsen 1995). It has been recorded from the Limfjord (Petersen 1986a).

Occurrence. The Boreal and Lusitanian regions.

Habitat. Offshore between 7 and $240 \mathrm{~m}$ deep in sand, mud or gravel bottoms (Poppe \& Goto 1993). In the

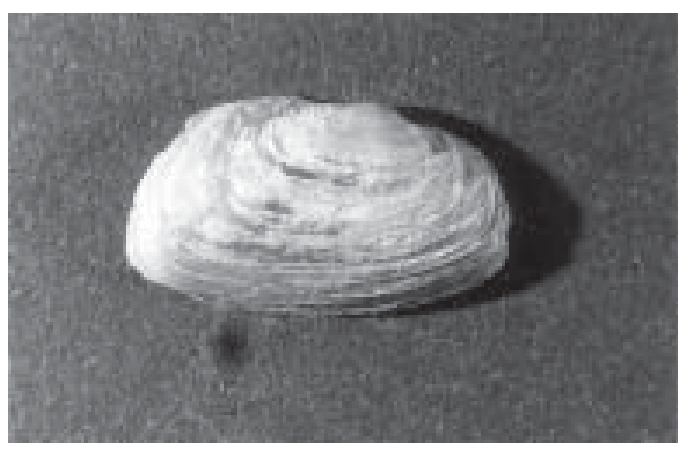

Fig. 86. Saxicavella jeffreysi Winckworth 1930. Skagen 4, 20.020.5 m b.s., lab. no. 345,93. × 4.8. Right valve. MGUH 25397. 
Danish waters often at depths between 25-50 m (Jensen \& Spärck 1934).

Subfossil finds. The Limfjord, North Sea, Vendsyssel and Skagen regions, Holocene. In the Skagen Well recorded from the Subatlantic. During the Eemian recorded from the North Sea region.

\section{Panomya arctica (Lamarck 1818)}

Distribution. S and W Iceland, Norway from north of Lofoten, and south to the British Isles and Denmark (Madsen 1949). However, Petersen (1968) refers to empty shells from $\mathrm{N}$ Iceland and occurrences in the Clyde Sea and off the Isle of Man. In Danish waters only once taken alive near Skagen, otherwise shells only, but found as far south as Øresund (Jensen \& Knudsen 1995).

Occurrence. Mainly Boreal, but outposts into the Subarctic (subfossil?) and Lusitanian regions (Strauch 1972).

Habitat. From the intertidal zone down to $300 \mathrm{~m}$ buried in mud or sand (Poppe \& Goto 1993).

Subfossil finds. None.

\section{Barnea candida (Linnaeus 1758)}

Fig. 87

Distribution. Norway off the Lofoten islands, and south to the Mediterranean (Madsen 1949). In the Danish waters, including the Limfjord, the species extends into the Bælt Sea as far as Kiel (Jensen \& Spärck 1934).

Occurrence. The Boreal and Lusitanian regions.

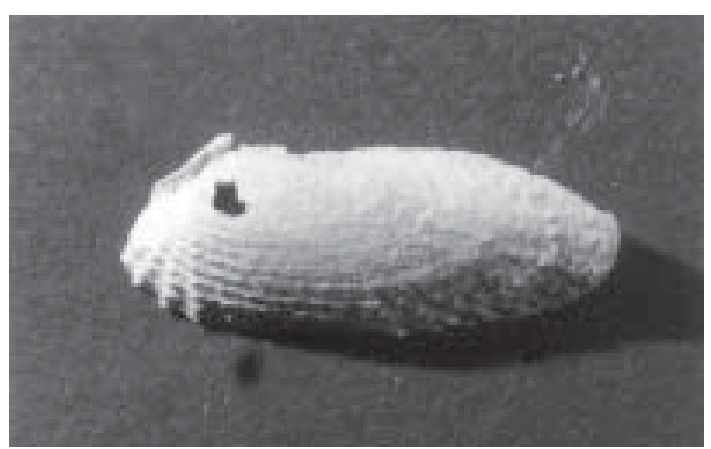

Fig. 87. Barnea candida (Linnaeus 1758). GEUS collection. Off Rubjerg Knude, Denmark. × 4.8. Left valve. MGUH 25398.
Habitat. From the low intertidal zone to about $30 \mathrm{~m}$ deep, the species bores in semi-hard substrates such as clay (Poppe \& Goto 1993).

Subfossilfinds. The Bælt Sea, Limfjord, North Sea, Vendsyssel and Skagen regions, Holocene. From the Skagen Well recorded from the Subatlantic. During the Eemian found in the Brelt Sea and North Sea regions.

\section{Pholas dactylus Linnaeus 1758}

Fig. 88a, b

Distribution. Norway off the Lofoten islands, and south to the Mediterranean (Madsen 1949). In Danish waters only found to Frederikshavn and the Limfjord (Petersen 1986a; Jensen \& Knudsen 1995).

Occurrence. The Boreal and Lusitanian regions.

Habitat. From the intertidal zone to a depth of $10 \mathrm{~m}$ boring in different substrates, preferring clay bottoms (Poppe \& Goto 1993).

Subfossil finds. The Limfjord, Vendsyssel and Skagen regions, Holocene. From the Skagen Well recorded from the Subatlantic.

\section{Zirfaea crispata (Linnaeus 1758)}

Distribution. Around Iceland, Norway from north of the Lofoten islands, and south to the Bay of Biscay (Madsen 1949). In the Danish waters, including the Limfjord, extending into the Bælt Sea as far as Kiel (Jensen \& Spärck 1934).

Occurrence. Mainly Boreal with outposts into the Lusitanian region.

Habitat. From the low tide line to about $7 \mathrm{~m}$ deep, boring in semi-hard substrates (Poppe \& Goto 1993). In the Danish waters the species has a wide extension, depending on the bottom substrates (Jensen \& Spärck 1934): In the North Sea and Skagerrak peat and chalk; in the Limfjord cementstone, Mo-clay, chalk, peat and clay; and the Bælt Sea clayey bottoms.

Subfossil finds. The Bælt Sea, Limfjord, North Sea and Vendsyssel regions, Holocene. From the Bælt Sea region recorded from the Eemian and from the Vendsyssel region during the Late Weichselian (the Younger Yoldia Sea). 

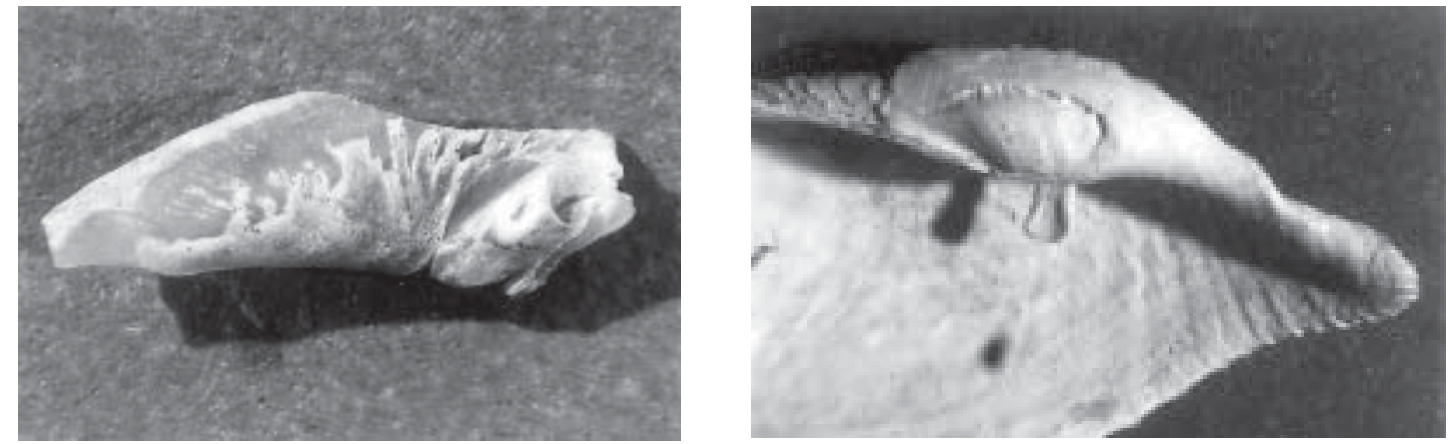

Fig. 88. a: Pholas dactylus Linnaeus 1758. Skagen 4, 20.0-20.5 m b.s., lab. no. 345,93. × 9.6 Fragment with umbonal reflection with septa. MGUH 25399. b: Pholas dactylus Linnaeus 1758.

\section{Xylophaga dorsalis Turton 1822}

Distribution. S and W Iceland, Norway from north of Lofoten, and south to the Mediterranean. Recorded from the Øresund region (Jensen \& Knudsen 1995).

Occurrence. The Boreal and Lusitanian regions.

Habitat. According to Madsen (1949) the occurrences at Iceland have been from depths between 140-230 m found in sunken pieces of wood.

Subfossil finds. None.

\section{Teredo navalis Linnaeus 1758}

Distribution. Norway off the Lofoten islands (Petersen 1968), and south to the Mediterranean (Madsen 1949). The species is found into the Brelt Sea (Jensen \& Spärck 1934).

Occurrence. The Boreal and Lusitanian regions.

Habitat. Specialised wood-borers.

Subfossil finds. None.

\section{Nototeredo norvegica (Spengler 1792)}

Distribution. S and W Iceland, Norway north of Lofoten, and south to the Mediterranean (Madsen 1949). The species extends from the North Sea (in driftwood) into the Bælt Sea as far as Kiel (Jensen \& Spärck 1934), and was recorded from the Limfjord by Collin (1884).

Occurrence. The Boreal and Lusitanian regions.
Habitat. In driftwood.

Subfossil finds. None.

\section{Psiloteredo megotara (Forbes \& Hanley 1848)}

Distribution. W Greenland, Spitsbergen, around Iceland, Norway north of Lofoten, and south to the Mediterranean (Madsen 1949). In Danish waters common on the west coast of Jylland and recorded from the Kattegat, including Øresund (Jensen \& Knudsen 1995).

Occurrence. The Arctic, Subarctic, Boreal and Lusitanian regions, although rare in the last region.

Habitat. Only in driftwood (Jensen \& Knudsen 1995).

Subfossil finds. None.

\section{Subclass Anomalodesmata Order Pholadomyoida}

\section{Pandora glacialis Leach 1819}

Distribution. W and E Greenland and Spitsbergen (Madsen 1949).

Occurrence. The Arctic and Subarctic regions.

Habitat. From 2 to $205 \mathrm{~m}$ deep on mixed bottoms (Ockelmann 1958).

Only subfossil finds. From the Vendsyssel region during Early/Middle and Late Weichselian (the Older Yoldia Sea and the Younger Yoldia Sea respectively). 

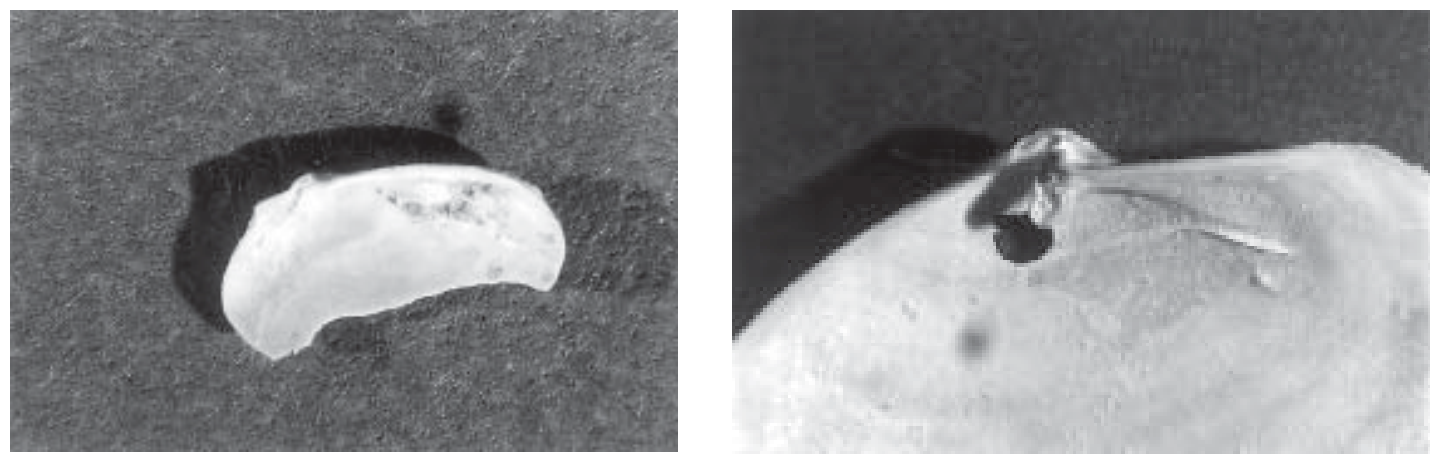

Fig. 89. a: Cochlodesma praetenue (Pulteney 1799). Skagen 3, 43.19-43.24, core sample-9. $\times 9.6$. View of the inside of a fragmented right valve. MGUH 25401. b: Cochlodesma praetenue (Pulteney 1799). GEUS collection. Læes $\emptyset$ Rende, Denmark. $\times$ 4.8. Detailed view of the inside of a right valve showing the resilifer. MGUH 25402.

\section{Lyonsia norwegica (Gmelin 1791)}

Distribution. S and W Iceland, the Faeroes, Norway off the Lofoten islands, and south to the Mediterranean. In Danish waters recorded from the Kattegat.

Occurrence. The Boreal and Lusitanian regions.

Habitat. From 20 to $250 \mathrm{~m}$ deep in sand, silty sand and mud bottoms.

Subfossil finds. Recorded from the Skagen region, Holocene. In the Skagen Well recorded from the Preboreal and Boreal.

\section{Lyonsia arenosa (Möller 1842)}

Distribution. W and E Greenland, Spitsbergen, and Norway north of the Lofoten islands. Main distribution in the Arctic and Subarctic regions.

Habitat. From 3 to about $200 \mathrm{~m}$ on mixed bottoms (Ockelmann 1958).

Subfossil finds. Recorded from the Vendsyssel region during the Early/Middle Weichselian and the Late Weichselian (the Older Yoldia Sea and the Younger Yoldia Sea respectively).

\section{Cochlodesma praetenue (Pulteney 1799)}

Fig. 89a, b

Distribution. S and W Iceland, the Faeroes, Norway off the Lofoten islands, and south to Gibraltar (Petersen 1968). The species is rare in Danish waters and has only once been taken live in the Kattegat (Jensen
\& Spärck 1934), although shells are found in the Øresund (Jensen \& Knudsen 1995).

Occurrence. The Boreal and Lusitanian regions.

Habitat. From the intertidal zone down to $110 \mathrm{~m}$ in sand, mud and gravel bottoms.

Subfossil finds. The North Sea and Skagen regions, Holocene. From the Skagen Well recorded from the Subatlantic. During the Eemian recorded from the Skagen region.

\section{Thracia convexa (Wood 1815)}

Distribution. The Faeroes, Norway off the Lofoten islands, and south to the Mediterranean (Madsen 1949). In Danish waters recorded from the Kattegat (Jensen \& Knudsen 1995).

Occurrence. The Boreal and Lusitanian zones.

Habitat. Offshore down to over $800 \mathrm{~m}$ in mud and sand bottoms (Poppe \& Goto 1993). In the Danish waters taken between 30-80 m (Jensen \& Spärck 1934).

Subfossil finds. None.

\section{Thracia phaseolina (Lamarck 1818)}

Fig. 90

Distribution. S and W Iceland, Norway off the Lofoten islands, and south to the Mediterranean (Madsen 1949). The species extends from the North Sea (Petersen 1977) into the Kattegat and Øresund, although with few records (Jensen \& Knudsen 1995), and it has been re- 


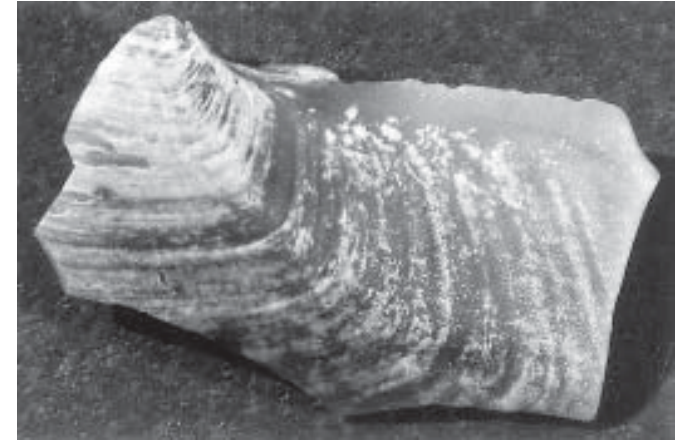

Fig. 90. Thracia phaseolina (Lamarck 1818). Skagen 4, 14.014.5 m b.s., lab. no. 339,93. × 9.6. Fragment of left valve. MGUH 25403.

corded from the Limfjord (Petersen 1986a).

Occurrence. The Boreal and Lusitanian regions.

Habitat. From the low intertidal zone down to $50 \mathrm{~m}$ in fine sand, mud or gravel bottoms (Poppe \& Goto 1993).

Subfossil finds. The Limfjord, North Sea, Vendsyssel and Skagen regions, Holocene. From the Skagen Well recorded from the Subatlantic. During the Eemian found in the Brelt Sea and North Sea regions.

\section{Thracia gracilis (Jeffreys 1865)}

Distribution. Recorded from the Atlantic (Nordsieck 1969). From the Danish waters found in the northern Kattegat (Jensen \& Knudsen 1995).

Occurrence. The Boreal and Lusitanian regions.

Subfossil finds. None.

\section{Thracia villosiuscula (MacGillivray 1827)}

Distribution. S and W Iceland, the Faeroes, Norway off the Lofoten islands, and south to the British Isles
(Petersen 1968). According to Poppe \& Goto (1993) also found in the Mediterranean.

Occurrence. The Boreal and Lusitanian regions.

Habitat. In the North Sea sampled at depths between 20 and $50 \mathrm{~m}$ on hard sand (Petersen 1977).

Subfossil finds. Recorded from the North Sea region during the Eemian.

\section{Cuspidaria cuspidata (Olivi 1792)}

Distribution. Norway off the Lofoten islands, and south to the Mediterranean. In the Danish waters found in the Kattegat (Jensen \& Spärck 1934) and Øresund (Jensen \& Knudsen 1995).

Occurrence. The Boreal and Lusitanian regions.

Habitat. From $20 \mathrm{~m}$ to $250 \mathrm{~m}$ deep in muddy sand and gravel bottoms (Poppe \& Goto 1993). In Danish waters at depths between 30 and $60 \mathrm{~m}$ (Jensen \& Spärck 1934).

Subfossil finds. None.

\section{Cuspidaria obesa (Lovén 1846)}

Distribution. E and W Greenland, Spitsbergen, around Iceland, Norway north of the Lofoten islands, and south to the Mediterranean; however, to the south only at depths greater than 400 m (Madsen 1949). In Danish waters recorded from the Skagerrak and Kattegat. Occurrence. The Arctic, Subarctic and Boreal regions.

Habitat. At depths from 40 to $2500 \mathrm{~m}$ according to Madsen (1949), but in Danish waters fairly common in the deeper part of the Skagerrak.

Subfossil finds. None. 